Board of Governors of the Federal Reserve System

International Finance Discussion Papers

Number 1098

March 2014

\title{
Are Long-Term Inflation Expectations Well Anchored in Brazil, Chile and Mexico?
}

\author{
Michiel De Pooter \\ Patrice Robitaille \\ Ian Walker \\ Michael Zdinak
}

NOTE: International Finance Discussion Papers are preliminary material circulated to stimulate discussion and critical comment. References to International Finance Discussion Papers (other than an acknowledgment that the writer has had access to unpublished material) should be cleared with the author or authors. Recent IFDPs are available on the Web at www.federalreserve.gov/pubs/ifdp. This paper can be downloaded without charge from the Social Science Research Network electronic library at www.ssrn.com. 


\title{
Are Long-Term Inflation Expectations Well Anchored in Brazil, Chile and Mexico?*
}

\author{
Michiel De Pooter ${ }^{\dagger}$ Patrice Robitaille ${ }^{\dagger} \quad$ Ian Walker Michael Zdinak
}

Federal Reserve Board of Governors

First draft: March 2013

This draft: March 2014

\begin{abstract}
In this paper, we consider whether long-term inflation expectations have become better anchored in Brazil, Chile, and Mexico. We do so using survey-based measures as well as financialmarket-based measures of long-term inflation expectations, where we construct the market-based measures from daily prices on nominal and inflation-linked bonds. This paper is the first to examine the evidence from Brazil and Mexico, making use of the fact that markets for longterm government debt have become better developed over the past decade. We find that inflation expectations have become much better anchored over the past decade in all three countries, as a testament to the improved credibility of the central banks in these countries when it comes to keeping inflation low. That said, one-year inflation compensation in the far future displays some sensitivity to at least one macroeconomic data release per country. However, the impact of these releases is small and it does not appear that investors systematically alter their expectations for inflation as a result of surprises in monetary policy, consumer prices, or real activity variables. Finally, long-run inflation expectations in Brazil appear to have been less well anchored than in Chile and Mexico.
\end{abstract}

Keywords: Inflation targeting, survey expectations, inflation compensation, Nelson-Siegel model, macro news suprises, Brazil, Chile, Mexico

JEL classification: D84, E31, E43, E44, E52, E58, G14

${ }^{*}$ We thank Refet Gürkaynak, Andrew Levin, Jonathan Wright, participants at the 2013 Research Conference of the International Journal of Central Banking in Warsaw and the 2013 LACEA Meeting in Mexico City, and seminar participants at the Federal Reserve Board and the Bank of Mexico for very helpful comments. We also thank RiskAmerica for kindly providing us with data on Chilean bond yields and Proveedor Integral de Precios for data on Mexican bond prices. The views expressed in this paper are solely the responsibility of the authors and should not be interpreted as reflecting the views of the Board of Governors of the Federal Reserve or of any other employee of the Federal Reserve System.

${ }^{\dagger}$ Corresponding authors. Board of Governors of the Federal Reserve System, Washington, D.C. 20551; US. Tel.: (202) 452-2359. E-mail addresses: michiel.d.depooter@frb.gov (M. De Pooter), patrice.robitaille@frb.gov (P. Robitaille), ian.a.walker@frb.gov (I. Walker), michael.g.zdinak@frb.gov (Michael Zdinak). 


\section{Introduction}

Nearly 30 countries have adopted inflation-targeting frameworks, driven by a conviction that defining an explicit inflation target and communicating how the central bank will strive to meet that goal is the best monetary policy strategy for maintaining inflation at a relatively low and stable level without sacrificing long-term growth. ${ }^{1}$ Nonetheless, it is still an open question whether countries that have adopted inflation-targeting regimes have lower inflation and better economic performance than countries that follow other monetary frameworks, see for example the research on macroeconomic performance in Ball (2011), Ball and Sheridan (2005), Gonçalves and Salles (2002), and Brito and Bystedt (2010). Others have taken a different approach by looking for evidence on the extent to which inflation expectations are well anchored using survey and financial market data. Because of data limitations, however, most of the latter work has focused on the experience of industrialized countries. In this study, we overcome some of these data problems for developing countries and explore whether, and to what degree, long-term inflation expectations are well anchored in three emerging market economies: Brazil, Chile, and Mexico.

The behavior of long-term inflation expectations provides insight into the success of inflation targeting as a monetary policy strategy. Emerging market economies (EMEs) tend to be subject to particularly large and frequent disturbances to the economy (Fraga, Goldfajn, and Minella, 2004), and these disturbances at times can drive inflation away from the target. Furthermore, monetary policy influences inflation with a considerable lag and there is uncertainty about the transmission process itself. These circumstances will influence inflation expectations over the short- and mediumterm. But if the central bank is viewed as being credibly committed to bringing inflation back to the inflation goal, shocks that affect inflation should be viewed as transitory and should therefore not influence long-term inflation expectations.

Although most studies compare inflation-targeting countries with non-inflation-targeting countries, inflation-targeting countries often practice very different policies. Hence, we believe it is informative to consider within-group differences by comparing the experiences of Brazil, Chile, and Mexico. These three Latin American countries adopted inflation-targeting frameworks over a decade ago and are similar in at least two other respects: They are at comparable stages of development and have a historical record of monetary and fiscal mismanagement and high inflation. However, there are also differences among the three with respect to institutional settings and in how their central banks explain to the public how they will strive to achieve the inflation goal. Chile, for example, had already achieved considerable success in macroeconomic stabilization in

\footnotetext{
${ }^{1}$ According to Hammond (2012), 27 countries are considered to have inflation-targeting frameworks: Armenia, Australia, Brazil, Canada, Chile, Colombia, the Czech Republic, Ghana, Guatemala, Hungary, Iceland, Indonesia, Israel, Korea, Mexico, New Zealand, Norway, Peru, the Philippines, Poland, Romania, Serbia, South Africa, Sweden, Thailand, Turkey, and the United Kingdom. Many observers would also add the euro area to this list.
} 
the 1980s. The Central Bank of Brazil (CBB) is not legally independent, which has at times raised questions about its ability to fulfill its inflation-targeting mandate without political interference. Several years after the Bank of Mexico (BOM) adopted its inflation-targeting framework, it had continued to formally target a money aggregate and, unlike most other inflation-targeting central banks, did not publish its inflation forecasts, see Batini and Laxton (2006). ${ }^{2}$

Our approach is a blend of a formal and informal analysis. In our formal analysis, we follow the approach that was first used by Gürkaynak, Levin, Marder, and Swanson (2007a) by examining evidence from financial-market-derived measures of long-term inflation expectations. Long-horizon financial-market-based expectations of future inflation with a sufficiently long history have been unavailable to date for Brazil and Mexico (and somewhat less so for Chile) as a result of insufficient historical data on local-currency-denominated sovereign bond prices. Therefore, we first collected a comprehensive set of historical prices on nominal and inflation-linked sovereign bonds for Brazil and Mexico - the Chilean data were provided to us by RiskAmerica - and used these prices to construct daily far-forward inflation compensation estimates for each country, as we detail below. We exploit the fact here that over the past decade, bond markets in Brazil and Mexico have made remarkable strides in terms of depth and liquidity, which allows us to construct these types of high-frequency market-based measures.

Inflation compensation provides a reading on investors' expectations for inflation plus the premium that investors demand for the risk that inflation may exceed its expected level. ${ }^{3}$ Far-forward inflation compensation covers a period that is several years in the future, beyond the period over which transitory shocks typically influence macroeconomic activity. In our informal analysis, we compare far-forward inflation compensation with long-term inflation expectations derived from Consensus Economics' survey data. We can compare the two measures to assess whether they convey differences in the degree to which countries' inflation-targeting frameworks are successful in shaping agents' expectations about future inflation.

Similar to Gürkaynak et al. (2007a) and Gürkaynak, Levin, and Swanson (2010a), among others, we then assess whether our market-based measures of far-forward inflation compensation respond significantly to domestic news surprises in monetary policy decisions, consumer prices, and real activity data releases. We also consider whether inflation compensation in these countries is sensitive to news from the United States and China. We consider China because of its increasing importance over the past decade as an export destination for Brazil and Chile.

\footnotetext{
${ }^{2}$ Between the late 1990s and 2008, the BOM formally followed an operating procedure that is known as 'el corto' and which is similar to targeting non-borrowed reserves, see below, as well as Ramos-Francia and Torres-García (2005).

${ }^{3}$ Hördahl (2009) notes besides reflecting these two factors, inflation compensation also reflects liquidity premia and "technical" market factors. While we do not explicitly take these items into account in our baseline regression analysis in Section 4.1, we do consider controlling for them in a sensitivity analysis to our baseline results, see Appendix A.
} 
Gürkaynak et al. (2010a) found that long-term inflation expectations were better anchored in Sweden, an inflation-targeting country, than in the United States, which at the time did not have an explicit inflation target in place. Far-forward inflation compensation for Sweden did not react significantly to news suprises during a period from 1996 to 2005, while U.S. forward inflation compensation did react significantly to surprises during a very similar period (1998 to 2005). These authors also found that long-term inflation expectations in the United Kingdom became well anchored after the Bank of England gained legal independence in the late 1990s. Gürkaynak et al. (2007a) compare the experience of the United States with those of Canada and Chile, using data for somewhat different periods for each country. Long-term inflation expectations were found to be well anchored in Canada and Chile, although the evidence for Chile is based on a short sample period (2002 to 2005). Details on this empirical approach are in Section 4. Galati, Poelhekke, and Zhou (2011) explored whether the global financial crisis unhinged long-term inflation expectations. Although the evidence is inconclusive, long-term inflation expectations in the United Kingdom drifted up.

These studies have nearly all focused on the experience of industrialized economies, as marketbased measures of long-term inflation expectations have been unavailable to date for many emerging market economies. That long-term bond markets in Brazil, Chile, and Mexico have developed rapidly over the past decade now allows us to construct our financial-market-based inflation compensation measures. Although market liquidity problems for some long-term bonds in these countries will still certainly pose an issue, we believe it is well worth taking a closer look at what the results from the event-study analysis imply.

Overall, we find that inflation expectations have become much better anchored over the past decade in all three countries, which is a major achievement, considering these countries' highinflation past. That said, survey-based and financial-market-based readings on the long-term inflation outlook have been consistently above the target in Brazil and Mexico, but more so in Brazil. Moreover, although we do not find evidence that market participants systematically revise their views about long-term inflation in response to domestic macroeconomic and monetary policy news, one-year inflation compensation in the far future displays some sensitivity to at least one macroeconomic data release in each country. New information appears to prompt market participants to revise either their expectations on inflation directly or their assessment of risks to the inflation outlook more generally. Revisions are relatively small, however. Far-forward inflation compensation for Mexico is sensitive to U.S. nonfarm payrolls data, likely reflecting both the tight linkages between the two economies and the fact that important Mexican macroeconomic data are released with a considerable delay. Far-forward inflation compensation in Brazil, but not in Chile, exhibits some sensitivity to data releases from China. Finally, evidence from both financial markets and survey data suggest that long-run inflation expectations have been less well anchored in Brazil than 
in Chile and Mexico.

As in all empirical studies that look at the response of financial market variables to economic news, the explanatory power of our regressions is quite low. Although in our case this result is consistent with the null hypothesis that inflation expectations have become better anchored, the volatility in some of our inflation compensation measures indicates that it may simply be that other types of news that we are not able to capture in our regressions have been important drivers of long-term inflation expectations and inflation risk premia for these countries.

\section{Inflation Targeting in Brazil, Chile, and Mexico}

\subsection{Inflation Targeting in Brazil, Chile, and Mexico}

Brazil, Chile, and Mexico adopted inflation-targeting frameworks after having previously experimented with alternative monetary policy strategies. Brazil adopted an inflation-targeting framework in 1999 after abandoning a fixed exchange rate policy in the midst of a currency crisis. In Chile, the Central Bank of Chile (CBC) had begun to set annual inflation targets in the early 1990s. However, a "full-fledged" inflation-targeting framework was put into place in 1999, when, upon floating the Chilean peso in September of that year, the CBC announced that it would implement an inflation-targeting framework and that the inflation target range would be 2 to 4 percent beginning in 2001, see Valdés (2007). In 2007, the inflation target was set at 3 percent within a 2 to 4 percent tolerance range.

In Mexico, after abandoning its fixed exchange rate policy in December 1994, the BOM, in search of a new nominal anchor, adopted a money target. However, the BOM found that money demand was too unstable for money targets to be an effective means of controlling inflation. By 1998, the BOM's monetary policy announcements could be seen as signaling the direction in which the central bank wanted interest rates to move (Ramos-Francia and Torres-García, 2005). In 1999, BOM officials wrote that Mexico's monetary policy framework was "in a transition period towards a clear-cut inflation targeting scheme." (Carstens and Werner, 1999; cited in Mishkin and Savastano, 2001). The BOM formally adopted its inflation-targeting framework in 2001 and announced that the inflation target would be 3 percent beginning in 2003.

Reflecting a growing consensus that central banks need to be free from political pressures to pursue short-term objectives, the central banks of Chile and Mexico had been granted legal autonomy with price stability as their primary mandate, Chile in 1990 and Mexico in 1994. In Brazil, in the absence of formal legal independence for the CBB, the law that laid out the basic features of the inflation-targeting framework delegated the central bank with the responsibility of pursuing the target, which in effect meant that the CBB had sole control over targeting the Selic rate as its key monetary policy instrument. Steps were also taken in all three countries to 
strengthen public finances. Authorities enacted reforms in the financial sector and other areas to reduce vulnerabilities to financial turmoil.

Nonetheless, in Brazil, the early years of inflation targeting were marked by sharp disagreements over the macroeconomic policy framework between the party then in power-that of Henrique Cardoso of the Brazilian Social Democratic Party (the PSDB) - and the main opposition partythe left-leaning Worker's Party (the PT). By mid-2002, Brazil was in the throes of a financial crisis which was fueled by investor worries that the leading presidential candidate, Luiz Incio da Silva (widely known as Lula) of the PT, would abandon the macroeconomic policies of his predecessor. The Lula government, which took office in January 2003, addressed these concerns by taking steps to demonstrate its commitment to fiscal and monetary conservatism, including appointing Henrique Meirelles, a prominent banker, as central bank president.

Whether Brazil's inflation target represents policy makers' views on the appropriate level of inflation that is independent of macroeconomic conditions appears to be an open question. The inflation target for 2003 was gradually reduced to a low of $3 \frac{1}{2}$ percent. (Since 2000, the inflation targets have been set each year a year and a half in advance.) Former CBB President Arminio Fraga, who had presided over the introduction of the inflation-targeting framework, relates that "... [d] uring the initial phase, a gradual and declining path for inflation was defined with the aim of bringing inflation to the desired level. At that moment, we imagined that such level would be, in a first step, something close to 3 to 4 percent (inspired by the Chilean experience) and that, with time, we would go to a rate close to the world average" (Fraga, 2009, the translation is ours).

After the Lula government took office, the inflation target was set at $4 \frac{1}{2}$ percent in mid-2003 and the target has remained at that level since then. However, in 2004, CBB President Meirelles stated that he envisioned inflation falling to a long-term inflation target of 4 percent (Gomes, 2004). In mid-2007, in announcing the target for 2009, Finance Minister Guido Mantega stated that "the inflation targets for 2008 and 2009 should be seen as a transition in the direction of a long-term inflation target that I judge appropriate to be in the neighborhood of 4 percent, given the characteristics of the Brazilian economy" (Goldfajn, 2007, the translation is ours).

Dilma Rousseff, Lula's protege and successor, took office in January 2011, and appointed Alexandre Tombini as the new central bank president. In October 2012, Tombini stated that "[w]e have to have the ambition of having inflation converge to [inflation] of our trading partners, as this, in the medium and long-term, would make a difference. Nonetheless, at the moment, we have to consolidate this level [referring to the $4 \frac{1}{2}$ percent inflation target]." (Grinbaum, 2012, the translation is ours.). As we detail below, there is some evidence that uncertainty about the longer-term inflation goal has been feeding into survey and financial market-based readings on the longer-term inflation outlook for Brazil.

The top panels of Figures 1 through 3 show 12-month headline inflation in Brazil, Chile, and 
Mexico (the thick black lines), as well as the inflation target and the tolerance range for each country's inflation target from January 2001 to April 2013. ${ }^{4}$ The thin lines, which depict measures of core inflation, illustrate the heavy influence of food and energy prices on the headline CPIs. ${ }^{5}$ Considering their inflation records, inflation has been remarkably low in each country, remaining in single-digit range since the early 2000s in Brazil and Mexico and only briefly going into double-digit range in Chile.

\section{Survey and Market-Based Measures of Inflation Expectations}

\subsection{Survey-Based Inflation Expectations}

The middle panels of Figures 1 through 3 compare each country's inflation target between January 2001 and April 2013 to long-term expected inflation from the semi-annual Consensus Forecasts survey, using the average forecast across respondents. This survey, which is conducted by Consensus Economics in April and October of each year, polls analysts' expectations of average annual inflation six to ten years in the future. Using Consensus Forecasts data, Levin, Natalucci, and Piger (2004) document that long-term inflation expectations had already been declining in the years preceding the adoption of inflation targets in inflation-targeting EMEs for which survey data was available. ${ }^{6}$

Average expected inflation for Chile, shown in Panel B of Figure 2, has been very close to 3 percent. A drawback of the long-term Consensus forecasts for these countries is the low number of survey participants. Only 8 to 12 panelists have been providing long-term forecasts, about half of the number of participants in Consensus Forecasts' monthly survey of short- and medium-term forecasts. ${ }^{7}$ Alternatively, the three central banks also conduct their own surveys of expectations on the macroeconomy with a larger number of participants. Plotted in Panel B is the median expectation for 12-month inflation ending 23 months in the future from the CBC's monthly survey of forecasters. ${ }^{8}$ The median expectation strayed from the target during the run-up in inflation in 2008, but otherwise has been close to the 3 percent target. Long-term inflation expectations for

\footnotetext{
${ }^{4}$ Panel A of Figure 1 shows only the initial target for Brazil, that is, the target that is announced a year and a half in advance. Between 2002 and 2005, the targets were adjusted upwards to accommodate for unforseen and adverse supply-side shocks.

${ }^{5}$ For Brazil, the core inflation measure shown excludes food and fuel for vehicles and home use. Together, these items have about a 16 percent weight in the headline index. For Chile, core inflation is the CPIX, which excludes fuels, fresh fruits, and vegetables. These items have a weight of about 9 percent in the headline CPI. Core inflation for Mexico excludes fruits and vegetables, meat and eggs, and energy and other government-regulated prices. These items have a 25 percent weight in the headline CPI.

${ }^{6}$ Levin et al. (2004) do not report results for Chile because long-term inflation expectations were first surveyed in the mid-1990s and because they date Chile's adoption of an inflation target to 1991. Long-term inflation expectations for Chile also declined over the 1990s.

${ }^{7}$ Private communication with Steven Hubbard, Manager, Consensus Economics, September 25, 2013.

${ }^{8}$ This is the longest forecast horizon that the CBC polls forecasters on because the CBC aims to bring inflation to the 3 percent target within two years.
} 
Mexico have been at or very near three and a half percent since 2005, $\frac{1}{2}$ percentage point above the target, in the Consensus Forecasts survey as well as in the BOM's monthly survey of analysts' expectations, which began in 2008 (the solid blue line in Panel B of Figure 3). The BOM surveys about 30 private-sector analysts about their views on average inflation five to eight years in the future and reports the average expectation from this survey.

For Brazil, long-term inflation expectations have been more variable but far less so than headline inflation. Note that the scales across Figures 1 - 3 differ: the range for Brazil is twice that for Chile and Mexico. The average long-term inflation expectation for Brazil rose during the 2002-03 crisis, fell below the $4 \frac{1}{2}$ percent target in the years following the crisis, and in 2007 began to drift up. This pattern can be see more clearly in Panels A and B of Figure 4, which plot the average and median expectations of medium- to long-term inflation from the CBB's weekly survey of professional forecasters. The chart plots the forecast that is furthest in the future at the time of the survey, which is the one that is four calendar years ahead. By the end of our sample period (April 2013), long-term inflation expectations had surpassed 5 percent. Panel $\mathrm{C}$ plots the standard deviation of respondents' inflation forecasts and is constructed as in Panels A and B. The degree of dispersion in long-term inflation expectations has edged up but remained been well below its peak in $2003 .^{9}$

\subsection{Financial Market-Based Inflation Expectations}

One shortcoming of using survey-based measures of long-term inflation expectations is that these measures are usually available only at relatively low frequencies; monthly, quarterly, or even semiannually. It is therefore difficult to truly gauge whether a central bank's inflation targeting framework is successful in shaping agents' expectations about future inflation.

Luckily, we can now derive much higher-frequency gauges of inflation expectations for Brazil, Chile, and Mexico from financial market data. Note that as recently as one decade ago this was still virtually impossible because bond markets were not yet well-developed in these countries. Since then, however, each country has made important strides forward, and depth and liquidity in these markets has risen substantially. As a result, we can now construct high-frequency measures of (farforward) inflation compensation using data on nominal and real bond prices, all typically available at a daily frequency. Market participants and policy makers alike heavily track these financial market-based measures for major industrialized countries to gauge the effect of macroeconomic news announcements and monetary policy decisions on market participants' perception of future inflation, for example using the event study analysis of the studies referenced in the introduction.

\footnotetext{
${ }^{9}$ Dispersion measures reflect the degree of disagreement among forecasters and are considered to be a reasonable proxy for inflation uncertainty. Beechey, Johanssen, and Levin (2011) compare the dispersion of survey-based measures of long-term inflation expectations in the euro area with that for the U.S. and find that the dispersion was higher in the U.S. Capistrán and Ramos-Francia (2010) find that the dispersion in short- and medium-term inflation expectations is lower in countries with inflation targeting than in countries without.
} 
Here we apply this same type of analysis specifically to our three EME countries.

One important caveat to using these measures, however, is that they do not necessarily offer a fully clean read on inflation expectations. As pointed out by Hördahl (2009), besides reflecting the level of expected inflation, inflation compensation also embeds inflation risk premia, liquidity premia, and technical factors. It is difficult, if not impossible, to distinguish these different factors without having to resort to strong identifying assumptions.

In this section, we first construct inflation compensation measures for Brazil, Chile, and Mexico. In particular, we use term structure estimation techniques to construct full term structures of inflation compensation at various horizons. To the best of our knowledge, we are the first to construct these measures in detail for Brazil and Mexico (and in a certain sense for Chile as well, although most of the work for Chile was done for us by RiskAmerica). We construct sufficientlylong historical time-series of market-based inflation compensation and then use these in our event study analysis in Section 4.

\subsubsection{Estimating Inflation Compensation Measures}

We estimate our financial-market-based inflation compensation measures as the spread between yields on nominal and inflation-indexed (real) sovereign bonds. The latter bonds have a principal value that is linked to inflation and therefore protect investors from inflation risk. While Brazil, Chile and Mexico all have had a reasonable number of inflation-linked bonds outstanding since at least the early 2000s, it is their nominal bond markets that have seen the most growth over the past decade. ${ }^{10}$ The fact that these countries have been able to issue long-term nominal debt is a sign of improved investor confidence in the central banks' ability to keep inflation low.

The now-outstanding spectrum of both nominal and real sovereign bonds allows us to construct nominal and real zero-coupon curves from these bonds, respectively. The zero curve estimation method we apply is that of Nelson and Siegel (1987) which has increasingly become the workhorse method for estimating zero curves from bond prices. ${ }^{11}$

A zero-coupon yield curve consists of the collection of interest rates earned on non-couponpaying bonds with increasing maturities. Because zero-coupon yields are not directly observable but are instead embedded in coupon-bearing bonds, we must resort to curve estimation techniques. Here we use the Nelson and Siegel (1987) model. This model postulates that the curve of continuouslycompounded zero-coupon yields at any given time $t$ can be well described by a smooth parametric

\footnotetext{
${ }^{10}$ In contrast, some developed economies, for example Germany and Japan, while having extremely liquid nominal bond markets, still have much less developed inflation-linked bond markets, with only a small number of bonds outstanding at any given time.

${ }^{11}$ For example, the Bank of International Settlements, (BIS, 2005), reports that nine out of the thirteen (predominantly European) central banks that report their zero-coupon curve estimates to the BIS use either the Nelson and Siegel (1987) model or an extension of it, the Svensson (1994) model, to construct zero-coupon yield curves.
} 
function which is determined by just four parameters;

$$
y_{t}(\tau)=\beta_{1, t}+\beta_{2, t}\left[\frac{1-\exp \left(-\frac{\tau}{\lambda_{t}}\right)}{\left(\frac{\tau}{\lambda_{t}}\right)}\right]+\beta_{3, t}\left[\frac{1-\exp \left(-\frac{\tau}{\lambda_{t}}\right)}{\left(\frac{\tau}{\lambda_{t}}\right)}-\exp \left(-\frac{\tau}{\lambda_{t}}\right)\right]
$$

where $y_{t}(\tau)$ is the model-implied $\tau$-period zero-coupon yield and $\left\{\beta_{1, t}, \beta_{2, t} \beta_{3, t}, \lambda_{t}\right\}$ is the parameter vector. These parameters can be interpreted as the level parameter, $\beta_{1, t}$; the slope parameter, $\beta_{2, t}$; and the curvature parameter, $\beta_{3, t}$, judging from the effect that a change in each of these respective parameters has on the shape of the curve, see for example Diebold and Li (2006). The fourth parameter, $\lambda_{t}$, is a shape parameter that influences the factor loadings associated with the slope and curvature parameters. We follow the approach of Gürkaynak, Sack, and Wright (2007b, 2010b) to estimate nominal and real zero-coupon curves from observed bond prices. In particular, we estimate the Nelson-Siegel parameters by minimizing the sum of squared approximate yield errors; bond price fitting errors weighted by the inverse of modified duration (MDur):

$$
\min _{\left\{\beta_{1, t}, \beta_{2, t} \beta_{3, t}, \lambda_{t}\right\}} \sum_{i=1}^{N_{t}}\left[\frac{P_{i, t}(\tau)-\widehat{P_{i, t}}(\tau)}{\operatorname{MDur}_{i, t}}\right]^{2}
$$

where $P_{i, t}(\tau)$ are the prices for the $N_{t}$ observable bonds on day $t$, either nominal or real bonds, and $\widehat{P_{i, t}}(\tau)$ are the bond price estimates implied by the Nelson-Siegel model.

When implementing the Nelson-Siegel model we must ensure that the optimization procedure converges to sensible and reliable zero curves. To accomplish this we impose several restrictions on the model parameters: (i) the level parameter $\beta_{1, t}$ is restricted to be positive and in the range $[0,25]$, (ii) the slope and curvature parameters - $\beta_{2, t}$ and $\beta_{3, t}$ respectively - are restricted to be in the range $[-100,100]$,(iii) the shape parameter, $\lambda_{t}$, is restricted to be contained in the range $[0.5,5]$. We only include bonds in the optimization that have a remaining maturity between three months and 15 years. An immediate problem arising from this particular maturity window is that our estimated yield curves could show odd behavior for maturities between zero and three months. Specifically, because by construction there are no data points on short-term rates, the short end of the curve could in theory go to either plus of minus infinity. To prevent this from happening, we impose that the Nelson-Siegel-implied instantaneous short rate, the sum of $\beta_{1, t}$ and $\beta_{, 2 t}$, has to be equal to the overnight rate, or, if the overnight rate shows erratic behaviour, the central banks' official target rate. ${ }^{12}$

Once we have estimates of the nominal and real zero-coupon curves for each day in the sample for our three countries, we take the difference between the two curves to construct an estimate of the inflation compensation curve. Furthermore, with the estimated Nelson-Siegel parameters, we

\footnotetext{
${ }^{12}$ This restriction on the model-implied instantaneous short rate turns out to work well as we were able to eliminate the occasional odd yield curve that resulted when not imposing the short rate restriction.
} 
can construct zero yields for any desired maturity. We can also easily compute nominal and real forward rates, and therefore forward inflation compensation estimates. We thus compute 1-year forward rates ending in 1, 2,.., 7 years in the future for Brazil and Mexico and 1-year forward rates ending in $1,2, \ldots, 10$ years for Chile. In this paper we only use the 1-year forward rate ending in 7 years for Brazil and Mexico and the 1-year forward rate ending in 10 years for Chile. ${ }^{13}$

\subsubsection{Bond Data}

\section{Brazil and Mexico}

We collected historical prices on nominal and inflation-linked bonds for Brazil and Mexico from several sources. Since our goal is to construct long-enough time series of far-forward inflation compensation, we combined data from different sources. For Brazil we obtained daily prices for all currently and previously outstanding bonds from Bloomberg and MorganMarkets. For Mexico we combined data from Bloomberg and Proveedor Integral de Precios (PiP). ${ }^{14}$

As is standard practice, we apply the usual filters to the available bond data; we do not include any bonds that have option-like features or floating coupon payments, and we do not include any bills out of concern that the behavior of bills can be quite different from that of bonds. From the remaining bonds, on any given day we only include those bonds that have a remaining maturity between 3 months and 15 years. ${ }^{15}$ The top two panels of Figure 5 show the number of bonds over time that were included in the estimations. ${ }^{16}$ For both Brazil and Mexico, the number of outstanding bonds has increased throughout the sample, in particular for nominal bonds. The total number of bonds continues to remain relatively small, however, likely introducing some degree of noise in our curve estimates. To shed some light on this issue, Figure 6 shows the average absolute bond price fitting errors for bonds with maturities between two and ten years. This metric is used in for example Gürkaynak, Sack, and Wright (2010b) to assess the fit of zero-coupon curve models. On average, we fit bond prices with an error of about 25 basis points. This is higher than the yield fitting errors that Gürkaynak, Sack, and Wright (2010b) report for likely more-liquid U.S. Treasury Inflation Protected Securities, but is certainly reasonable. ${ }^{17}$ Note that the fitting errors for both

\footnotetext{
${ }^{13}$ We leave analyzing the effects of macroeconomic news surprises on the full term structure of forward inflation compensation, such as is done in Beechey et al. (2011), for future research.

${ }^{14}$ For Morgan Markets, see https://mm.jpmorgan.com/. For PiP, see https://www.precios.com.mx/.

${ }^{15}$ Gürkaynak, Sack, and Wright (2007b) show that for estimating zero-coupon curves from U.S. Treasury bonds, one needs the Svensson (1994) model to accurately fit bond prices in the very longest end of the curve. However, the Svensson model requires estimating additional parameters compared with the Nelson and Siegel model. Therefore, due to the relatively small number of bond prices that we have available for any given day in our sample, we only consider maturities of up to fifteen years. In practice, only a few very long-maturity bonds have been issued in Brazil, Chile, and Mexico and imposing this restriction never removes more than one or two bonds.

${ }^{16}$ Because the Nelson-Siegel model is a four-parameter model, we can only construct zero-coupon curves on days where at least four bond prices are available.

${ }^{17}$ J.P. Morgan reports that liquidity in Mexican bond markets has improved over time, stating that the liquidity in 10-year Mexican bonds has "increased markedly", with bid-ask spreads having fallen and foreign holdings having risen from 18 percent in early 2006 to about 60 percent in August 2012, see J.P. Morgan (2006, 2012).
} 
Brazil and Mexico, in particular for inflation-index bonds in Mexico, spiked up at the height of the global financial crisis in late 2008, amidst large capital outflows from Latin American countries.

The bottom panels of Figure 5 show the longest-maturity bond used in the estimation. Panel C shows that Brazil did not issue its first long-maturity nominal bond until July 2006. We therefore start our data sample for Brazil in July 2006. Furthermore, even though Brazil has issued 10-year bonds at several times throughout our sample and has even issued a 15-year inflation-indexed bond in 2009, the longest maturity that is consistently outstanding throughout the sample is seven years. In order to prevent having to extrapolate our zero-coupon curves for longer maturities, we therefore use our curves only up to maturities of seven years. We do the same for Mexico. While the longest maturity that is consistently available for Mexico is eight years, we chose the same 7-year maximum maturity out of convenience. While studies that have examined far-forward inflation compensation for developed economies typically look at 1-year forward rates ending in 10 years, our 1-year forward rates ending in 7 years are still far enough in the future such that unforeseen shocks to prices and the real economy should not drive inflation away from the target if inflation expectations are well anchored.

\section{$\underline{\text { Chile }}$}

For Chile we use nominal and real zero-coupon curves that were graciously supplied to us by RiskAmerica. ${ }^{18}$ RiskAmerica estimates zero-coupon curves from prices on Chilean nominal and inflation-linked sovereign bonds, in a comparable fashion as we do here for Brazil and Mexico. RiskAmerica's zero-coupon estimates were similarly used by Gürkaynak et al. (2007a) to construct 1-year forward inflation compensation rates ending in 10 years when they examined whether inflation expectations were well-anchored in Chile between August 2002 and October 2005 (see the discussion in Section 4). Compared to Gürkaynak et al. (2007a), our sample for Chile is much longer; October 2, 2002 to April 30, 2012.

As noted by Gürkaynak et al. (2007a), although Chile had already been issuing inflation-linked bonds for several decades, it was not until 2002 that Chile began issuing long-term nominal bonds. However, since that time, the maturity of the longest-outstanding bond has consistently been above ten years. We therefore use 1-year forward inflation compensation rates ending in 10 years, similar to Gürkaynak et al. (2007a), as opposed to our forward inflation compensation measures for Brazil and Mexico, which end in seven years. Since Chilean forward rates are also based on fewer bonds than U.S. and U.K. forward rates, for example, they will tend to be more noisy. ${ }^{19}$

\footnotetext{
${ }^{18}$ See www.riskamerica.com.

${ }^{19}$ Gürkaynak et al. (2007a) show this point in their Figure 5B.
} 


\subsubsection{Far-Forward Inflation Compensation Estimates}

Figure 7 shows our market-based time-series estimates of far-forward nominal yields in Panel A, far-forward real yields in Panel B, and far-forward inflation compensation in Panel $\mathrm{C}$. The farforward inflation compensation measures plotted in Panel $\mathrm{C}$ are the spread between the forward rates in the top two panels, and are the same as those shown in the bottom panels of Figures 1 - 3. We can make a number of general observations here, which are similar to those made by Gürkaynak et al. (2007a) in their analysis of Chilean inflation compensation. First, the fact that all three governments were able to issue long-term nominal debt by the mid-2000s is a sign that inflation expectations have become better anchored. Previously, investors had demanded higher yields for long-term debt than what governments were willing to pay. Second, far-forward inflation compensation varies considerably, particularly for Brazil, where it spikes in late 2008. Third, farforward inflation compensation for Brazil and Mexico have nearly always been above the inflation targets of $4 \frac{1}{2}$ and 3 percent, but for Chile has been both below and above the 3 percent target.

Comparing Figure 1 and Figure 7 shows that for Brazil far-forward inflation compensation rises after 2007, as does actual inflation and the Consensus survey-based measure of long-term inflation expectations. Far-forward inflation compensation goes well above the survey measure in 2008, most likely reflecting market disfunction. But even over the last two years of our sample, it is often about 1 to $1 \frac{1}{2}$ percentage points above the average from Consensus' survey, although by the end of the sample period in April 2013, it is not much higher than the average and median expectations from the CBB's weekly survey (Figure 4).

For Mexico, far-forward inflation compensation declines considerably between 2003 and 2005, and is very close to $3 \frac{1}{2}$ percent for a period in 2007 and 2008. Inflation compensation then moves up in 2009 and has exceeded the survey-based measures of inflation expectations since, but by a lesser degree than in Brazil.

One interpretation of the spread between inflation compensation and the survey-based inflation expectations is that investors have not been confident that either the CBB or BOM will be able to achieve its inflation goal and have demanded extra compensation for the risk of higher inflation, and more so in Brazil than in Mexico. By taking the difference between our far-forward inflation compensation measures in Figure 7 and the long-term survey forecasts in the middle panels of Figure 1 - 3 we can calculate a rough estimate of the inflation risk premium for each country. Doing so implies an inflation risk premium of about $1 \frac{1}{2}$ percent for Brazil, $\frac{1}{2}$ percent for Mexico and 0 percent for Chile (compared with an estimate of about 0 percent for the United States for example). Although above zero, these figures are remarkably low given each country's historical inflation record and indicate the progress that the $\mathrm{CBB}$ and BOM have made towards convincing investors of their ability to contain inflation. 


\section{Sensitivity of Yields and Inflation Compensation to News}

Previous studies that use financial-market-based estimates of far-forward inflation compensation to examine whether inflation expectations are well anchored, have almost exclusively focused on developed economies. For example, Gürkaynak et al. (2005), Gürkaynak et al. (2007a), Gürkaynak et al. (2010a), and Beechey et al. (2011) examined the U.S., U.K., Canada, and Sweden. We fill in this gap in the literature for Brazil, Chile and Mexico using the inflation compensation measures that we constructed in Section 3.2. ${ }^{20}$

We build upon the regression analyses used in the studies referenced above by regressing daily changes in forward nominal and real yields and, in particular, far-forward inflation compensation on the surprise component of news announcements on monetary policy, consumer prices, and the real economy. The premise here is that if inflation expectations are well anchored over the long term, far-forward inflation compensation should not react significantly to news surprises. If they do react significantly, then this is a indication that inflation expectations remain unanchored.

\subsection{Regression Approach}

We estimate the parameters of the following linear regression specification:

$$
\Delta y_{t, n}=\alpha_{n}+\beta_{n} X_{t}+\gamma_{n} Z_{t}+\epsilon_{t, n} \quad \epsilon_{t, n} \sim \operatorname{IID}\left(0, \sigma_{n}^{2}\right)
$$

where $\Delta y_{t, n}$ is the daily change in either (forward) nominal or real rates, or far-forward inflation compensation ending in $n$ years ${ }^{21}$ and $X_{t}$ is the vector of news surprises. In our baseline regressions, $Z_{t}$ includes a dummy that equals one on the first business day of each calendar year, and zero elsewhere.

We are interested in which, if any, of the surprises included in the regression have a significant impact on inflation compensation, in which direction surprises move inflation compensation, and the size of these moves overall. Furthermore, to assess whether inflation expectations are overall well anchored or not, we perform a standard Wald test, testing the joint null hypothesis that all news surprise coefficients in the regression are equal to zero (i.e. we test the hypothesis that $\beta_{1}=\beta_{2}=\ldots=\beta_{K}=0$ with $K$ the number of news surprises.).

We not only examine whether domestic news surprises move inflation compensation for Brazil, Chile, and Mexico, but also whether news surprises from abroad have a significant impact, specifically news surprises from the U.S. and China. We do so by rerunning the regressions in (3), but

\footnotetext{
${ }^{20}$ Gürkaynak et al. (2007a) also study inflation compensation in Chile and find that it does not react significantly to Chilean and U.S. news surprises. However, due to data limitations they only analyzed the relatively short sample from August 2002 to October 2005. Furthermore, their set of news surprises was small and, as the authors note, the survey measures used were likely to be somewhat stale. Here we use a much longer time series of inflation compensation, as well as a larger set of economic news surprises, as discussed in Section 4.2.

${ }^{21}$ Recall that we use $n=7$ for Brazil and Mexico, while we use $n=10$ for Chile.
} 
now with an extended $X_{t}$ that includes either U.S. or Chinese news surprises (we examine these in separate regressions). All three countries that we analyze are open economies, with the U.S. and China being major trading partners. News surprises from the U.S and China could therefore influence interest rates in Brazil, Chile, and Mexico, but should not influence investors' views on long-term inflation expectations in these countries if inflation expectations are well anchored.

In a sensitivity analysis to our baseline results in Appendix A, we follow Galati et al. (2011) by including a vector of control variables in $Z_{t}$ to account for the fact that inflation compensation not only reflects inflation expectations, but also inflation risk premia, liquidity, and technical factors. By including variables that are aimed at controlling for the latter two factors, we attempt to restrain the influence of variation in liquidity and other technical factors that is not directly related to inflation expectations. ${ }^{22}$ Galati et al. (2011) also examined the effect that the financial crisis has had on the anchoring properties of inflation expectations in the U.S., U.K., and the euro area. They found that inflation expectations may have become less well anchored as a result of the crisis, which erupted in mid-2007. Given their results, we therefore also examine subsamples from before and after mid-2007 to assess the stability of our full-sample results. Finally, in Appendix B we present some regression results using 5-year rolling windows.

\subsection{News Surprise Data and Controls}

Similar to the previous literature, we include surprises on a range of real economy, price and monetary policy-related announcements; (1) the central bank policy rate, (2) headline consumer prices (CPI), (3) industrial production (IP), (4) purchasing managers index (PMI), (5) retail sales, (6) trade balance (defined as exports minus imports), (7) real GDP, and (8) the unemployment rate. We obtained all data releases and survey expectations from Bloomberg ${ }^{23}$ and these eight announcements are the ones for which we have data available with a sufficiently long history. ${ }^{24}$ For U.S. surprises, we follow others, in particular Gürkaynak et al. (2007a), by also including: (9)

\footnotetext{
${ }^{22}$ As noted by Galati et al. (2011), because inflation compensation is defined as the difference between nominal and real (forward) rates, we already filter out most of the impact of liquidity and technical factors, provided that these affect nominal and real bond prices in a similar way.

${ }^{23}$ To construct survey expectations for economic data releases, Bloomberg initially asks respondents to input their forecasts two weeks prior to the actual release. Respondents can then submit their forecast or change their previously submitted forecast up until roughly one hour before the release time of the announcement.

${ }^{24}$ The PMIs for Brazil and Chile are not available. Instead of Markit Group's PMI for Mexico, we include the business climate index produced by the Mexican Institute of Finance Executives (IMEF). This series starts in mid2009. For Chile, we use total IP until the end of 2011 and manufacturing IP after that. We shifted forward by one business day the CBB's monetary policy rate decisions as these are released after the close of business and do not fully affect market interest rates until the following day. Finally, the BOM did not formally adopt a target for Mexico's overnight bank funding rate (tasa de fondeo) until January 2008. However, the BOM is widely viewed as already having implicitly targeted the funding rate prior to 2008 as well, which is the reason pre-2008 survey values are available in Bloomberg. Between September 2005 and December 2007, our monetary policy surprise is therefore the difference between the tasa de fondeo and the Bloomberg survey forecast whereas after December 2007, the monetary policy surprise is the difference between BOMs target for the tasa de fondeo and the Bloomberg survey forecast.
} 
consumer confidence, (10) initial jobless claims, (11) new home sales, (12) and the nonfarm payrolls report.

To measure the size of the surprise involving each data release, we compute the difference between the actual release and the median Bloomberg survey forecast. By including only the surprise component in the regressions, we take out the expected component of the information contained in any news release and which should have already been incorporated in bond yields. We normalize all surprises by their standard deviation, with the exception of policy rate surprises which are recorded in basis points.

As control variables in our sensitivity analysis, we include daily changes in (1) the VIX, (2) the 12-month WTI futures contract, and (3) the 3-month food futures contract, all of which we obtained from Bloomberg. The VIX serves as a control of overall market volatility, and can also be seen as a control for general investor risk appetite. We include oil and food futures contracts to control for the pass-through of commodity price developments to domestic prices. For example, pass-through from global food shocks tends to be higher in emerging markets compared with developed economies because food is typically a larger component of CPI in emerging markets.

\subsection{Outlier Analysis}

Before we present our main empirical results, we first address the potential impact of outliers in our announcement data. We need to make sure that our results for overall and individualvariable (in)significance will not be driven by just a few influential observations. As the number of announcements per variable will be small given their monthly or even quarterly release calendar, and because only true surprises in the announcements yield non-zero observations, outliers could play a significant role. Therefore, in a preliminary step, we first run simple linear regressions for each country, regressing our left-hand variables in (3) on each individual surprise variable and examine whether any observations qualify as regression outliers. We evaluate individual $(x, y)$ observation pairs based on their leverage through their hat-values, studentized residuals, and Cook's distance. ${ }^{25}$ We characterize an observation as an outlier if its Cook's distance is greater than the cut-off ruleof-thumb value $\frac{4}{N-2}$ (with $N$ the number of observations in the regression), its hat value is larger than the average hat value of $\frac{4}{N}$, and its studentized residual is outside its $95 \%$ confidence interval of \pm 2 .

We present the results of our outlier analysis graphically in Figures 8 - 10. In total, we identified four observations per country as outliers in the regressions for far-forward inflation compensation. For Brazil we found outliers in the policy rate (the release of July 24, 2008), CPI (December 7, 2012), IP (March 6, 2009), and GDP (March 10, 2009). For Chile these were in the policy rate (December 11, 2003), CPI (January 6, 2009), trade balance (September 7, 2007), and the unemployment

\footnotetext{
${ }^{25}$ See Cook and Weisberg (1982) for details and a general discussion on outlier detection.
} 
rate (November 27, 2003). Finally, for Mexico, these were in CPI (May 7, 2010), PMI (August 3, 2011), retail sales (May 26, 2003), and GDP (August 16, 2005). All these observations are labeled by their date in Figures 8 - 10 in the left-hand-side panels (which show hat-values on the horizontal axes, studentized residuals on the vertical axes, and relative Cook's distances as the radius of the circles) as well as in the right-hand-side panels (which show the simple regression lines for far-forward inflation compensation with and without including the outliers in the regression, the solid black and dashed blue lines, respectively). Judging from the right panels, regression coefficients are generally little affected by outliers. However, there are some notable exceptions. In particular, removing Brazil's IP outlier substantially increases its regression coefficient from 1.30 (insignificant) to 4.96 (significant at 5\%), while removing the GDP outlier substantially reduces its regression coefficient from 7.87 (significant at 10\%) to 3.76 (insignificant). ${ }^{26}$ With the outliers for Brazil being an example of the extent to which influential observations could indeed affect our regressions results, we removed all outliers and only present outlier-corrected results in the remainder of this section.

\subsection{Full-Sample Results}

\subsubsection{Baseline Regressions}

Tables 1 through 3 present the main empirical results of our analysis, showing results for the regressions in (3) using our full available history of inflation compensation and news surprises. We included only days that had at least one data announcement and we excluded the volatile fourth quarter of 2008 to not contaminate the regression results with such a volatile period. ${ }^{27}$ Our baseline regressions include only domestic new surprises, plus a constant and the dummy that equals one only on the first business day of the year.

The first two columns in each table show the number of included observations per individual variable and the standard deviation of each variable's surprises. By combining standard deviations with regression coefficients we can assess the economic impact of surprises. The remaining columns show regression results using as dependent variables the 1-day changes in: the 1-year nominal rate (column 3), the 1-year forward nominal rate ending in 7 or 10 years depending on the country (column 4) and the breakdown of this into the 1-year forward real rate (column 5) and our main variable of interest, the 1-year far-forward inflation compensation rate (column 6). All reported coefficients should be interpreted as the response (in basis points) to a one-standard deviation

\footnotetext{
${ }^{26}$ In the case of the outlier in Brazil's GDP, one could make a case for keeping it in the regression given that inflation compensation reacted as one would expect in response to the negative GDP surprise; by moving down. However, given the outsized move in inflation compensation and the influence that this single observation has on the slope of the regression line, removing this observation as an outlier seems reasonable.

${ }^{27}$ In our sensitivity analysis in Appendix A, among other alternative specifications, we also address the approach of including all days, which entails including a substantial number of days with zero values for surprises, as well as including the fourth quarter of 2008.
} 
surprise in the data release of the corresponding macrovariable (with the exception of the policy rate coefficient which is the response in basis points to a one basis point rate surprise). We use regular OLS standard errors to assess the significance of individual surprise variables (using HAC-style standard errors resulted in very similar results). We highlight surprises that enter the regression significantly; with $* * *$ indicating significance at the $1 \%$ level, ${ }^{* *}$ at the $5 \%$ level and * at the $10 \%$ level. Student $t$-statistics are reported in parentheses underneath each regression coefficient. The results for the joint significance test of news surprises are reported in the bottom two rows of each table.

The first observation to make from Tables 1 through 3 is that short-term interest rates, as represented by the 1-year nominal rate in the third column, respond significantly to sometimes an array of different surprises, but in particular to surprises in the policy rate, consumer prices, industrial production and GDP growth. This is not surprising, given how strongly correlated shortterm interest rates are with the state of the economy. The signs and magnitudes of significant coefficients seem reasonable. For example, if the central bank unexpectedly raises its policy rate by 100 basis points, then short-term rates tend to increase by 31 basis points in Brazil, 10 basis points in Chile, and 60 basis points in Mexico. The reaction of Brazilian short rates to policy rates surprises is very close in magnitude to what Gürkaynak et al. (2007a) found for the reaction of U.S. short rates to Federal Reserve policy rate surprises. Similarly, an unexpected 1 percentage point increase in IP raises short-term rates by a little over $3 \frac{1}{2}$ basis points in Brazil and around 1 basis point in Chile and Mexico, while a 1 percent drop in the unemployment rate (a four-standard-deviation event) reduces short-term rates in Brazil by about 8 basis points.

The $R^{2}$ s confirm that news surprises explain changes in 1-year rates quite well, which is corroborated by the results of the Wald-test, which for each country strongly rejects the null hypothesis that news surprises do not significantly affect short-term interest rates.

In contrast, the final column in each table shows that the $R^{2} \mathrm{~s}$ in the regressions for far-forward inflation compensation are low. Furthermore, surprises do not significantly affect far-forward inflation compensation for Brazil and Mexico according to the joint Wald test, as its null hypothesis cannot be rejected at the standard $5 \%$ level. However, we find that inflation compensation does react significantly to some individual surprises, in particular to IP for Brazil (at the $5 \%$ level) and Mexico (at the 10\% level), with a two standard-deviation surprise raising inflation compensation by about ten and three basis points in these countries. IP is the only variable (for Mexico also CPI) in the inflation-compensation regressions for Brazil and Mexico that comes in significant, indicating that long-term inflation compensation in these countries does not systematically react to macro news surprises and that inflation expectations therefore appear to be well anchored.

For Chile on the other hand, we find that the null of the Wald test is rejected for the full data sample, which is driven by the strong significance of CPI surprises in the regression. However, the 
$R^{2}$ remains low and it takes a four standard-deviation, 1 percent, unexpected increase in Chilean inflation to increase inflation compensation by 16 basis points. Furthermore, the coefficients of all other surprises are either not significant, or weakly significant at best (GDP and trade).

We checked the robustness of our baseline results by examining a serious of alternative specifications. The results of this sensitivity analysis are discussed in Appendix A and show that our results are indeed robust.

\subsubsection{Including Foreign Surprises}

We now examine full-sample results when we also include in the baseline regressions U.S. news surprises, in Table 4, and Chinese news surprises, in Table 5. Here we only report results for the 1year nominal rate and 1-year far-forward inflation compensation. The top part of each table shows the coefficients on domestic surprises, while the bottom part shows the regression coefficients and their significance on U.S. and Chinese news surprises, respectively. In the regressions for the daily changes in 1-year nominal rates, domestic surprises that were significant before remain significant with the similar sign and magnitude of coefficients. The bottom half of the table shows that with the exception of U.S. trade for Chile, none of the U.S. surprises come in significantly. For Mexico, at least, this result seems surprising because important macroeconomic data, in particular IP and GDP, are released with a considerable delay. As shown in Table 6, several U.S. macro figures are released before the first domestic news release in Mexico (similarly for Brazil and Chile). Therefore, because of the substantial lag with which domestic macro news is released, and because of the strong economic linkages between Mexico and the U.S., one would expect that at least some of the U.S. news surprises would have an impact on short-term rates. However, we do not find evidence of this.

As judged by the third column in the table for each country, far-forward inflation compensation does appear to react significantly to a few U.S. news releases. On the one hand, this could indicate that even if the local central banks are able to make long-term inflation expectations resilient to domestic news surprises, they have trouble overcoming the effects of U.S. news surprises on domestic inflation expectations. On the other hand, however, some of these results could also just represent statistical noise. For example, the coefficient on U.S. CPI surprises is negative and significant in the regression for both Chile and Mexico, implying that positive inflation surprises in the U.S. would lower inflation compensation in these countries, which is not an obvious relationship. One result that does seem worth examining further is how stable over time the positive and significant coefficient of U.S. nonfarm payrolls is for Chile and Mexico (although not significant, its coefficient is also positive for Brazil). We do so in Appendix B using rolling regressions.

The results for Chinese news surprises in Table 5 show that only Brazilian inflation compensation is affected by some data releases in China. This seems in line with the fact that there is very little 
trade between Mexico and China, while the trade share with China is more important for Brazil. ${ }^{28}$ According to the regression results, a three-standard deviation surprise in Chinese IP (equivalent to a surprise increase of four percentage points) leads to a 15 basis point increase in Brazilian inflation compensation, which does not seem unreasonable. On the other hand, however, the coefficient on Chinese GDP surprises in the regression for Brazil has the opposite sign, again alluding to statistical noise. For Chile, whose trade share with China is comparable, we do not find evidence of any impact of Chinese news surprises.

\subsection{Subsample Results}

\subsection{1 (Pre-)Crisis Period}

To address the potentially destabilizing effects of the financial crisis, we re-estimate our baseline regressions by splitting up the sample in a pre-crisis sample (using data up until July 2007) and a crisis period (using data from July 2007 onwards). Results are shown in Tables 7 - 9 with pre-crisis results in the first three columns and results since July 2007 in the last three columns. The pre-crisis results for Brazil in Table 7 show that the joint test rejects, driven by (weakly) significant coefficients on the policy rate and the unemployment rate, suggesting that prior to the financial crisis, inflation expectations in Brazil were not well anchored. However, the pre-crisis sample for Brazil only consists of just one calendar year of data, with just over sixty observations on surprises overall, and even fewer per individual variable. For example, the significant, but unexpectedly positive, coefficient for policy rate surprises in the third column is due to a single negative surprise (an unexpected 25 basis point cut in the benchmark Selic rate on August 30, 2006) that lowered inflation compensation. Since the onset of the crisis, inflation expectations have been well anchored, as judged by the Wald statistic. IP surprises continue to have a (weakly) significant impact, however, on far-forward inflation compensation.

Table 8 shows the high Wald statistic for Chile in both the pre-crisis and crisis period. Our pre-crisis results for Chile are in contrast with the results of Gürkaynak et al. (2007a) who found that inflation expectations were well-anchored between August 2002 and October 2005. However, as noted earlier, our sample is longer and incorporates more news surprises. Since the advent of the crisis, Chilean inflation compensation continues to significantly react to CPI surprises. However, both the $R^{2}$ and the Wald-statistic have decline somewhat. Table 9 shows that the results for Mexico for the pre-crisis and crisis periods are very similar. During the crisis period, the coefficient of policy rate surprises is negative and significant, as unexpected rate hikes early in the crisis

\footnotetext{
${ }^{28}$ In recent years, over 75 percent of Mexico's exports have gone to the United States. Since the mid-2000s, the share of Brazilian and Chilean exports to China has grown from about 5 and 15 percent in the mid-2000s to 15 and 20 percent more recently. The United States remains important as an export destination for these two countries but less so since the mid-2000s. Over the past 3 years, about 10 percent of Brazil's and Chile's exports went to the United States.
} 
lowered inflation compensation, while the BOM's unexpected rate cut on March 8, 2013-its first rate adjustment since 2009 - pushed up inflation compensation.

Overall, we find no clear evidence of any changes in the anchoring of inflation expectations since the onset of the financial crisis in Brazil, Chile, and Mexico. A more sophisticated subsample analysis to assess the impact of the financial crisis could perhaps shed more light on the anchoring of inflation expectations before and since the crisis, for example an approach of formally testing for breaks as used in Galati et al. (2011). However, we do not address this here and leave this interesting approach for further research. In Appendix B, we do analyze the results of a somewhat more structured approach to subsample analysis by showing rolling-window regressions results, using 5-year moving windows. These generally confirm the subsample results presented here.

\section{Conclusion}

In this paper, we explored whether long-term inflation expectations have become better anchored in Brazil, Chile, and Mexico, all having adopted inflation-targeting frameworks as their monetary policy strategy over a decade ago to put an end to high inflation. We examined how close inflation expectations have been to the announced inflation targets through an informal and formal analysis, using survey-based as well financial-market-based measures of inflation expectations.

We find that survey-based measures of medium- and long-term inflation expectations in all three countries have been close to or at the inflation target, despite differences among the three with respect to the ways that the central banks communicate their commitment to low inflation. Measures of far-forward inflation compensation derived from Chilean sovereign bond prices suggest that for the most part investors have been confident that the Central Bank of Chile will bring inflation back to the target. For Brazil and Mexico, far-forward inflation compensation has tended

to exceed the inflation target by 1 to $1 \frac{1}{2}$ percentage points in most recent years, suggesting that investors have demanded extra compensation to allow for the risk that the inflation target will not be met in either country. For Brazil, the inflation risk premium might reflect some uncertainty about the long-term inflation target, which would be consistent with the upward drift in the surveybased measure of inflation expectations. These inflation risk premia are remarkably small, however, considering both Brazil's and Mexico's more recent inflationary record.

Our regression analysis shows that inflation compensation has been sensitive to the surprises of at least one domestic macro variable in each country, and to some U.S. and Chinese new surprises. However, the impact of these surprises is small and it does not appear that investors systematically alter their expectations for inflation as a result of surprises in monetary policy, consumer prices, or real activity variables. Overall, our results show that Brazil, Chile, and Mexico have done a remarkable job in convincing investors that their inflation targets are credible and that inflation can be contained. 


\section{References}

Andersson, M., L. J. Overby, and S. Sebestyén (2009), Which News Moves the Euro Area Bond Market?, German Economic Review, 10, 1-31.

Ball, L. (2011), The Performance of Alternative Monetary Regimes, in K. J. Arrow and M. D. Intriligator (eds.), Handbook of Monetary Economics, North-Holland, 1303-1343.

Ball, L. and N. Sheridan (2005), Does Inflation Targeting Matter?, in B. S. Bernanke and M. Woodford (eds.), The Inflation Targeting Debate, NBER Studies in Business Cycles, Vol. 32, University of Chicago Press, Chicago, IL.

Batini, N. and D. Laxton (2006), Under What Conditions Can Inflation Targeting Be Adopted? The Experience of Emerging Markets, Central Bank of Chile Working Paper No. 406.

Beechey, M. J., B. K. Johanssen, and A. T. Levin (2011), Are Long-Run Inflation Expectations Achored More Firmly in the Euro Area than in the United States?, American Economic Journal: Macroeconomics, 3, 104-129.

BIS (2005), Zero-Coupon Yield Curves: Technical Documentation, Bank for International Settlements, Basel.

Brito, R. D. and B. Bystedt (2010), Inflation Targeting in Emerging Economies: Panel Evidence, Journal of Development Economics, 91, 198-210.

Capistrán, C. and M. Ramos-Francia (2010), Does Inflation Targeting Affect the Dispersion of Inflation Expectations?, Journal of Money, Credit and Banking, 42, 113-134.

Carstens, A. and A. Werner (1999), Mexico's Monetary Policy Framework under a Floating Exchange Rate Regime, Bank of Mexico Research.

Cook, R. D. and S. Weisberg (1982), Residuals and Influence in Regression, Chapman \& Hall, London.

Diebold, F. X. and C. Li (2006), Forecasting the Term Structure of Government Bond Yields, Journal of Econometrics, 130, 337-364.

Fraga, A. (2000), Brazil's Recent Experience, Finance \& Development, 37.

Fraga, A. (2009), Dez Anos de Metas para a Inflação, Central Bank of Brazil, 10 Years of Inflation Targets in Brazil 1999-2009 [in Portuguese].

Fraga, A., I. Goldfajn, and A. Minella (2004), Inflation Targeting in Emerging Market Economies, NBER Macroeconomics Annual 2003, Volume 18; eds M. Gertler and K. Rogoff; The MIT Press.

Galati, G., S. Poelhekke, and C. Zhou (2011), Does the Crisis Affect Inflation Expectations?, International Journal of Central Banking, 7, 167-207.

Goldfajn, I. (2007), Eclyse e a meta de inflação, O Estado de São Paulo, July 3.

Gomes, W. (2004), Meirelles: transição para meta de 4inflação ao ano será suave, O Globo Online, July 5.

Gonçalves, C. E. S. and J. M. Salles (2002), Term Structure of Interest Rates with Regime Shifts, Journal of Finance, 57, 1997-2043.

Grinbaum, R. (2012), Para BC, não dá para baixar meta de inflação, O Estado de São Paulo, October 24. 
Gürkaynak, R. S., A. T. Levin, A. N. Marder, and E. T. Swanson (2007a), Inflation Targeting and the Anchoring of Inflation Expectations in the Western Hemisphere, Monetary Policy under Inflation Targeting; eds F. Mishkin and K. Schmidt-Hebbel; Central Bank of Chile; Santiago, Chile, 415-465.

Gürkaynak, R. S., A. T. Levin, and E. T. Swanson (2010a), Does Inflation Targeting Anchor LongRun Inflation Expectations? Evidence from the U.S., U.K., and Sweden, Journal of the European Economic Association, 8, 1208-1242.

Gürkaynak, R. S., B. Sack, and E. T. Swanson (2005), The Sensitivity of Long-Term Interest Rates to Economic News: Evidence and Implications for Macroeconomic Models, American Economic Review, 95, 425-436.

Gürkaynak, R. S., B. Sack, and J. H. Wright (2007b), The U.S. Treasury Yield Curve: 1961 to the Present, Journal of Monetary Economics, 54, 2291-2304.

Gürkaynak, R. S., B. Sack, and J. H. Wright (2010b), The TIPS Yield Curve and Inflation Compensation, American Economic Journal: Macroeconomics, 2, 70-92.

Hammond, G. (2012), State of the Art of Inflation Targeting, Centre for Central Banking Studies, Handbook - No. 29, Bank of England.

Hördahl, P. (2009), Disentangling the Drivers of Recent Shifts in Break-Even Inflation Rates, Bank of International Settlements Quarterly Review, March, 10-11.

J.P. Morgan (2006), Local Markets Guide, March 2006.

J.P. Morgan (2012), Local Markets Guide, September 2012.

Levin, A. T., F. M. Natalucci, and J. M. Piger (2004), The Macroeconomic Effects of Inflation Targeting, Federal Reserve Bank of St. Louis Review, 86, 51-80.

Mishkin, F. S. and M. Savastano (2001), Monetary Policy Strategies for Latin America, Journal of Development Economics, 66, 415-444.

Nelson, C. R. and A. F. Siegel (1987), Parsimonious Modeling Of Yield Curves, Journal of Business, 60, 473-489.

Obstfeld, M. and K. Rogoff (1995), The Mirage of Fixed Exchange Rates, Journal of Economic Perspectives, 9, 73-96.

Ramos-Francia, M. and A. Torres-García (2005), Reducing Inflation Through Inflation Targeting: The Mexican Experience, Bank of Mexico Working paper, No. 2005-01.

Svensson, L. E. O. (1994), Estimating and Interpreting Forward Interest Rates: Sweden 1992-1994, NBER Working Paper Series, No. 4871.

Valdés, R. (2007), Inflation Targeting in Chile: Experience and Selected Issues, Central Bank of Chile, Economic policy paper, No. 22. 
Table 1: BRAZIL: Baseline Model (Full Sample: Jul-2006 - Apr-2013)

\begin{tabular}{|c|c|c|c|c|c|c|}
\hline variable & $\begin{array}{l}\text { number } \\
\text { of obs. }\end{array}$ & $\begin{array}{l}\text { stdev. } \\
\text { surprise }\end{array}$ & $\begin{array}{c}1-y r \\
\text { nominal rate }\end{array}$ & $\begin{array}{l}\text { 1-yr forward } \\
\text { nominal rate } \\
\text { ending } 7 \text { yrs } \\
\end{array}$ & $\begin{array}{l}\text { 1-yr forward } \\
\text { real rate } \\
\text { ending } 7 \text { yrs } \\
\end{array}$ & $\begin{array}{l}\text { 1-yr forward } \\
\text { infl. comp. } \\
\text { ending } 7 \text { yrs }\end{array}$ \\
\hline \multicolumn{7}{|l|}{ Macro News Surprises } \\
\hline POLICY RATE & 53 & - & $\begin{array}{l}0.31^{* * *} \\
(4.91)\end{array}$ & $\begin{array}{l}-0.18 \\
(-1.18)\end{array}$ & $\begin{array}{l}-0.31^{* * *} \\
(-3.83)\end{array}$ & $\begin{array}{c}0.13 \\
(0.84)\end{array}$ \\
\hline CPI & 78 & 0.06 & $\begin{array}{l}2.48^{* * *} \\
(3.21)\end{array}$ & $\begin{array}{l}1.75 \\
(0.94)\end{array}$ & $\begin{array}{c}-0.41 \\
(-0.40)\end{array}$ & $\begin{array}{c}2.12 \\
(1.08)\end{array}$ \\
\hline IP & 78 & 1.09 & $\begin{array}{l}3.49^{* * *} \\
(4.82)\end{array}$ & $\begin{array}{c}1.21 \\
(0.70)\end{array}$ & $\begin{array}{l}-0.12 \\
(-0.13)\end{array}$ & $\begin{array}{l}4.84^{* *} \\
(2.13)\end{array}$ \\
\hline PMI & - & - & - & - & - & - \\
\hline RETAIL SALES & 79 & 1.30 & $\begin{array}{l}1.41^{*} \\
(1.89)\end{array}$ & $\begin{array}{c}1.90 \\
(1.09)\end{array}$ & $\begin{array}{l}-0.32 \\
(-0.34)\end{array}$ & $\begin{array}{c}2.17 \\
(1.20)\end{array}$ \\
\hline TRADE BALANCE & 78 & 602 & $\begin{array}{l}-1.01 \\
(-1.18)\end{array}$ & $\begin{array}{l}1.23 \\
(0.60)\end{array}$ & $\begin{array}{l}-1.80 \\
(-1.63)\end{array}$ & $\begin{array}{c}3.25 \\
(1.53)\end{array}$ \\
\hline GDP & 26 & 0.44 & $\begin{array}{c}4.99^{* *} \\
(2.41)\end{array}$ & $\begin{array}{l}7.84^{* *} \\
(2.46)\end{array}$ & $\begin{array}{l}-1.47 \\
(-0.74)\end{array}$ & $\begin{array}{c}3.19 \\
(0.79)\end{array}$ \\
\hline UNEMPL. RATE & 79 & 0.27 & $\begin{array}{l}-1.94^{* * *} \\
(-2.68)\end{array}$ & $\begin{array}{l}-0.55 \\
(-0.32)\end{array}$ & $\begin{array}{c}0.63 \\
(0.67)\end{array}$ & $\begin{array}{c}-1.17 \\
(-0.65)\end{array}$ \\
\hline $\begin{array}{l}\text { Total number of obs. } \\
R^{2} \\
\text { adj. } R^{2}\end{array}$ & & & $\begin{array}{l}425 \\
15 \% \\
14 \%\end{array}$ & $\begin{array}{l}427 \\
3 \% \\
1 \%\end{array}$ & $\begin{array}{l}426 \\
4 \% \\
2 \%\end{array}$ & $\begin{array}{l}424 \\
3 \% \\
1 \%\end{array}$ \\
\hline $\begin{array}{l}\text { Wald-statistic } \\
(p \text {-value })\end{array}$ & & & $\begin{array}{l}75.54 \\
(0.00)\end{array}$ & $\begin{array}{l}10.55 \\
(0.16)\end{array}$ & $\begin{array}{l}18.08 \\
(0.01)\end{array}$ & $\begin{array}{l}11.17 \\
(0.13)\end{array}$ \\
\hline
\end{tabular}

Notes: The table shows results in columns three to six of regressing Brazilian short-term and 1-year far-forward rates on several domestic macro news surprises for the full sample period July 2006 - April 2013, including only those days on which at least one Brazilian macroeconomic figure is released. The surprises in the policy rate are recorded in basis points, while all other macroeconomic surprises are normalized by their standard deviation. The first column shows the number of included observations per individual news surprise. The second column in the table shows the magnitude of a one-standard deviation surprise, expressed in the unit of each surprise; percentage terms for each variable, except for PMI which is in points, and trade balance which is in millions of dollars. Besides the surprise variables shown, also included in the regressions are a constant and a dummy that takes on the value of one on the first business day of the year and zero on all other days. Student- $t$ statistics are presented between parentheses, while *** indicates significance at the $1 \%$ level, ${ }^{* *}$ at the $5 \%$ level and ${ }^{*}$ at the $10 \%$ level. The Wald statistic and accompanying $p$-value are for testing the null hypothesis that all coefficients (with the exception of the constant and the yearly dummy) are equal to zero. 
Table 2: CHILE: Baseline Model (Full Sample: Oct-2002 - Apr-2013)

\begin{tabular}{|c|c|c|c|c|c|c|}
\hline variable & $\begin{array}{l}\text { number } \\
\text { of obs. }\end{array}$ & $\begin{array}{l}\text { stdev. } \\
\text { surprise }\end{array}$ & $\begin{array}{c}1-y r \\
\text { nominal rate }\end{array}$ & $\begin{array}{l}\text { 1-yr forward } \\
\text { nominal rate } \\
\text { ending } 7 \text { yrs }\end{array}$ & $\begin{array}{l}\text { 1-yr forward } \\
\text { real rate } \\
\text { ending } 7 \text { yrs }\end{array}$ & $\begin{array}{l}\text { 1-yr forward } \\
\text { infl. comp. } \\
\text { ending } 7 \text { yrs }\end{array}$ \\
\hline \multicolumn{7}{|l|}{ Macro News Surprises } \\
\hline POLICY RATE & 124 & - & $\begin{array}{l}0.10^{* * *} \\
(3.14)\end{array}$ & $\begin{array}{l}-0.03 \\
(-0.74)\end{array}$ & $\begin{array}{c}0.00 \\
(0.01)\end{array}$ & $\begin{array}{l}-0.04 \\
(-0.71)\end{array}$ \\
\hline CPI & 87 & 0.26 & $\begin{array}{l}4.45^{* * *} \\
(6.58)\end{array}$ & $\begin{array}{l}5.86^{* * *} \\
(5.57)\end{array}$ & $\begin{array}{c}0.83 \\
(1.00)\end{array}$ & $\begin{array}{l}3.94^{* * *} \\
(3.31)\end{array}$ \\
\hline IP & 99 & 2.62 & $\begin{array}{l}1.35^{* *} \\
(2.22)\end{array}$ & $\begin{array}{c}0.16 \\
(0.17)\end{array}$ & $\begin{array}{r}1.30^{*} \\
(1.81)\end{array}$ & $\begin{array}{l}-1.13 \\
(-1.09)\end{array}$ \\
\hline PMI & - & - & - & - & - & - \\
\hline RETAIL SALES & 25 & 2.39 & $\begin{array}{c}- \\
0.28 \\
(0.21)\end{array}$ & $\begin{array}{c}- \\
1.70 \\
(0.91)\end{array}$ & $\begin{array}{c}- \\
0.24 \\
(0.17)\end{array}$ & $\begin{array}{c}- \\
1.42 \\
(0.67)\end{array}$ \\
\hline TRADE BALANCE & 111 & 397 & $\begin{array}{l}-0.10 \\
(-0.17)\end{array}$ & $\begin{array}{c}-0.89 \\
(-0.93)\end{array}$ & $\begin{array}{c}0.81 \\
(1.11)\end{array}$ & $\begin{array}{l}-1.85^{*} \\
(-1.71)\end{array}$ \\
\hline GDP & 35 & 0.26 & $\begin{array}{r}1.80^{*} \\
(1.77)\end{array}$ & $\begin{array}{l}2.55 \\
(1.62)\end{array}$ & $\begin{array}{l}-0.58 \\
(-0.47)\end{array}$ & $\begin{array}{c}3.04^{*} \\
(1.71)\end{array}$ \\
\hline UNEMPL. RATE & 123 & 0.22 & $\begin{array}{c}0.11 \\
(0.19)\end{array}$ & $\begin{array}{r}1.52^{*} \\
(1.79)\end{array}$ & $\begin{array}{c}0.43 \\
(0.63)\end{array}$ & $\begin{array}{c}1.12 \\
(1.15)\end{array}$ \\
\hline $\begin{array}{l}\text { Number of obs. } \\
R^{2} \\
\text { adj. } R^{2}\end{array}$ & & & $\begin{array}{l}481 \\
12 \% \\
10 \%\end{array}$ & $\begin{array}{l}483 \\
9 \% \\
7 \%\end{array}$ & $\begin{array}{l}481 \\
1 \% \\
0 \%\end{array}$ & $\begin{array}{l}481 \\
5 \% \\
3 \%\end{array}$ \\
\hline $\begin{array}{l}\text { Wald-statistic } \\
\text { ( } p \text {-value) }\end{array}$ & & & $\begin{array}{c}62.33 \\
(0.00)\end{array}$ & $\begin{array}{c}38.98 \\
(0.00)\end{array}$ & $\begin{array}{c}6.01 \\
(0.54)\end{array}$ & $\begin{array}{l}20.45 \\
(0.01)\end{array}$ \\
\hline
\end{tabular}

Notes: The table shows results in columns three to six of regressing Chilean short-term and 1-year far-forward rates on several domestic macro news surprises for the full sample period October 2002 - April 2013 for Chile, including only those days on which at least one Chilean macroeconomic figure is released. See the notes to Table 1 for further details. 
Table 3: MeXiCO: Baseline Model (Full Sample: Jan-2003 - Apr-2013)

\begin{tabular}{|c|c|c|c|c|c|c|}
\hline variable & $\begin{array}{l}\text { number } \\
\text { of obs. }\end{array}$ & $\begin{array}{l}\text { stdev. } \\
\text { surprise }\end{array}$ & $\begin{array}{c}1-y r \\
\text { nominal rate }\end{array}$ & $\begin{array}{l}\text { 1-yr forward } \\
\text { nominal rate } \\
\text { ending } 7 \text { yrs }\end{array}$ & $\begin{array}{l}\text { 1-yr forward } \\
\text { real rate } \\
\text { ending } 7 \text { yrs }\end{array}$ & $\begin{array}{l}\text { 1-yr forward } \\
\text { infl. comp. } \\
\text { ending } 7 \text { yrs }\end{array}$ \\
\hline \multicolumn{7}{|l|}{ Macro News Surprises } \\
\hline POLICY RATE & 79 & - & $\begin{array}{l}0.60^{* * *} \\
(7.31)\end{array}$ & $\begin{array}{l}-0.16 \\
(-1.32)\end{array}$ & $\begin{array}{r}0.17^{*} \\
(1.75)\end{array}$ & $\begin{array}{l}-0.16 \\
(-1.48)\end{array}$ \\
\hline CPI & 97 & 0.06 & $\begin{array}{c}0.83 \\
(1.28)\end{array}$ & $\begin{array}{c}1.07 \\
(0.93)\end{array}$ & $\begin{array}{l}-0.94 \\
(-1.26)\end{array}$ & $\begin{array}{c}2.03^{*} \\
(1.94)\end{array}$ \\
\hline IP & 118 & 1.24 & $\begin{array}{l}1.10^{*} \\
(1.87)\end{array}$ & $\begin{array}{l}2.41^{* *} \\
(2.41)\end{array}$ & $\begin{array}{c}0.76 \\
(1.12)\end{array}$ & $\begin{array}{r}1.59^{*} \\
(1.74)\end{array}$ \\
\hline PMI & 41 & 1.32 & $\begin{array}{c}0.27 \\
(0.25)\end{array}$ & $\begin{array}{l}-1.08 \\
(-0.62)\end{array}$ & $\begin{array}{c}0.53 \\
(0.40)\end{array}$ & $\begin{array}{l}-1.15 \\
(-0.68)\end{array}$ \\
\hline RETAIL SALES & 119 & 1.78 & $\begin{array}{l}-0.04 \\
(-0.07)\end{array}$ & $\begin{array}{l}-0.17 \\
(-0.17)\end{array}$ & $\begin{array}{l}-0.87 \\
(-1.21)\end{array}$ & $\begin{array}{l}-0.28 \\
(-0.29)\end{array}$ \\
\hline TRADE BALANCE & 116 & 687 & $\begin{array}{c}0.00 \\
(-0.01)\end{array}$ & $\begin{array}{l}-0.69 \\
(-0.67)\end{array}$ & $\begin{array}{c}0.73 \\
(0.95)\end{array}$ & $\begin{array}{l}-0.60 \\
(-0.63)\end{array}$ \\
\hline GDP & 39 & 0.35 & $\begin{array}{l}-1.52 \\
(-1.43)\end{array}$ & $\begin{array}{l}-0.03 \\
(-0.02)\end{array}$ & $\begin{array}{c}0.21 \\
(0.18)\end{array}$ & $\begin{array}{l}-1.68 \\
(-0.93)\end{array}$ \\
\hline UNEMPL. RATE & 120 & 0.29 & $\begin{array}{c}0.09 \\
(0.15)\end{array}$ & $\begin{array}{l}-1.10 \\
(-1.08)\end{array}$ & $\begin{array}{c}0.30 \\
(0.42)\end{array}$ & $\begin{array}{c}-0.58 \\
(-0.62)\end{array}$ \\
\hline $\begin{array}{l}\text { Number of obs. } \\
R^{2} \\
\operatorname{adj} . R^{2}\end{array}$ & & & $\begin{array}{l}679 \\
8 \% \\
7 \%\end{array}$ & $\begin{array}{l}680 \\
2 \% \\
0 \%\end{array}$ & $\begin{array}{l}673 \\
1 \% \\
0 \%\end{array}$ & $\begin{array}{l}678 \\
2 \% \\
0 \%\end{array}$ \\
\hline $\begin{array}{l}\text { Wald-statistic } \\
\text { ( } p \text {-value) }\end{array}$ & & & $\begin{array}{c}61.48 \\
(0.00)\end{array}$ & $\begin{array}{l}10.22 \\
(0.25)\end{array}$ & $\begin{array}{c}8.70 \\
(0.37)\end{array}$ & $\begin{array}{l}10.98 \\
(0.20)\end{array}$ \\
\hline
\end{tabular}

Notes: The table shows results in columns three to six of regressing Mexican short-term and 1-year far-forward rates on several domestic macro news surprises for the full sample period January 2003 - April 2013 for Mexico, including only those days on which at least one Mexican macroeconomic figure is released. See the notes to Table 1 for further details. 
Table 4: Baseline Models with U.S. Surprises (Full Sample)

\begin{tabular}{|c|c|c|c|c|c|c|c|c|c|}
\hline \multirow[b]{2}{*}{ variable } & \multicolumn{3}{|c|}{ BRAZIL } & \multicolumn{3}{|c|}{ Chile } & \multicolumn{3}{|c|}{ MEXICO } \\
\hline & $\begin{array}{l}\text { stdev. } \\
\text { surpr. }\end{array}$ & $\begin{array}{c}1-y r \\
\text { nom. rate }\end{array}$ & $\begin{array}{l}\text { 1-yr fwd } \\
\text { infl. comp. } \\
\text { end. } 7 \text { yrs }\end{array}$ & $\begin{array}{l}\text { stdev. } \\
\text { surpr. }\end{array}$ & $\begin{array}{c}1-\text { yr } \\
\text { nom. rate }\end{array}$ & $\begin{array}{c}\text { 1-yr fwd } \\
\text { infl. comp. } \\
\text { end. } 10 \text { yrs }\end{array}$ & $\begin{array}{l}\text { stdev. } \\
\text { surpr. }\end{array}$ & $\begin{array}{c}1-y r \\
\text { nom. rate }\end{array}$ & $\begin{array}{l}\text { 1-yr fwd } \\
\text { infl. comp. } \\
\text { end. } 7 \text { yrs }\end{array}$ \\
\hline \multicolumn{10}{|c|}{ DOMESTIC Macro News Surprises } \\
\hline POLICY RATE & - & $0.30^{* * *}$ & 0.15 & - & $0.07^{*}$ & -0.03 & - & $0.55^{* * *}$ & -0.13 \\
\hline CPI & 0.06 & $2.54^{* * *}$ & 2.17 & 0.26 & $4.29^{* * *}$ & $4.30^{* * *}$ & 0.06 & 0.83 & $1.78^{*}$ \\
\hline IP & 1.09 & $3.45^{* * *}$ & $5.01^{* *}$ & 2.62 & $1.20^{* *}$ & -1.07 & 1.24 & 1.04 & $1.62^{*}$ \\
\hline PMI & - & - & - & - & - & - & 1.32 & 1.46 & -1.95 \\
\hline RETAIL SALES & 1.30 & $1.38^{*}$ & 2.27 & 2.39 & 0.32 & 1.38 & 1.78 & -0.02 & 0.14 \\
\hline TRADE BALANCE & 602 & -1.10 & $3.47^{*}$ & 397 & -0.08 & -1.69 & 687 & 0.01 & -0.64 \\
\hline GDP & 0.44 & $5.08^{* *}$ & 3.33 & 0.26 & $1.80^{* *}$ & 2.88 & 0.35 & -1.91 & -0.15 \\
\hline UNEMPL. RATE & 0.27 & $-2.05^{* * *}$ & -1.86 & 0.22 & 0.26 & 1.11 & 0.29 & 0.07 & -0.61 \\
\hline \multicolumn{10}{|l|}{ U.S. Macro News Surprises } \\
\hline POLICY RATE & - & $\begin{array}{c}0.33 \\
(1.33)\end{array}$ & $\begin{array}{c}0.52 \\
(0.88)\end{array}$ & - & $\begin{array}{c}0.07 \\
(0.51)\end{array}$ & $\begin{array}{c}0.11 \\
(0.36)\end{array}$ & - & $\begin{array}{c}0.18 \\
(0.39)\end{array}$ & $\begin{array}{c}0.49 \\
(1.23)\end{array}$ \\
\hline $\mathrm{CPI}$ & 0.17 & $\begin{array}{c}0.60 \\
(0.74)\end{array}$ & $\begin{array}{c}-0.42 \\
(-0.22)\end{array}$ & 0.17 & $\begin{array}{c}-0.18 \\
(-0.32)\end{array}$ & $\begin{array}{l}-2.18^{* *} \\
(-1.98)\end{array}$ & 0.17 & $\begin{array}{c}-0.14 \\
(-0.11)\end{array}$ & $\begin{array}{c}-2.05^{*} \\
(-1.94)\end{array}$ \\
\hline IP & 0.45 & $\begin{array}{c}0.31 \\
(0.34)\end{array}$ & $\begin{array}{r}-4.03^{*} \\
(-1.89)\end{array}$ & 0.41 & $\begin{array}{c}0.38 \\
(0.68)\end{array}$ & $\begin{array}{c}0.45 \\
(0.40)\end{array}$ & 0.41 & $\begin{array}{c}1.73 \\
(1.32)\end{array}$ & $\begin{array}{c}0.25 \\
(0.22)\end{array}$ \\
\hline PMI & 3.90 & $\begin{array}{c}-1.04 \\
(-1.36)\end{array}$ & $\begin{array}{c}2.08 \\
(1.14)\end{array}$ & 4.17 & $\begin{array}{c}0.15 \\
(0.32)\end{array}$ & $\begin{array}{c}0.10 \\
(0.10)\end{array}$ & 4.18 & $\begin{array}{c}-0.07 \\
(-0.06)\end{array}$ & $\begin{array}{c}0.73 \\
(0.74)\end{array}$ \\
\hline RETAIL SALES & 0.53 & $\begin{array}{l}-0.20 \\
(-0.27)\end{array}$ & $\begin{array}{c}0.85 \\
(0.45)\end{array}$ & 0.53 & $\begin{array}{c}-0.24 \\
(-0.47)\end{array}$ & $\begin{array}{c}0.48 \\
(0.47)\end{array}$ & 0.54 & $\begin{array}{l}-0.46 \\
(-0.40)\end{array}$ & $\begin{array}{c}1.21 \\
(1.23)\end{array}$ \\
\hline TRADE BALANCE & 3.64 & $\begin{array}{c}1.07 \\
(1.35)\end{array}$ & $\begin{array}{c}0.11 \\
(0.06)\end{array}$ & 3.64 & $\begin{array}{l}-1.01^{* *} \\
(-2.07)\end{array}$ & $\begin{array}{c}0.88 \\
(0.90)\end{array}$ & 3.49 & $\begin{array}{c}-1.25 \\
(-1.09)\end{array}$ & $\begin{array}{c}1.38 \\
(1.41)\end{array}$ \\
\hline GDP & 0.62 & $\begin{array}{c}0.95 \\
(0.73)\end{array}$ & $\begin{array}{l}-2.74 \\
(-0.88)\end{array}$ & 0.66 & $\begin{array}{c}0.22 \\
(0.25)\end{array}$ & $\begin{array}{c}0.23 \\
(0.13)\end{array}$ & 0.67 & $\begin{array}{c}1.24 \\
(0.63)\end{array}$ & $\begin{array}{c}1.99 \\
(1.19)\end{array}$ \\
\hline CONS. CONFIDENCE & 3.83 & $\begin{array}{c}0.22 \\
(0.29)\end{array}$ & $\begin{array}{c}-0.86 \\
(-0.45)\end{array}$ & 3.89 & $\begin{array}{c}0.34 \\
(0.71)\end{array}$ & $\begin{array}{l}2.52^{* * *} \\
(2.58)\end{array}$ & 3.90 & $\begin{array}{c}1.23 \\
(1.08)\end{array}$ & $\begin{array}{c}0.65 \\
(0.67)\end{array}$ \\
\hline INITIAL CLAIMS & 19 & $\begin{array}{c}-0.32 \\
(-0.80)\end{array}$ & $\begin{array}{c}1.25 \\
(1.37)\end{array}$ & 18 & $\begin{array}{c}0.19 \\
(0.79)\end{array}$ & $\begin{array}{c}0.21 \\
(0.42)\end{array}$ & 18 & $\begin{array}{c}-0.33 \\
(-0.58)\end{array}$ & $\begin{array}{c}-0.16 \\
(-0.33)\end{array}$ \\
\hline ISM & 1.91 & $\begin{array}{c}0.63 \\
(0.77)\end{array}$ & $\begin{array}{c}-1.57 \\
(-0.79)\end{array}$ & 2.02 & $\begin{array}{c}0.16 \\
(0.31)\end{array}$ & $\begin{array}{c}0.90 \\
(0.87)\end{array}$ & 1.99 & $\begin{array}{c}1.08 \\
(0.91)\end{array}$ & $\begin{array}{c}0.39 \\
(0.38)\end{array}$ \\
\hline NEW HOME SALES & 42 & $\begin{array}{c}0.03 \\
(0.04)\end{array}$ & $\begin{array}{c}0.70 \\
(0.40)\end{array}$ & 65 & $\begin{array}{c}0.35 \\
(0.72)\end{array}$ & $\begin{array}{l}-0.81 \\
(-0.83)\end{array}$ & 65 & $\begin{array}{c}0.51 \\
(0.44)\end{array}$ & $\begin{array}{l}-1.18 \\
(-1.21)\end{array}$ \\
\hline NONFARM PAYROLLS & 65 & $\begin{array}{c}0.14 \\
(0.18)\end{array}$ & $\begin{array}{c}1.14 \\
(0.60)\end{array}$ & 77 & $\begin{array}{c}0.54 \\
(1.09)\end{array}$ & $\begin{array}{l}3.35^{* * *} \\
(3.35)\end{array}$ & 78 & $\begin{array}{c}1.82 \\
(1.56)\end{array}$ & $\begin{array}{c}2.19^{* *} \\
(2.20)\end{array}$ \\
\hline UNEMPL. RATE & 0.17 & $\begin{array}{c}0.22 \\
(0.29)\end{array}$ & $\begin{array}{c}1.26 \\
(0.69)\end{array}$ & 0.15 & $\begin{array}{c}-0.31 \\
(-0.62)\end{array}$ & $\begin{array}{l}-1.99^{* *} \\
(-2.01)\end{array}$ & 0.15 & $\begin{array}{c}-0.67 \\
(-0.59)\end{array}$ & $\begin{array}{c}0.58 \\
(0.59)\end{array}$ \\
\hline $\begin{array}{l}\text { Number of obs. } \\
R^{2} \\
\text { adj. } R^{2}\end{array}$ & & $\begin{array}{l}969 \\
8 \% \\
6 \%\end{array}$ & $\begin{array}{l}968 \\
3 \% \\
1 \%\end{array}$ & & $\begin{array}{c}1544 \\
4 \% \\
3 \%\end{array}$ & $\begin{array}{c}1548 \\
3 \% \\
2 \%\end{array}$ & & $\begin{array}{l}1709 \\
8 \% \\
7 \%\end{array}$ & $\begin{array}{c}1709 \\
2 \% \\
0 \%\end{array}$ \\
\hline $\begin{array}{l}\text { Wald-statistic } \\
(p \text {-value })\end{array}$ & & $\begin{array}{l}80.74 \\
(0.00)\end{array}$ & $\begin{array}{l}24.57 \\
(0.22)\end{array}$ & & $\begin{array}{l}67.81 \\
(0.00)\end{array}$ & $\begin{array}{l}46.27 \\
(0.00)\end{array}$ & & $\begin{array}{l}27.79 \\
(0.15)\end{array}$ & $\begin{array}{l}27.43 \\
(0.16)\end{array}$ \\
\hline
\end{tabular}

Notes: The table shows full-sample regression results for Brazil (first three columns), Chile (middle three columns) and Mexico (final three columns), including only those days on which at least one domestic or U.S. macroeconomic figure is released. Full sample is July 2006 - April 2013 for Brazil, October 2002 - April 2013 for Chile, and January 2003 - April 2013 for Mexico. The one-standard deviation for U.S. surprises (in the first column for each country) is in basis points for the fed funds target rate, points for PMI, ISM, and consumer confidence; thousands for initial claims, new home sales, and nonfarm payrolls; billions of dollars for trade; and percentage points for all other surprises. See the notes to Table 1 for further details. 
Table 5: Baseline Models with Chinese Surprises (Full Sample)

\begin{tabular}{|c|c|c|c|c|c|c|c|c|c|}
\hline \multirow[b]{2}{*}{ variable } & \multicolumn{3}{|c|}{ BRAZIL } & \multicolumn{3}{|c|}{ Chile } & \multicolumn{3}{|c|}{ MEXICO } \\
\hline & $\begin{array}{l}\text { stdev. } \\
\text { surpr. }\end{array}$ & $\begin{array}{c}1-y r \\
\text { nom. rate }\end{array}$ & $\begin{array}{c}\text { 1-yr fwd } \\
\text { infl. comp. } \\
\text { end. } 7 \text { yrs }\end{array}$ & $\begin{array}{l}\text { stdev. } \\
\text { surpr. }\end{array}$ & $\begin{array}{c}1-y r \\
\text { nom. rate }\end{array}$ & $\begin{array}{c}\text { 1-yr fwd } \\
\text { infl. comp. } \\
\text { end. } 10 \text { yrs }\end{array}$ & $\begin{array}{l}\text { stdev. } \\
\text { surpr. }\end{array}$ & $\begin{array}{c}1-y r \\
\text { nom. rate }\end{array}$ & $\begin{array}{l}\text { 1-yr fwd } \\
\text { infl. comp. } \\
\text { end. } 7 \text { yrs }\end{array}$ \\
\hline \multicolumn{10}{|c|}{ DOMESTIC Macro News Surprises } \\
\hline POLICY RATE & - & $\overline{0.31} 1^{* * *}$ & 0.16 & - & $0.09^{* * *}$ & -0.03 & - & $0.61^{* * *}$ & -0.16 \\
\hline CPI & 0.06 & $2.45^{* * *}$ & 2.10 & 0.26 & $4.47^{* * *}$ & $3.98^{* * *}$ & 0.06 & 0.84 & $2.05^{* *}$ \\
\hline IP & 1.08 & $3.60^{* * *}$ & $5.06^{* *}$ & 2.62 & $1.35^{* *}$ & -1.07 & 1.24 & $1.02^{*}$ & $1.60^{*}$ \\
\hline PMI & - & - & - & - & - & - & 1.32 & 0.29 & -1.24 \\
\hline RETAIL SALES & 1.30 & $1.34^{*}$ & 2.18 & 2.39 & 0.30 & 1.29 & 1.78 & -0.04 & -0.26 \\
\hline TRADE BALANCE & 602 & -1.01 & 3.09 & 397 & -0.06 & $-1.94^{*}$ & 687 & -0.03 & -0.58 \\
\hline GDP & 0.44 & $5.01^{* *}$ & 3.63 & 0.26 & $1.80^{*}$ & $2.99^{*}$ & 0.35 & -1.49 & -1.60 \\
\hline UNEMPL. RATE & 0.27 & $-1.83^{* * *}$ & -1.04 & 0.22 & 0.11 & 1.15 & 0.29 & 0.08 & -0.57 \\
\hline \multicolumn{10}{|c|}{ CHINESE Macro News Surprises } \\
\hline CPI & 0.34 & $\begin{array}{c}1.14 \\
(1.45)\end{array}$ & $\begin{array}{c}-0.94 \\
(-0.47)\end{array}$ & 0.39 & $\begin{array}{c}0.62 \\
(1.03)\end{array}$ & $\begin{array}{c}-0.24 \\
(-0.23)\end{array}$ & 0.39 & $\begin{array}{c}0.70 \\
(1.06)\end{array}$ & $\begin{array}{c}-1.03 \\
(-1.04)\end{array}$ \\
\hline IP & 1.35 & $\begin{array}{c}-1.15 \\
(-1.26)\end{array}$ & $\begin{array}{l}5.14^{* *} \\
(2.22)\end{array}$ & 1.33 & $\begin{array}{l}-1.18 \\
(-1.49)\end{array}$ & $\begin{array}{c}0.40 \\
(0.33)\end{array}$ & 1.33 & $\begin{array}{l}-0.05 \\
(-0.07)\end{array}$ & $\begin{array}{c}1.87 \\
(1.60)\end{array}$ \\
\hline PMI & 0.89 & $\begin{array}{c}-0.04 \\
(-0.04)\end{array}$ & $\begin{array}{c}1.60 \\
(0.66)\end{array}$ & 0.89 & $\begin{array}{c}-0.38 \\
(-0.36)\end{array}$ & $\begin{array}{c}1.57 \\
(0.85)\end{array}$ & 0.89 & $\begin{array}{c}0.47 \\
(0.49)\end{array}$ & $\begin{array}{l}-0.69 \\
(-0.47)\end{array}$ \\
\hline RETAIL SALES & 1.18 & $\begin{array}{c}0.13 \\
(0.16)\end{array}$ & $\begin{array}{c}1.02 \\
(0.49)\end{array}$ & 1.17 & $\begin{array}{c}-1.06 \\
(-1.49)\end{array}$ & $\begin{array}{c}-0.68 \\
(-0.42)\end{array}$ & 1.17 & $\begin{array}{c}-0.59 \\
(-0.80)\end{array}$ & $\begin{array}{c}0.23 \\
(0.21)\end{array}$ \\
\hline TRADE BALANCE & 8.1 & $\begin{array}{c}-0.11 \\
(-0.13)\end{array}$ & $\begin{array}{c}-0.51 \\
(-0.26)\end{array}$ & 7.4 & $\begin{array}{c}0.18 \\
(0.30)\end{array}$ & $\begin{array}{c}-0.26 \\
(-0.24)\end{array}$ & 7.4 & $\begin{array}{c}-0.31 \\
(-0.46)\end{array}$ & $\begin{array}{c}0.13 \\
(0.13)\end{array}$ \\
\hline GDP & 0.34 & $\begin{array}{c}0.18 \\
(0.12)\end{array}$ & $\begin{array}{c}-6.90^{*} \\
(-1.87)\end{array}$ & 0.39 & $\begin{array}{c}1.31 \\
(1.24)\end{array}$ & $\begin{array}{c}0.88 \\
(0.48)\end{array}$ & 0.39 & $\begin{array}{l}1.07 \\
(0.93)\end{array}$ & $\begin{array}{c}-0.56 \\
(-0.31)\end{array}$ \\
\hline $\begin{array}{l}\text { Number of obs. } \\
R^{2} \\
\text { adj. } R^{2}\end{array}$ & & $\begin{array}{l}577 \\
14 \% \\
12 \%\end{array}$ & $\begin{array}{l}579 \\
4 \% \\
1 \%\end{array}$ & & $\begin{array}{c}681 \\
10 \% \\
8 \%\end{array}$ & $\begin{array}{l}681 \\
4 \% \\
2 \%\end{array}$ & & $\begin{array}{l}868 \\
7 \% \\
6 \%\end{array}$ & $\begin{array}{l}867 \\
2 \% \\
0 \%\end{array}$ \\
\hline $\begin{array}{l}\text { Wald-statistic } \\
\text { ( } p \text {-value })\end{array}$ & & $\begin{array}{l}89.26 \\
(0.00)\end{array}$ & $\begin{array}{l}19.61 \\
(0.11)\end{array}$ & & $\begin{array}{l}70.22 \\
(0.00)\end{array}$ & $\begin{array}{l}23.06 \\
(0.04)\end{array}$ & & $\begin{array}{c}65.62 \\
(0.00)\end{array}$ & $\begin{array}{l}15.80 \\
(0.33)\end{array}$ \\
\hline
\end{tabular}

Notes: The table shows full-sample regression results for Brazil (first three columns), Chile (middle three columns) and Mexico (final three columns), including only those days on which at least one domestic or Chinese macroeconomic figure is released. Full sample is July 2006 - April 2013 for Brazil, October 2002 - April 2013 for Chile, and January 2003 - April 2013 for Mexico. The one-standard deviation for Chinese surprises (in the first column for each country) is in points for PMI; billions of dollars for trade; and percentage points for all other surprises. See the notes to Table 1 for further details. 


\begin{tabular}{|c|c|c|c|c|c|c|c|c|c|c|c|c|c|c|c|c|}
\hline \multirow[b]{2}{*}{ week number: } & \multicolumn{4}{|c|}{ Month X } & \multicolumn{4}{|c|}{ Month X+1 } & \multicolumn{4}{|c|}{ Month X+2 } & \multicolumn{4}{|c|}{ Month X+3 } \\
\hline & 1 & 2 & 3 & 4 & 1 & 2 & 3 & 4 & 1 & 2 & 3 & 4 & 1 & 2 & 3 & 4 \\
\hline \multicolumn{17}{|l|}{ Brazil } \\
\hline PMI & - & - & - & - & $\mathrm{X}$ & - & - & - & - & - & - & - & - & - & - & - \\
\hline Trade Balance & - & - & - & - & $\mathrm{X}$ & - & - & - & - & - & - & - & - & - & - & - \\
\hline CPI (IPCA) & - & - & - & - & $\mathrm{X}$ & $\mathrm{X}$ & - & - & - & - & - & - & - & - & - & - \\
\hline IP & - & - & - & - & - & - & - & - & $\mathrm{X}$ & - & - & - & - & - & - & - \\
\hline Retail Sales & - & - & - & - & - & - & - & - & - & $\mathrm{X}$ & $\mathrm{X}$ & - & - & - & - & - \\
\hline Unempl. rate & - & - & - & - & - & - & - & - & - & - & $\mathrm{X}$ & $\mathrm{X}$ & - & - & - & - \\
\hline GDP & - & - & - & - & - & - & - & - & - & - & - & $\mathrm{X}$ & $\mathrm{X}$ & $\mathrm{X}$ & - & - \\
\hline
\end{tabular}

\section{Chile}

CPI

Trade Balance

Retail Sales

IP

Unempl. rate $\left(^{*}\right)$

GDP

\section{$\underline{\text { Mexico }}$}

PMI (IMEF)

CPI

Unempl. rate

Trade Balance

IP

GDP

Retail Sales

$$
\begin{array}{cccc}
X & X & - & - \\
X & X & - & - \\
- & - & - & X \\
- & - & - & X \\
- & - & - & X \\
- & - & - & -
\end{array}
$$

$$
\begin{array}{ll}
\mathrm{X} & - \\
\mathrm{X} & \mathrm{X}
\end{array}
$$

$$
\begin{array}{cccccccc}
- & - & - & - & X & X & - & - \\
- & - & - & - & - & - & X & X \\
- & - & - & - & - & - & - & X
\end{array}
$$

$$
\begin{array}{llllllll}
- & - & - & - & - & - & - & -
\end{array}
$$$$
\begin{array}{llllllll}
- & - & - & - & - & - & - & - \\
- & - & - & - & - & - & - & -
\end{array}
$$

\section{$\underline{\text { United States }}$}

Cons. Confidence

Initial Claims $(* *)$

PMI

Unempl. rate

Nonfarm Payrolls

Retail Sales

Trade Balance

CPI

IP

New Home Sales

GDP (Advance)

\section{China}

PMI

Trade Balance

CPI

IP

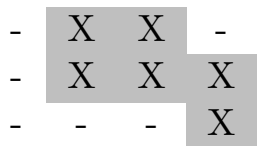

$$
\begin{array}{cccc}
\mathrm{X} & - & - & - \\
- & - & - & - \\
\mathrm{X} & - & - & - \\
\mathrm{X} & - & - & - \\
- & \mathrm{X} & - & - \\
- & \mathrm{X} & - & - \\
- & - & \mathrm{X} & - \\
- & - & \mathrm{X} & - \\
- & - & - & \mathrm{X} \\
- & - & - & \mathrm{X}
\end{array}
$$

Retail Sales

GDP

$\begin{array}{ccccccc}- & - & - & \mathrm{X} & \mathrm{X} & - & - \\ - & - & - & - & \mathrm{X} & - & - \\ - & - & - & - & \mathrm{X} & \mathrm{X} & - \\ - & - & - & - & \mathrm{X} & \mathrm{X} & - \\ - & - & - & - & \mathrm{X} & \mathrm{X} & - \\ - & - & - & - & - & - & \mathrm{X}\end{array}$

Notes: The table shows in which weeks different macro figures for month $X$ are released. Data is either released in the actual month (columns 1 through 4), the following month (columns 5 through 8), or in the months after that (columns 9 through 16). The timetable for U.S. data releases is from Andersson, Overby, and Sebestyén (2009).

(*) For Chile, the unemployment rate is the 3-month moving average rate. Before March 2009, unemployment was released the first week of month $\mathrm{X}+2$. Since then, the release has been in the last week of month $\mathrm{X}+1$.

$(* *)$ Initial claims for the U.S. are released weekly, with a release always reflecting claims for the week ending on the Friday prior to the release. 
Table 7: BRAZIL: Baseline Model (Pre-Crisis and Crisis Samples)

\begin{tabular}{|c|c|c|c|c|c|c|}
\hline \multirow[b]{2}{*}{ variable } & \multicolumn{3}{|c|}{ Pre-crisis: Jul-2006 - Jun-2007 } & \multicolumn{3}{|c|}{ Crisis: Jul-2007 - Apr-2013 } \\
\hline & $\begin{array}{l}\text { stdev. } \\
\text { surprise }\end{array}$ & $\begin{array}{c}1-y r \\
\text { nominal rate }\end{array}$ & $\begin{array}{l}\text { 1-yr forward } \\
\text { infl. comp. } \\
\text { ending } 7 \text { yrs }\end{array}$ & $\begin{array}{c}\text { stdev. } \\
\text { surprise }\end{array}$ & $\begin{array}{c}1-y r \\
\text { nominal rate }\end{array}$ & $\begin{array}{l}\text { 1-yr forward } \\
\text { infl. comp. } \\
\text { ending } 7 \text { yrs }\end{array}$ \\
\hline \multicolumn{7}{|l|}{ Macro News Surprises } \\
\hline POLICY RATE & - & $\begin{array}{r}0.52^{*} \\
(1.89)\end{array}$ & $\begin{array}{l}1.77^{* * *} \\
(3.18)\end{array}$ & - & $\begin{array}{l}0.20^{* * *} \\
(2.63)\end{array}$ & $\begin{array}{c}0.07 \\
(0.40)\end{array}$ \\
\hline $\mathrm{CPI}$ & 0.07 & $\begin{array}{r}3.17^{*} \\
(1.78)\end{array}$ & $\begin{array}{c}3.11 \\
(0.87)\end{array}$ & 0.06 & $\begin{array}{l}2.34^{* * *} \\
(2.77)\end{array}$ & $\begin{array}{c}1.93 \\
(0.87)\end{array}$ \\
\hline IP & 0.69 & $\begin{array}{c}2.55 \\
(1.54)\end{array}$ & $\begin{array}{c}3.83 \\
(1.15)\end{array}$ & 1.14 & $\begin{array}{l}3.64^{* * *} \\
(4.64)\end{array}$ & $\begin{array}{r}4.90^{*} \\
(1.88)\end{array}$ \\
\hline PMI & - & - & - & - & - & - \\
\hline RETAIL SALES & 1.82 & $\begin{array}{c}1.64 \\
(1.04)\end{array}$ & $\begin{array}{c}3.60 \\
(1.14)\end{array}$ & 1.18 & $\begin{array}{r}1.49^{*} \\
(1.80)\end{array}$ & $\begin{array}{c}1.92 \\
(0.93)\end{array}$ \\
\hline TRADE BALANCE & 470 & $\begin{array}{c}3.53 \\
(1.35)\end{array}$ & $\begin{array}{c}3.20 \\
(0.61)\end{array}$ & 622 & $\begin{array}{l}-1.02 \\
(-1.11)\end{array}$ & $\begin{array}{c}3.41 \\
(1.46)\end{array}$ \\
\hline GDP & 0.22 & $\begin{array}{c}5.92^{* *} \\
(1.99)\end{array}$ & $\begin{array}{l}-7.39 \\
(-1.24)\end{array}$ & 0.47 & $\begin{array}{c}2.82^{*} \\
(1.67)\end{array}$ & $\begin{array}{c}3.03 \\
(0.65)\end{array}$ \\
\hline UNEMPL. RATE & 0.34 & $\begin{array}{c}0.90 \\
(0.53)\end{array}$ & $\begin{array}{r}5.72^{*} \\
(1.69)\end{array}$ & 0.25 & $\begin{array}{l}-2.22^{* * *} \\
(-2.89)\end{array}$ & $\begin{array}{l}-2.39 \\
(-1.21)\end{array}$ \\
\hline $\begin{array}{l}\text { Number of obs. } \\
R^{2} \\
\text { adj. } R^{2}\end{array}$ & & $\begin{array}{c}66 \\
32 \% \\
22 \%\end{array}$ & $\begin{array}{c}66 \\
28 \% \\
18 \%\end{array}$ & & $\begin{array}{c}359 \\
13 \% \\
11 \%\end{array}$ & $\begin{array}{l}358 \\
3 \% \\
1 \%\end{array}$ \\
\hline $\begin{array}{l}F \text {-statistic } \\
(p \text {-value })\end{array}$ & & $\begin{array}{l}26.35 \\
(0.00)\end{array}$ & $\begin{array}{l}17.37 \\
(0.02)\end{array}$ & & $\begin{array}{l}50.71 \\
(0.00)\end{array}$ & $\begin{array}{c}9.29 \\
(0.23)\end{array}$ \\
\hline
\end{tabular}

Notes: The table shows regression results for Brazil for the pre-crisis sample period July 2006 - June 2007 (the three leftmost columns) and the crisis sample period July 2007 - April 2013 (the three rightmost columns), including only those days on which at least one Brazilian macroeconomic figure is released. See the notes to Table 1 for further details. 
Table 8: CHile: Baseline Model (Pre-Crisis and Crisis Samples)

\begin{tabular}{|c|c|c|c|c|c|c|}
\hline \multirow[b]{2}{*}{ variable } & \multicolumn{3}{|c|}{ Pre-crisis: Jul-2006 - Jun-2007 } & \multicolumn{3}{|c|}{ Crisis: Jul-2007 - Apr-2013 } \\
\hline & $\begin{array}{l}\text { stdev. } \\
\text { surprise }\end{array}$ & $\begin{array}{c}1-y r \\
\text { nominal rate }\end{array}$ & $\begin{array}{l}\text { 1-yr forward } \\
\text { infl. comp. } \\
\text { ending } 7 \text { yrs }\end{array}$ & $\begin{array}{c}\text { stdev. } \\
\text { surprise }\end{array}$ & $\begin{array}{c}1-y r \\
\text { nominal rate }\end{array}$ & $\begin{array}{l}\text { 1-yr forward } \\
\text { infl. comp. } \\
\text { ending } 7 \text { yrs }\end{array}$ \\
\hline \multicolumn{7}{|l|}{ Macro News Surprises } \\
\hline POLICY RATE & - & $\begin{array}{c}0.03 \\
(0.69)\end{array}$ & $\begin{array}{c}0.14 \\
(1.01)\end{array}$ & - & $\begin{array}{l}0.12^{\text {*** }} \\
(2.81)\end{array}$ & $\begin{array}{l}-0.06 \\
(-1.27)\end{array}$ \\
\hline $\mathrm{CPI}$ & 0.20 & $\begin{array}{c}0.43 \\
(0.49)\end{array}$ & $\begin{array}{c}4.84^{*} \\
(1.92)\end{array}$ & 0.28 & $\begin{array}{l}5.49^{* * *} \\
(5.90)\end{array}$ & $\begin{array}{c}3.75^{* * *} \\
(2.90)\end{array}$ \\
\hline IP & 2.16 & $\begin{array}{l}1.73^{* *} \\
(2.43)\end{array}$ & $\begin{array}{l}-3.40^{*} \\
(-1.66)\end{array}$ & 2.81 & $\begin{array}{l}1.78^{* *} \\
(2.09)\end{array}$ & $\begin{array}{c}-0.69 \\
(-0.59)\end{array}$ \\
\hline PMI & - & $\begin{array}{l}- \\
-\end{array}$ & - & - & - & - \\
\hline RETAIL SALES & - & $\begin{array}{l}- \\
-\end{array}$ & - & 2.27 & $\begin{array}{c}0.38 \\
(0.26)\end{array}$ & $\begin{array}{c}0.65 \\
(0.32)\end{array}$ \\
\hline TRADE BALANCE & 214 & $\begin{array}{c}1.16^{*} \\
(1.88)\end{array}$ & $\begin{array}{l}-1.78 \\
(-1.00)\end{array}$ & 478 & $\begin{array}{l}-0.47 \\
(-0.51)\end{array}$ & $\begin{array}{l}-2.48^{*} \\
(-1.86)\end{array}$ \\
\hline GDP & 0.24 & $\begin{array}{c}1.69 \\
(1.47)\end{array}$ & $\begin{array}{c}4.95 \\
(1.50)\end{array}$ & 0.28 & $\begin{array}{c}1.89 \\
(1.24)\end{array}$ & $\begin{array}{c}2.21 \\
(1.06)\end{array}$ \\
\hline UNEMPL. RATE & 0.20 & $\begin{array}{c}0.22 \\
(0.40)\end{array}$ & $\begin{array}{l}4.40^{* * *} \\
(2.80)\end{array}$ & 0.23 & $\begin{array}{c}0.41 \\
(0.46)\end{array}$ & $\begin{array}{l}-0.55 \\
(-0.46)\end{array}$ \\
\hline $\begin{array}{l}\text { Number of obs. } \\
R^{2} \\
\text { adj. } R^{2}\end{array}$ & & $\begin{array}{l}192 \\
7 \% \\
3 \%\end{array}$ & $\begin{array}{l}191 \\
9 \% \\
6 \%\end{array}$ & & $\begin{array}{l}291 \\
15 \% \\
13 \%\end{array}$ & $\begin{array}{l}290 \\
5 \% \\
3 \%\end{array}$ \\
\hline $\begin{array}{l}\text { Wald-statistic } \\
(p \text {-value })\end{array}$ & & $\begin{array}{l}12.74 \\
(0.05)\end{array}$ & $\begin{array}{l}17.82 \\
(0.01)\end{array}$ & & $\begin{array}{l}49.91 \\
(0.00)\end{array}$ & $\begin{array}{l}15.46 \\
(0.03)\end{array}$ \\
\hline
\end{tabular}

Notes: The table shows regression results for Chile for the pre-crisis sample period October 2002 - June 2007 (the three leftmost columns) and the crisis sample period July 2007 - April 2013 (the three rightmost columns), including only those days on which at least one Chilean macroeconomic figure is released. See the notes to Table 1 for further details. 
Table 9: MeXiCO: Baseline Model (Pre-Crisis and Crisis Samples)

\begin{tabular}{|c|c|c|c|c|c|c|}
\hline \multirow[b]{2}{*}{ variable } & \multicolumn{3}{|c|}{ Pre-crisis: Jul-2006 - Jun-2007 } & \multicolumn{3}{|c|}{ Crisis: Jul-2007 - Apr-2013 } \\
\hline & $\begin{array}{l}\text { stdev. } \\
\text { surprise }\end{array}$ & $\begin{array}{c}1-y r \\
\text { nominal rate }\end{array}$ & $\begin{array}{l}\text { 1-yr forward } \\
\text { infl. comp. } \\
\text { ending } 7 \text { yrs }\end{array}$ & $\begin{array}{c}\text { stdev. } \\
\text { surprise }\end{array}$ & $\begin{array}{c}1-y r \\
\text { nominal rate }\end{array}$ & $\begin{array}{l}\text { 1-yr forward } \\
\text { infl. comp. } \\
\text { ending } 7 \text { yrs }\end{array}$ \\
\hline \multicolumn{7}{|l|}{ Macro News Surprises } \\
\hline POLICY RATE & - & $\begin{array}{l}0.68^{* *} \\
(2.18)\end{array}$ & $\begin{array}{c}0.32 \\
(0.86)\end{array}$ & - & $\begin{array}{l}0.62^{* * *} \\
(7.43)\end{array}$ & $\begin{array}{l}-0.19^{* *} \\
(-2.04)\end{array}$ \\
\hline CPI & 0.07 & $\begin{array}{l}1.07 \\
(0.75)\end{array}$ & $\begin{array}{c}2.97 \\
(1.25)\end{array}$ & 0.06 & $\begin{array}{c}0.73 \\
(1.11)\end{array}$ & $\begin{array}{c}1.60 \\
(1.61)\end{array}$ \\
\hline IP & 1.23 & $\begin{array}{l}2.04^{* *} \\
(2.01)\end{array}$ & $\begin{array}{c}2.56 \\
(1.52)\end{array}$ & 1.25 & $\begin{array}{c}0.25 \\
(0.36)\end{array}$ & $\begin{array}{c}0.88 \\
(0.90)\end{array}$ \\
\hline PMI & - & - & - & 1.32 & $\begin{array}{c}0.28 \\
(0.31)\end{array}$ & $\begin{array}{l}-1.14 \\
(-0.87)\end{array}$ \\
\hline RETAIL SALES & 1.81 & $\begin{array}{c}-1.72 \\
(-1.57)\end{array}$ & $\begin{array}{c}0.09 \\
(0.05)\end{array}$ & 1.77 & $\begin{array}{l}1.31^{*} \\
(1.96)\end{array}$ & $\begin{array}{c}0.13 \\
(0.13)\end{array}$ \\
\hline TRADE BALANCE & 443 & $\begin{array}{c}0.88 \\
(0.79)\end{array}$ & $\begin{array}{c}1.03 \\
(0.53)\end{array}$ & 816 & $\begin{array}{l}-0.33 \\
(-0.50)\end{array}$ & $\begin{array}{c}-0.86 \\
(-0.90)\end{array}$ \\
\hline GDP & 0.37 & $\begin{array}{l}-4.53^{* *} \\
(-2.37)\end{array}$ & $\begin{array}{l}-2.66 \\
(-0.67)\end{array}$ & 0.34 & $\begin{array}{c}1.14 \\
(0.94)\end{array}$ & $\begin{array}{l}-1.15 \\
(-0.66)\end{array}$ \\
\hline UNEMPL. RATE & 0.28 & $\begin{array}{l}-0.07 \\
(-0.07)\end{array}$ & $\begin{array}{l}-0.60 \\
(-0.34)\end{array}$ & 0.29 & $\begin{array}{c}0.18 \\
(0.27)\end{array}$ & $\begin{array}{l}-1.06 \\
(-1.05)\end{array}$ \\
\hline $\begin{array}{l}\text { Number of obs. } \\
R^{2} \\
\text { adj. } R^{2}\end{array}$ & & $\begin{array}{l}263 \\
7 \% \\
4 \%\end{array}$ & $\begin{array}{l}262 \\
3 \% \\
0 \%\end{array}$ & & $\begin{array}{l}414 \\
13 \% \\
11 \%\end{array}$ & $\begin{array}{l}414 \\
3 \% \\
0 \%\end{array}$ \\
\hline $\begin{array}{l}\text { Wald-statistic } \\
\text { ( } p \text {-value })\end{array}$ & & $\begin{array}{l}18.06 \\
(0.01)\end{array}$ & $\begin{array}{c}5.39 \\
(0.61)\end{array}$ & & $\begin{array}{l}61.99 \\
(0.00)\end{array}$ & $\begin{array}{l}10.37 \\
(0.24)\end{array}$ \\
\hline
\end{tabular}

Notes: The table shows regression results for Mexico for the pre-crisis sample period January 2003 - June 2007 (the three leftmost columns) and the crisis sample period July 2007 - April 2013 (the three rightmost columns), including only those days on which at least one Mexican macroeconomic figure is released. See the notes to Table 1 for further details. 
Figure 1: Brazil: Inflation, SURVEy MEASUREs, AND FORWARD INFLATION COMPENSATION

\section{A. Inflation}

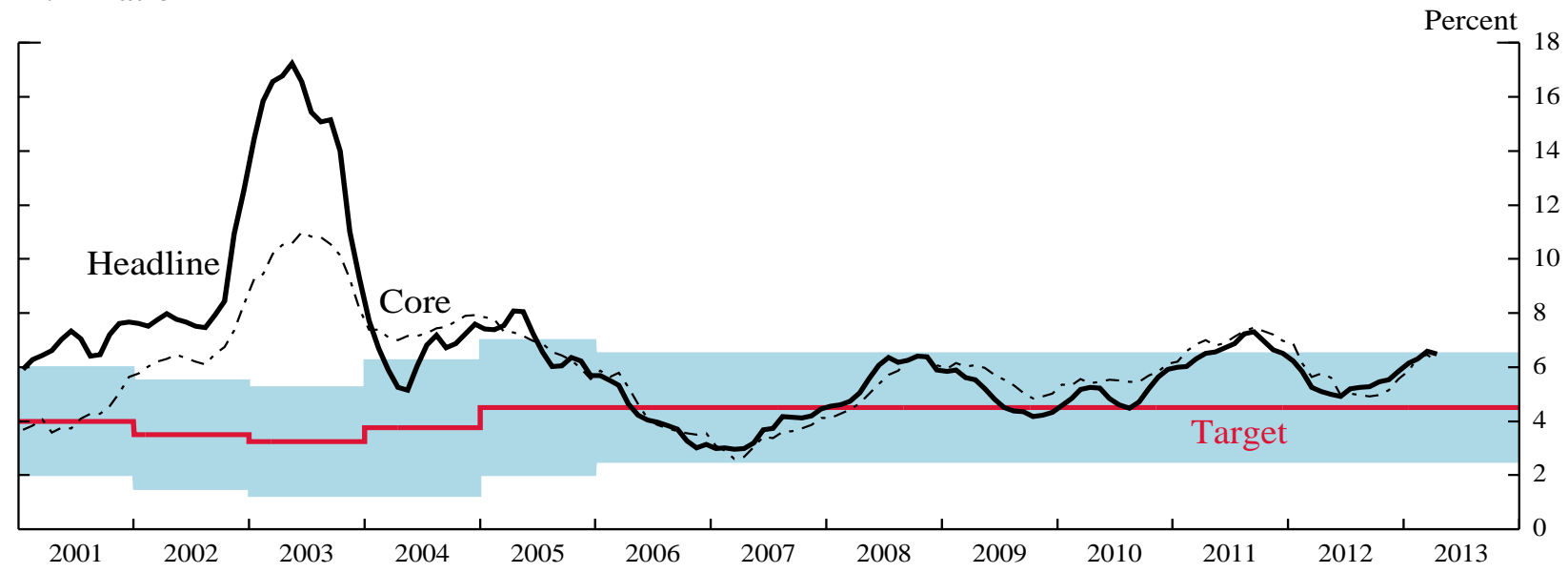

\section{B. Long-term Inflation Expectations}

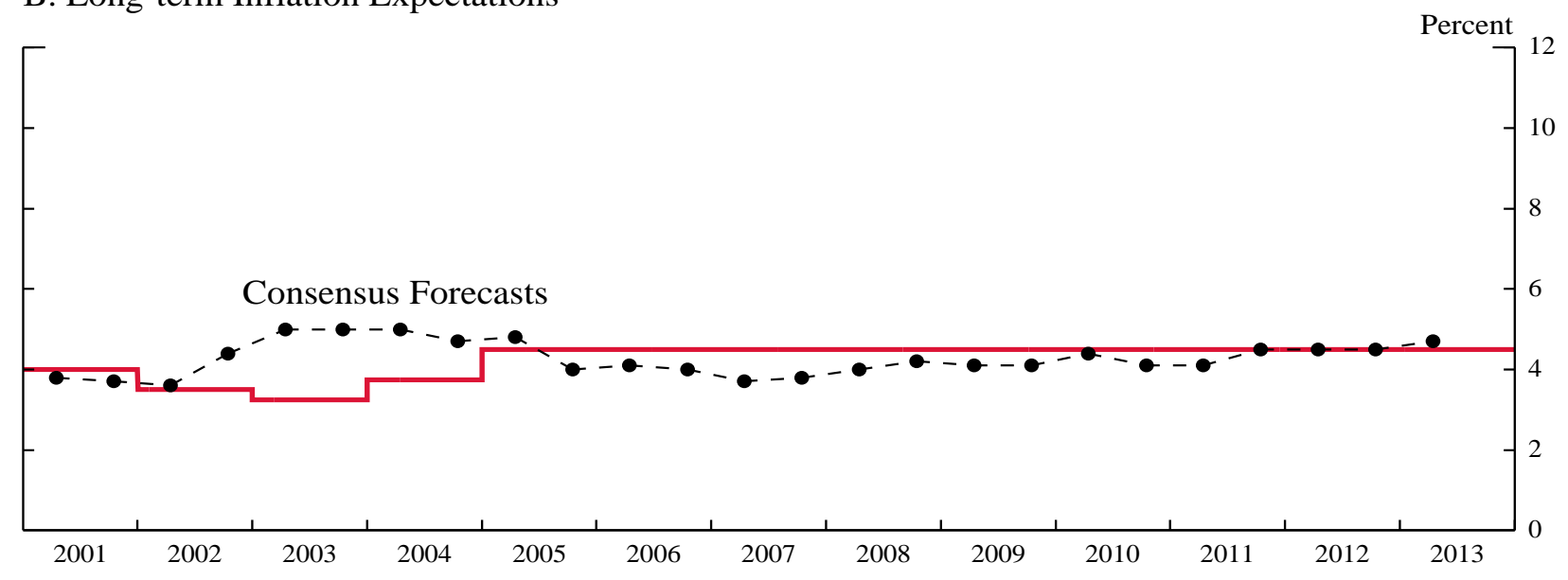

C. 1-Year Forward Inflation Compensation Ending in 7 Years

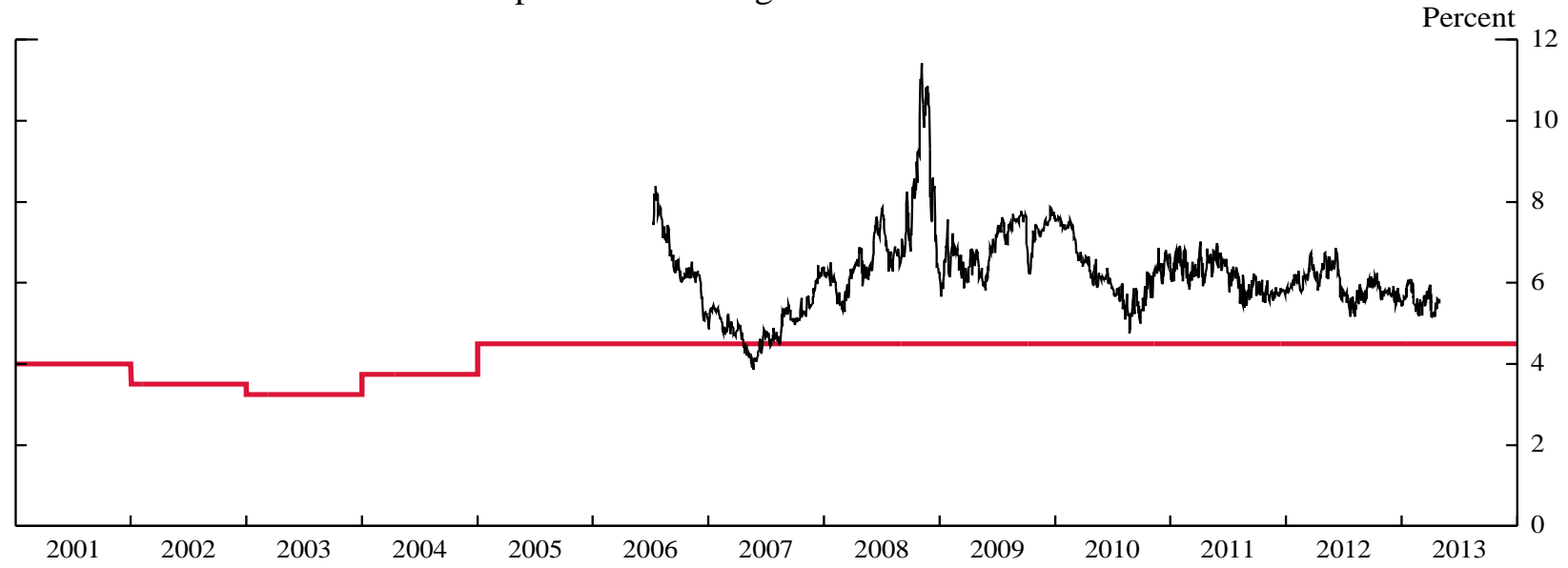

Notes: The figure presents realized inflation, expected inflation from Consensus Forecasts' bi-annual survey of longterm inflation expectations, and our estimated far-forward inflation compensation measure for Brazil. Panel A displays 12-month realized headline and core CPI and the inflation target. The tolerance interval for the inflation target is shown by the shaded area. Panel B displays the inflation target and the average of the responses from Consensus Forecasts' survey of inflation expectations for the forecast horizon of 6 to 10 years in the future. Panel C displays 1-year forward inflation compensation ending in 7 years along with the inflation target. 
Figure 2: Chile: Inflation, SURVEy MEASUREs, AND FORWARD Inflation COMPENSATion

A. Inflation

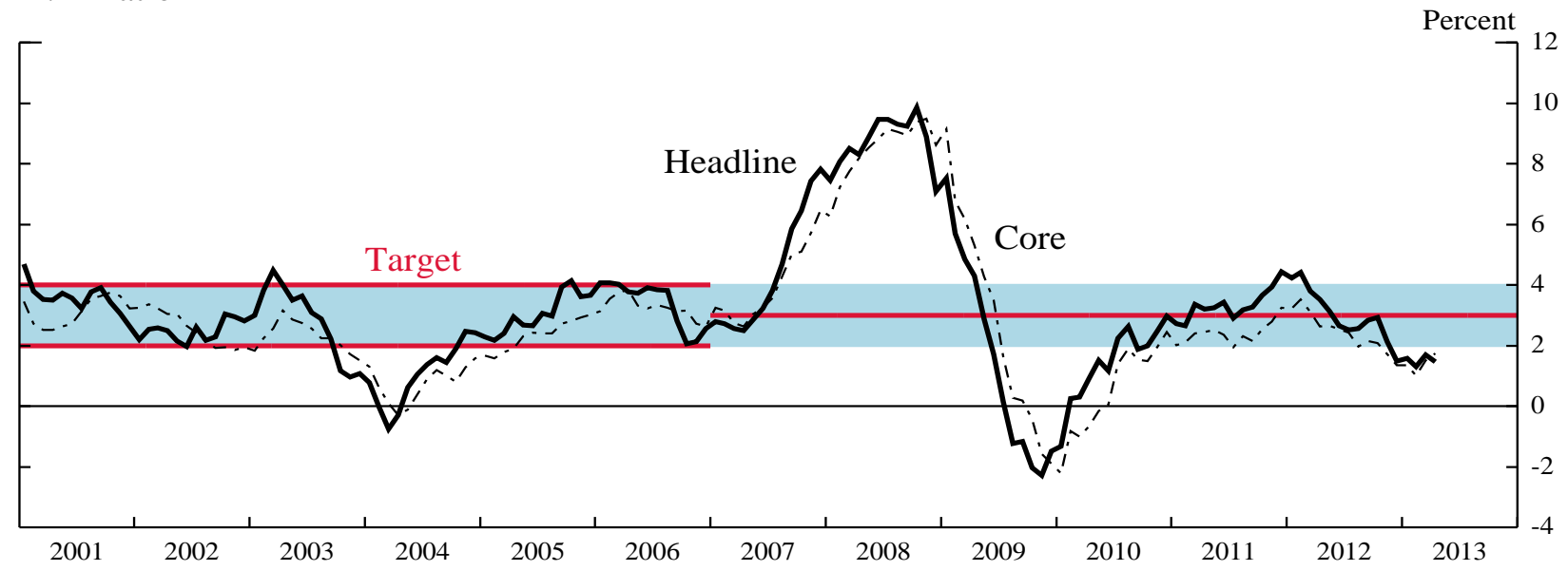

B. Medium- and Long-term Inflation Expectations

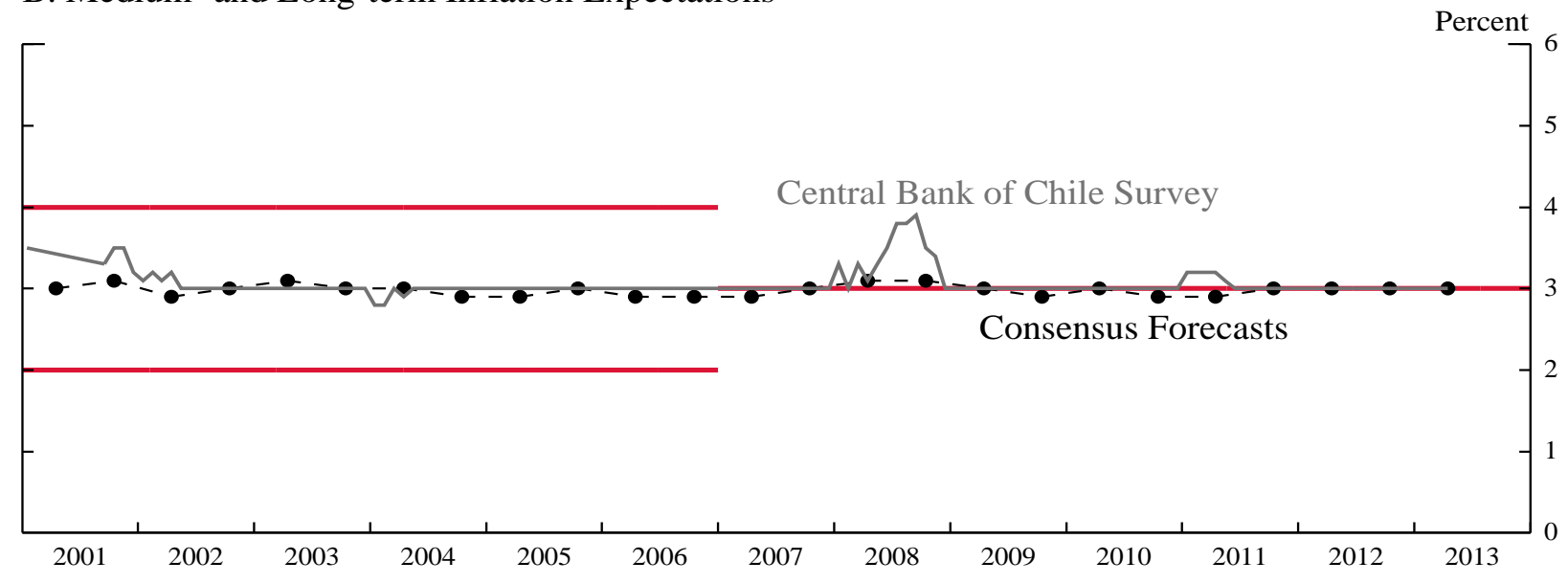

C. 1-Year Forward Inflation Compensation Ending in 10 Years

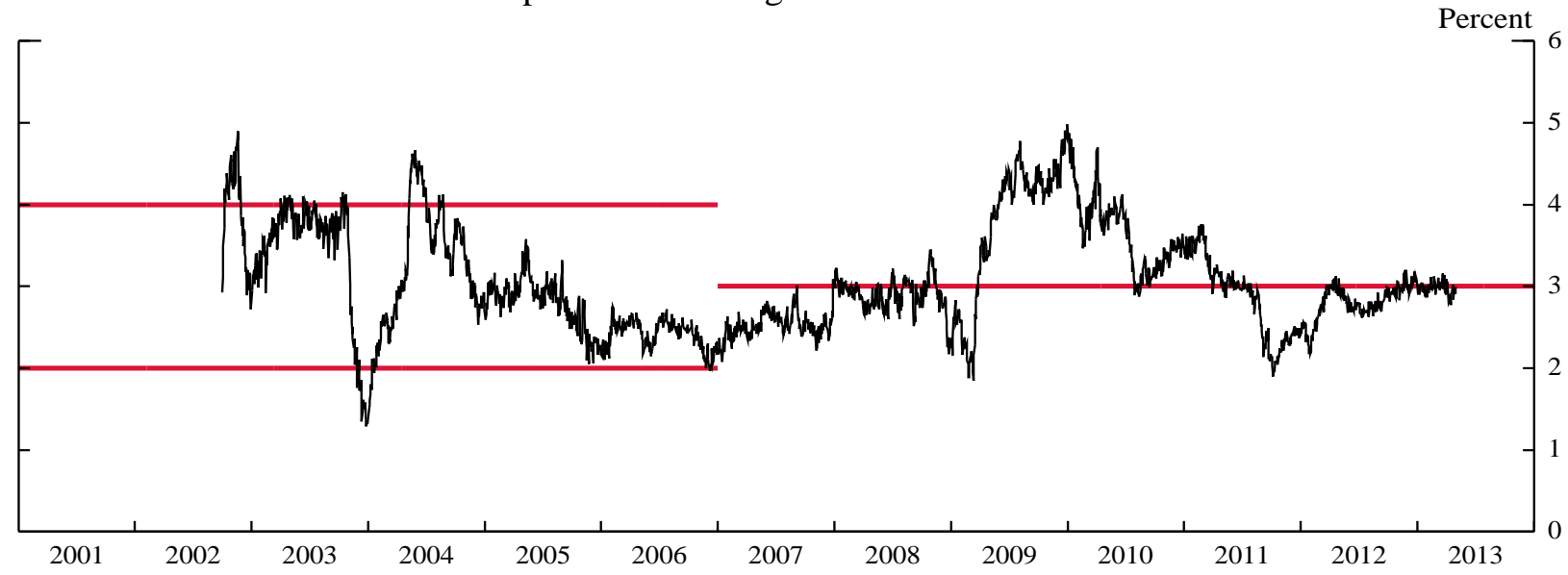

Notes: The figure presents realized inflation, measures of expected inflation from Consensus Forecasts and the Central Bank of Chile surveys, and our estimated far-forward inflation compensation measure for Chile. Panel A displays 12-month realized headline and core CPI, the inflation target, and the tolerance interval around this target. Note that before 2007 the inflation target was an interval of 2 to 4 percent. Panel B displays the inflation target, the average of the responses from the Consensus Forecasts' survey of long-term inflation expectations, and the median expectation of 12-month inflation ending 23 months in the future from the Central Bank of Chile's monthly survey of forecasters. Panel $\mathrm{C}$ displays 1-year forward inflation compensation ending in 10 years along with the inflation target. 
Figure 3: MEXico: Inflation, SURVEy MEASURES, AND FORWARD INFLATION COMPENSATION

A. Inflation

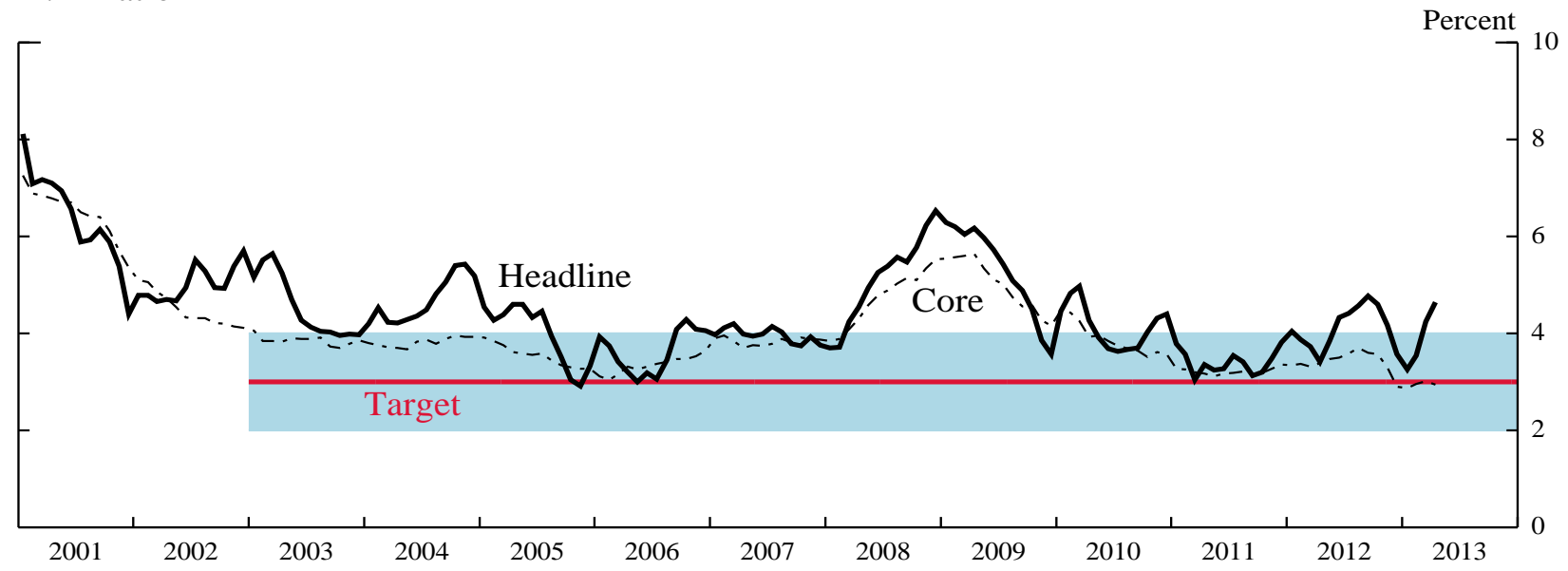

B. Long-term Inflation Expectations

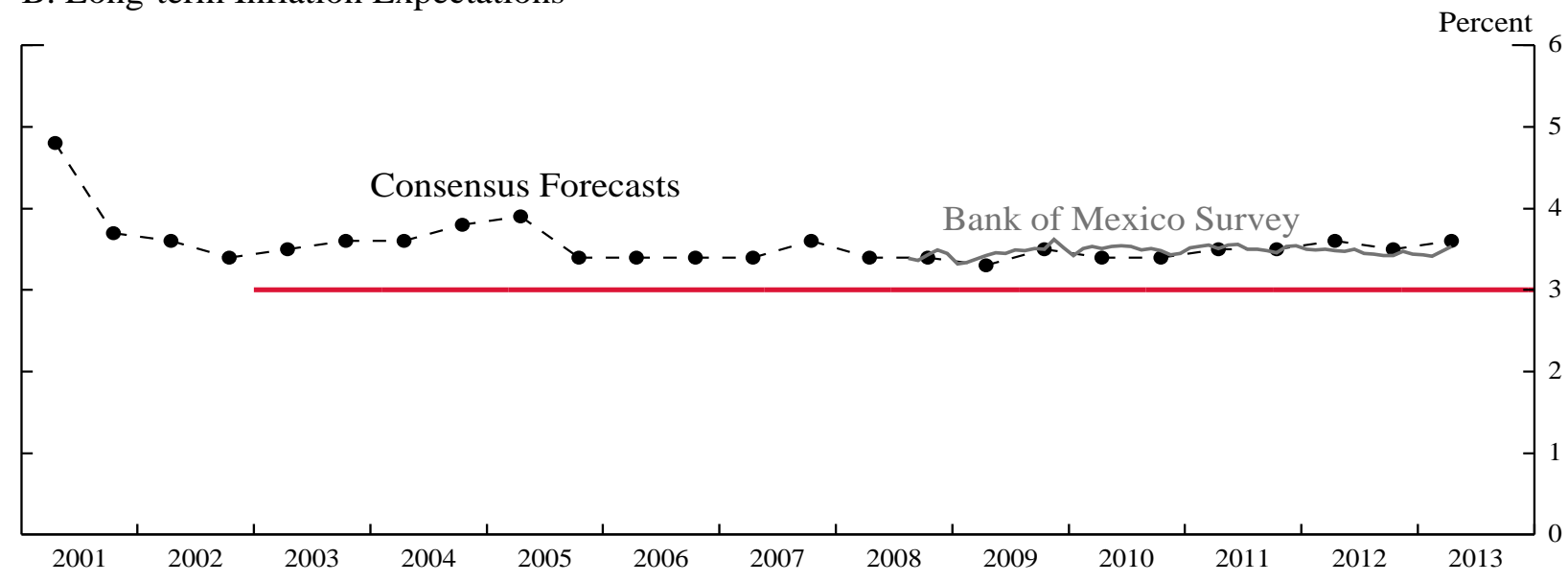

C. 1-Year Forward Inflation Compensation Ending in 7 Years

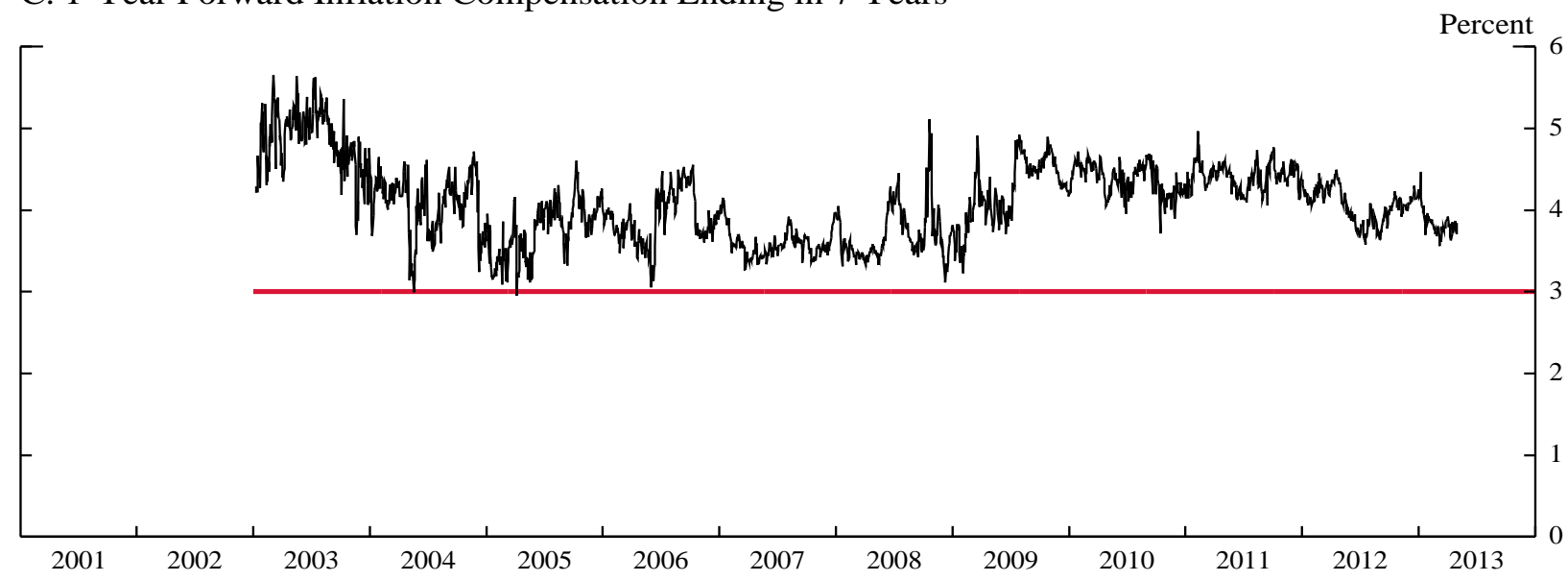

Notes: The figure presents realized inflation, measures of expected inflation from Consensus Forecasts and the Bank of Mexico surveys, and our estimated far-forward inflation compensation measure for Mexico. Panel A displays 12month realized headline and core CPI, the, inflation target, and the tolerance interval around this target. Panel B displays the inflation target, the average of the responses from the Consensus Forecasts survey of long-term inflation expectations, and the average of the responses for expected inflation for the forecast horizon of 5 to 8 years in the future from the Bank of Mexico's monthly survey of analysts' expectations. Panel C displays 1-year forward inflation compensation ending in 7 years along with the inflation target. 
Figure 4: Brazil: Central Bank of Brazil's Survey of Inflation Expectations

A. Average

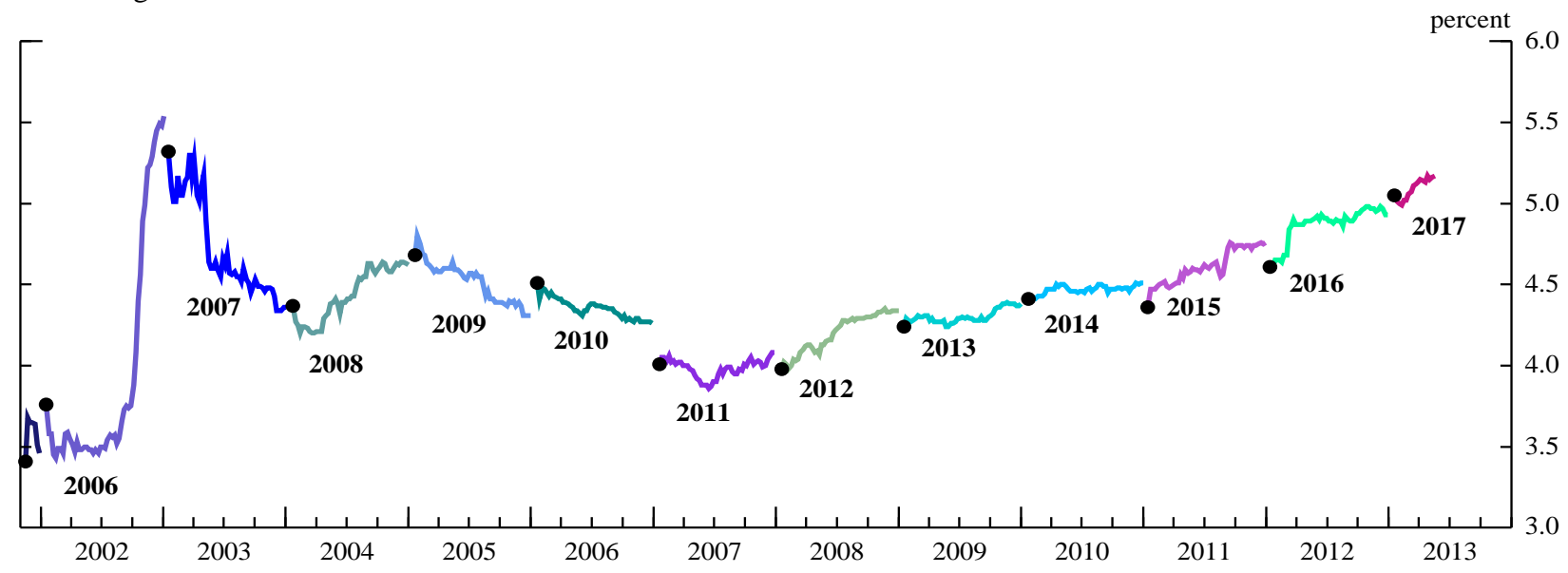

B. Median

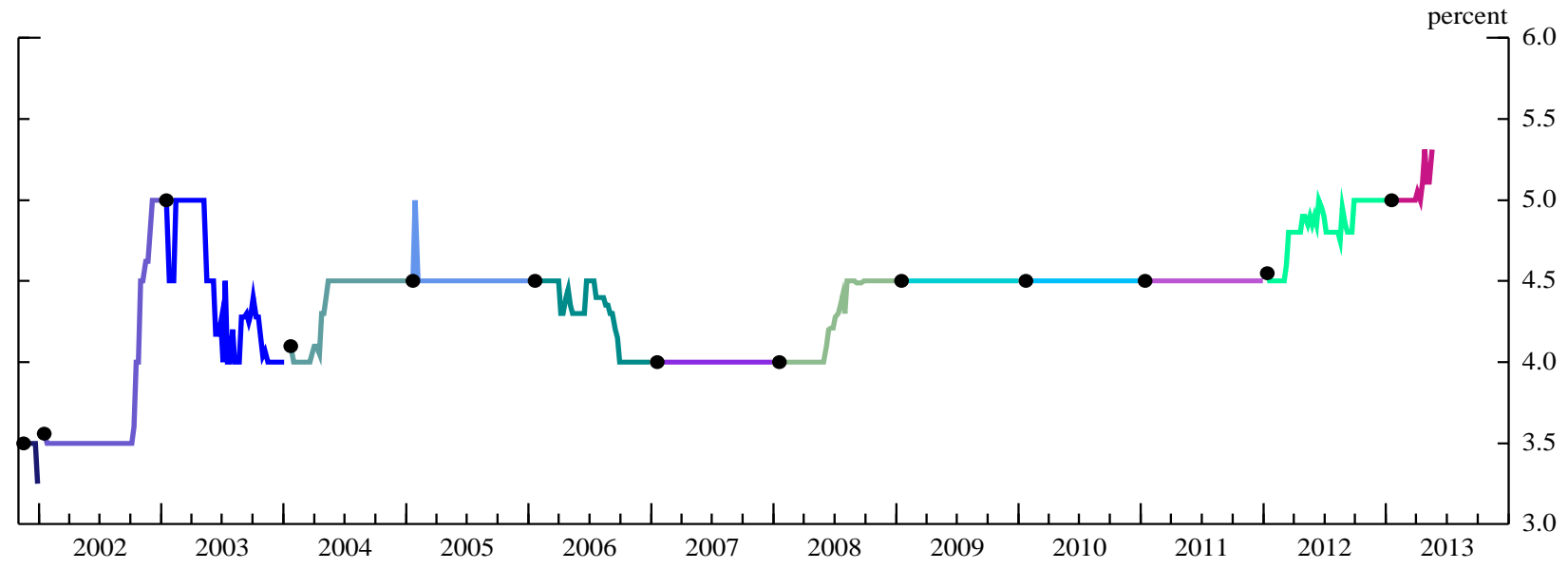

C. Standard Deviation

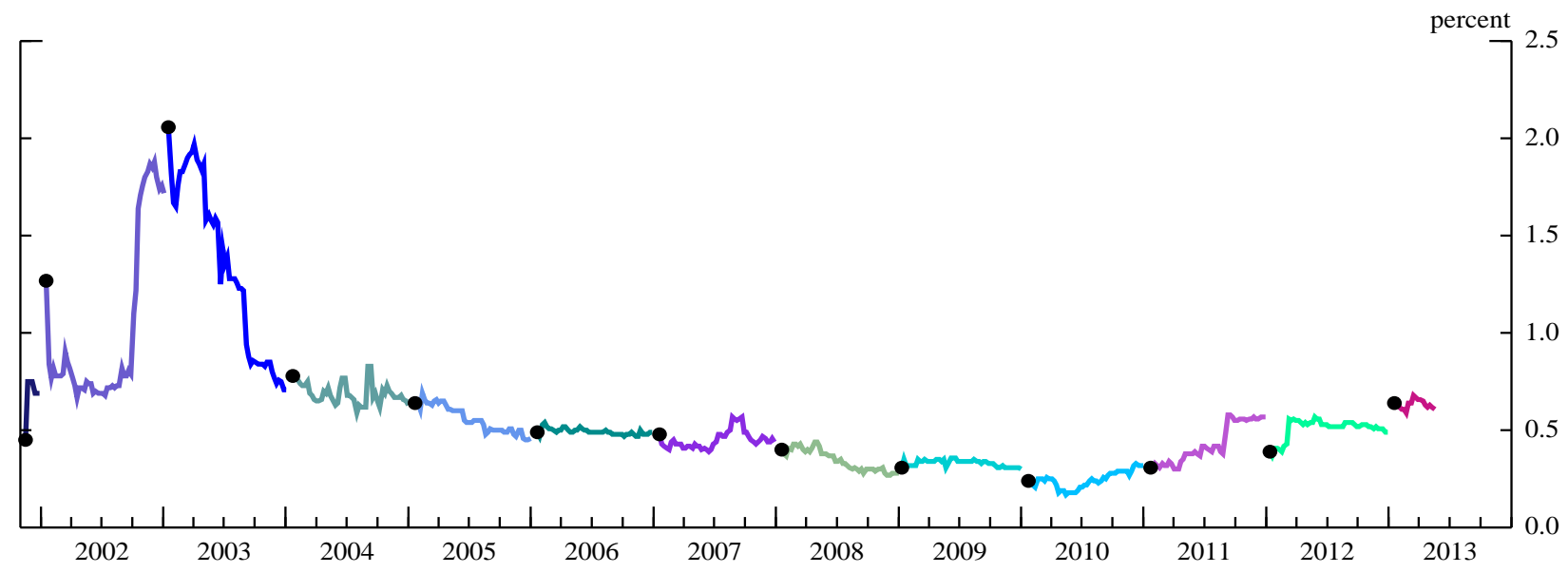

Notes: The figure displays the evolution of medium- to long-term inflation expectations from the Central Bank of Brazil's weekly survey of professional forecasters between November 2001 and April 2013. Panels A and B depict the mean and median of respondents' forecasts of headline inflation (the 12-month percentage change in the ICPA). Participants are asked to forecast inflation for the next few calendar years. The chart plots the forecast that is furthest in the future at the time of the survey. The black dots correspond to the weeks in which the inflation forecasts are rolled forward by one year, and at that time, the forecasts are for 12-month inflation ending five years in the future. The forecast period gradually shrinks as the year progresses so that by December, the forecasts are for 12-month inflation ending four years in the future. Panel $\mathrm{C}$ displays the standard deviation of respondents forecasts and is constructed in an analogous manner. There are gaps in the panels because the forecast period is rolled forward at different times (although always in January) and because we discard the first week of each years results. 
Figure 5: ZERO CURVE ESTIMATION: OUTSTANDING BONDS AND LONGEST-MATURITY BOND

\section{A. Brazil: Number of Bonds}

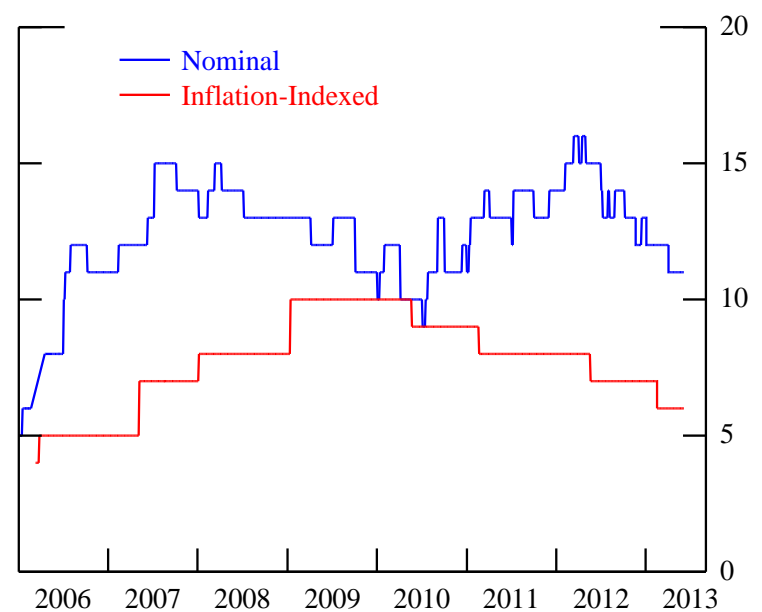

\section{Brazil: Maturity of Longest-Dated Bond}

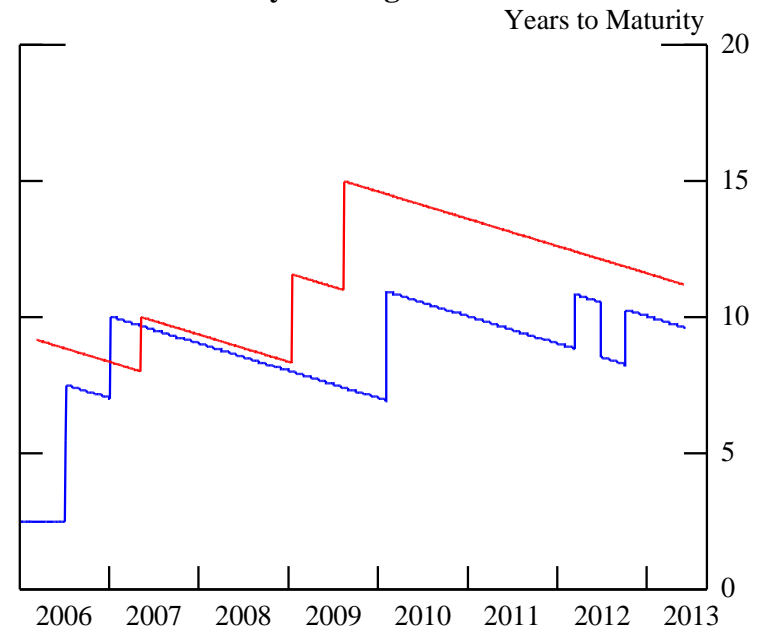

\section{B. Mexico: Number of Bonds}

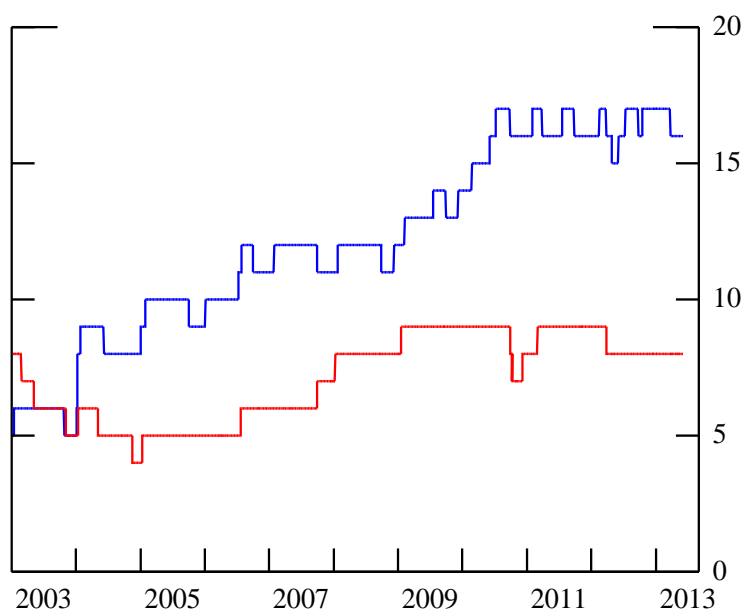

\section{Mexico: Maturity of Longest-Dated Bond}

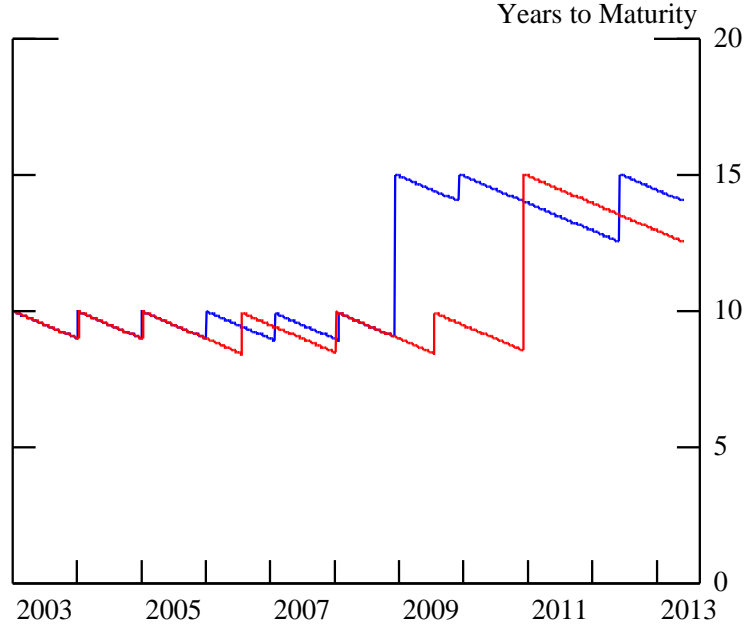

Notes: The figure presents indicators of the number and maturity of bonds used in the construction of the nominal and real zero-coupon curves from prices on nominal and inflation-linked sovereign bonds for Brazil (the left-hand-side panels) and Mexico (the right-hand-side panels) using the Nelson and Siegel (1987) model. Panels A and B display the number of nominal and inflation-indexed bonds that were used in the estimation on any given day (the blue and red lines, respectively). Panels $\mathrm{C}$ and $\mathrm{D}$ display the longest residual-maturity nominal and inflation-indexed bond that was used in the estimation of the zero-coupon curves. Note that in the estimation we only include bonds with residual maturities between three months and fifteen years. No indicators are shown for Chile, as we obtained zero curve estimates directly from RiskAmerica. 
Figure 6: BOND PRICE FITTING ERRORS

\section{A. Brazil: Nominal Bonds}

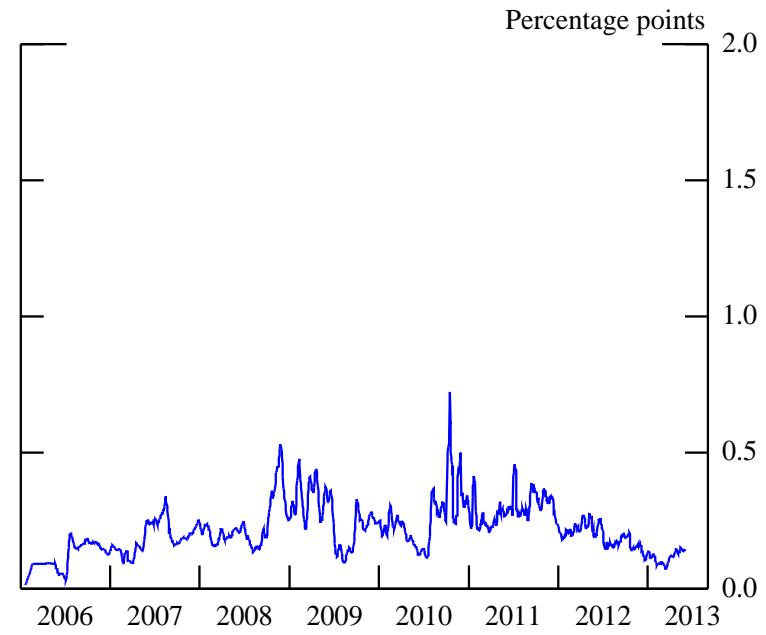

\section{Brazil: Inflation-Indexed Bonds}

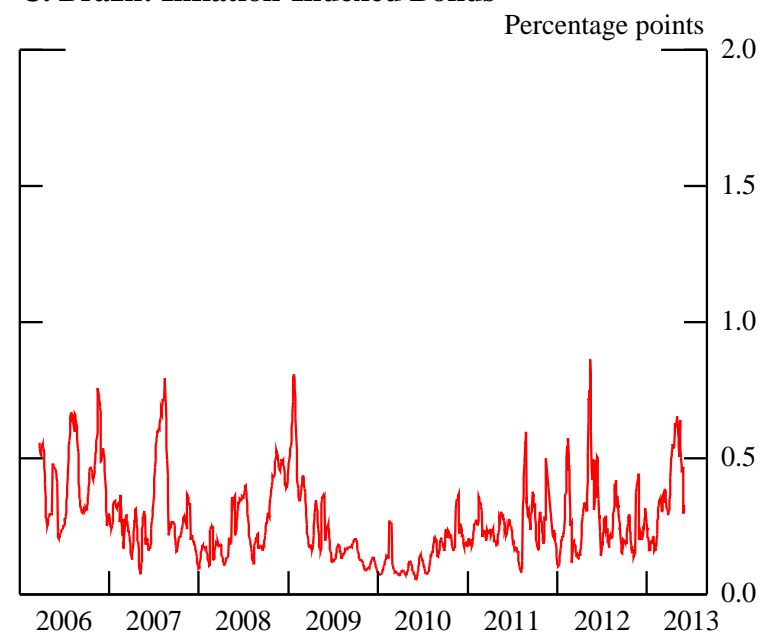

\section{B. Mexico: Nominal Bonds}

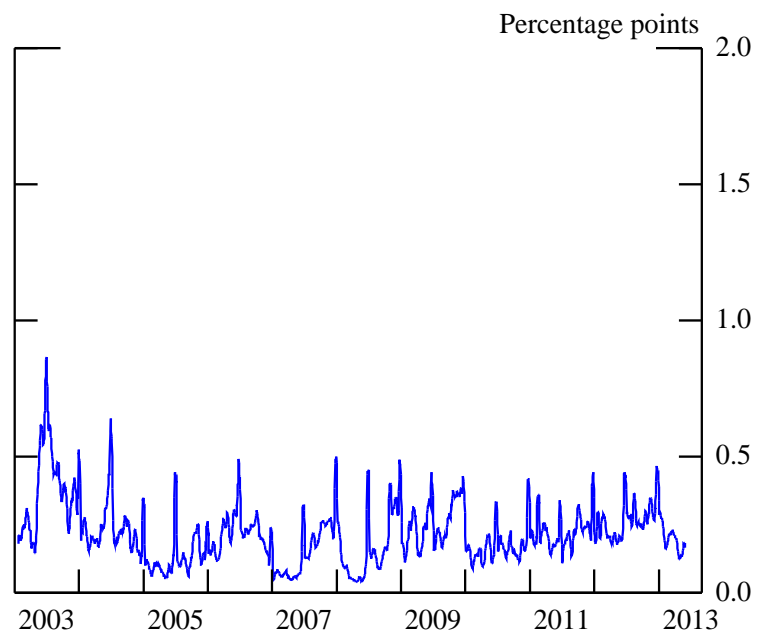

\section{Mexico: Inflation-Indexed Bonds}

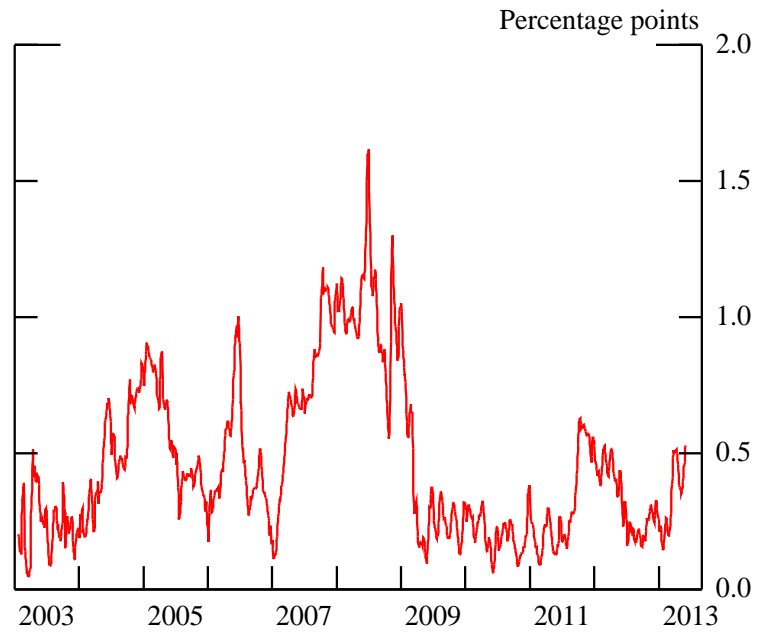

Notes: The figure presents indicators of the bond price fitting error when constructing zero-coupon curves from prices of nominal and inflation-linked sovereign bonds for Brazil (the-left-hand-side panels) and Mexico (the right-hand-side panels) using the Nelson and Siegel (1987) model. Panels A and B display the aggregate fitting error for prices of nominal bonds, defined as the sum of the absolute values of relative price fitting errors (with the relative price fitting error computed as [(fitted price - observed price)/fitted price], and expressed in percentage points) for all bonds with residual maturities between two and ten years. Panels $\mathrm{C}$ and $\mathrm{D}$ display the bond price fitting errors for inflation-indexed bonds. All lines shown are two-week rolling averages of daily absolute fitting errors. 
Figure 7: ZERO-COUPON YIELD AND INFLATION COMPENSATION ESTIMATES

A. 1-Year Forward Nominal Rate Ending in 7 Years (Brazil and Mexico) or 10 Years (Chile)

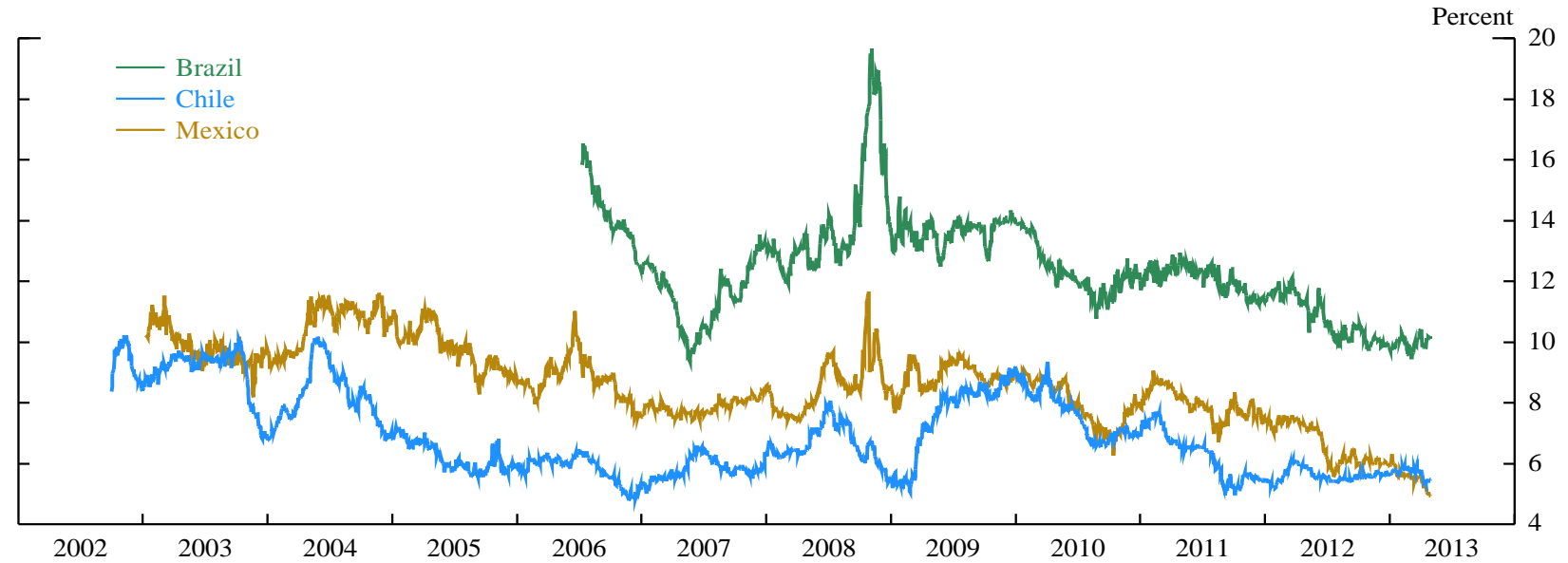

B. 1-Year Forward Real Rate Ending in 7 Years (Brazil and Mexico) or 10 Years (Chile)

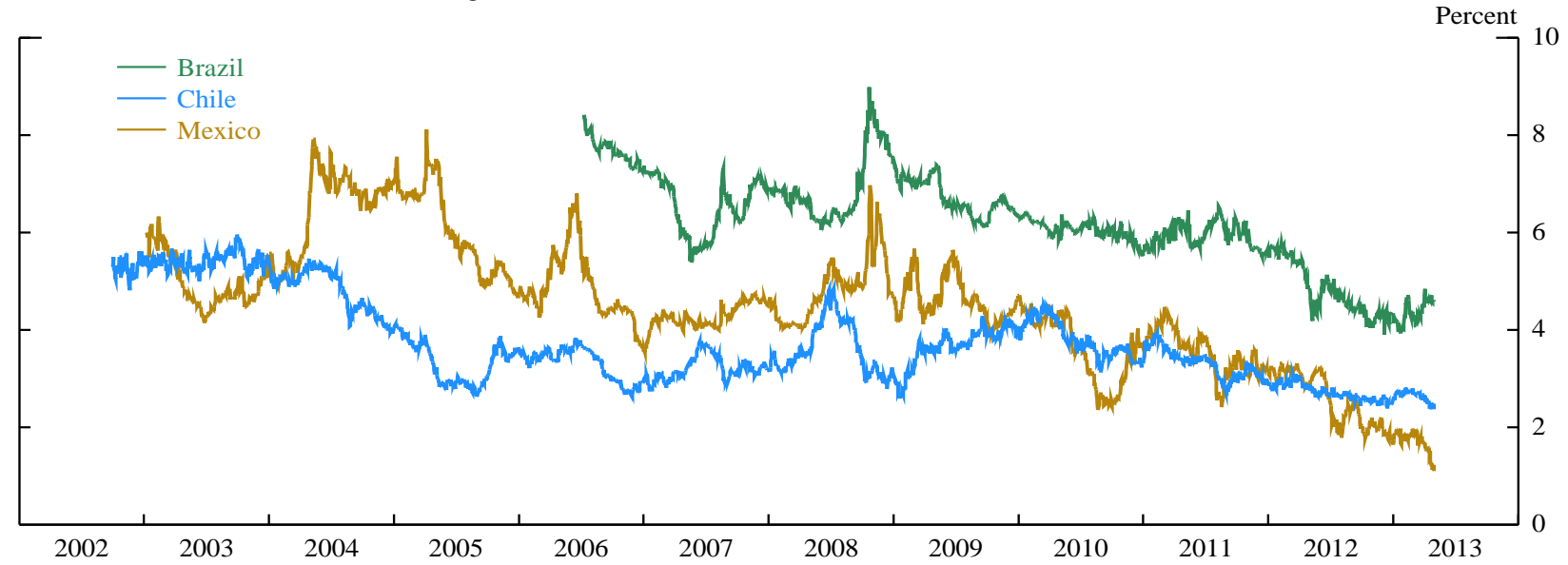

C. 1-Year Forward Inflation Compensation Ending in 7 Years (Brazil and Mexico) or 10 Years (Chile)

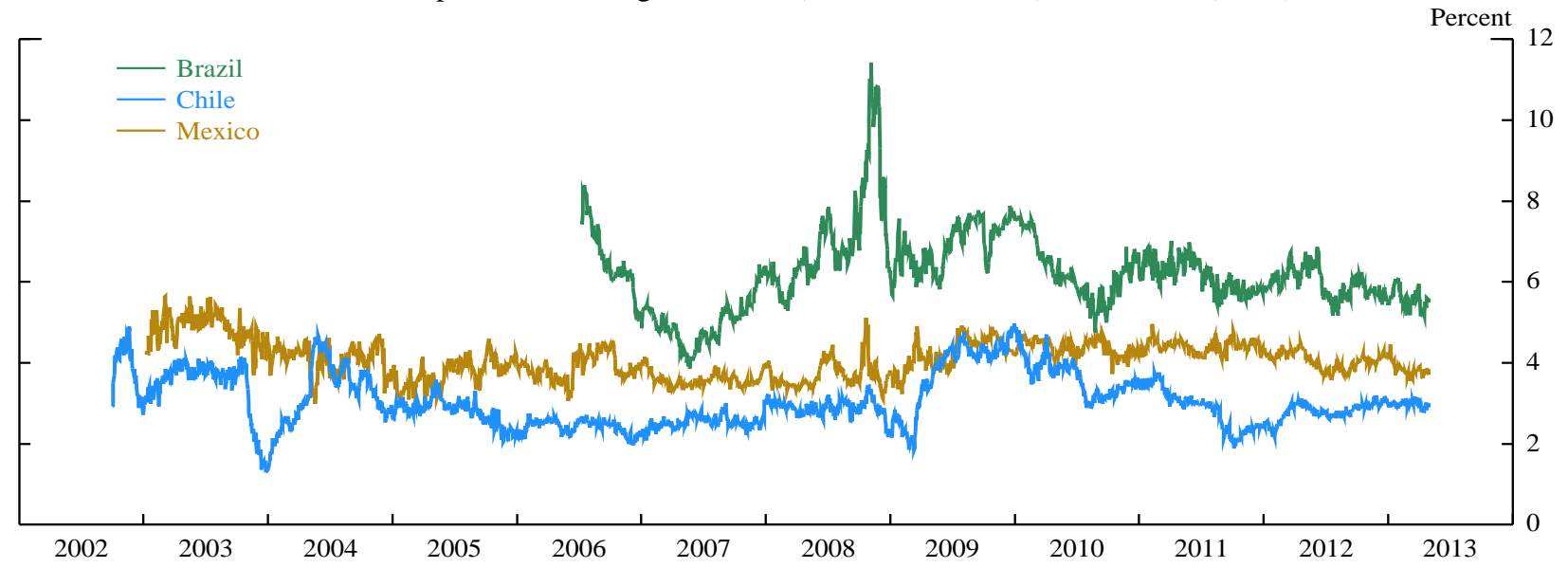

Notes: The figure presents our daily time-series estimates of 1-year nominal (Panel A), real (Panel B), and inflation compensation (Panel C) forward rates, ending in 7 years (for Brazil and Mexico) or 10 years (for Chile). The estimates are derived from our estimated daily nominal and real zero-coupon curves, which we fit from prices on outstanding nominal and inflation-indexed sovereign bonds using the Nelson and Siegel (1987) model. The sample period begins on July 7, 2006 for Brazil, on October 2, 2002 for Chile, and on January 10, 2003 for Mexico, and ends on April 30, 2013. 
Figure 8: BRAZIL: OLS And Influence Plots Per Individual Surprise
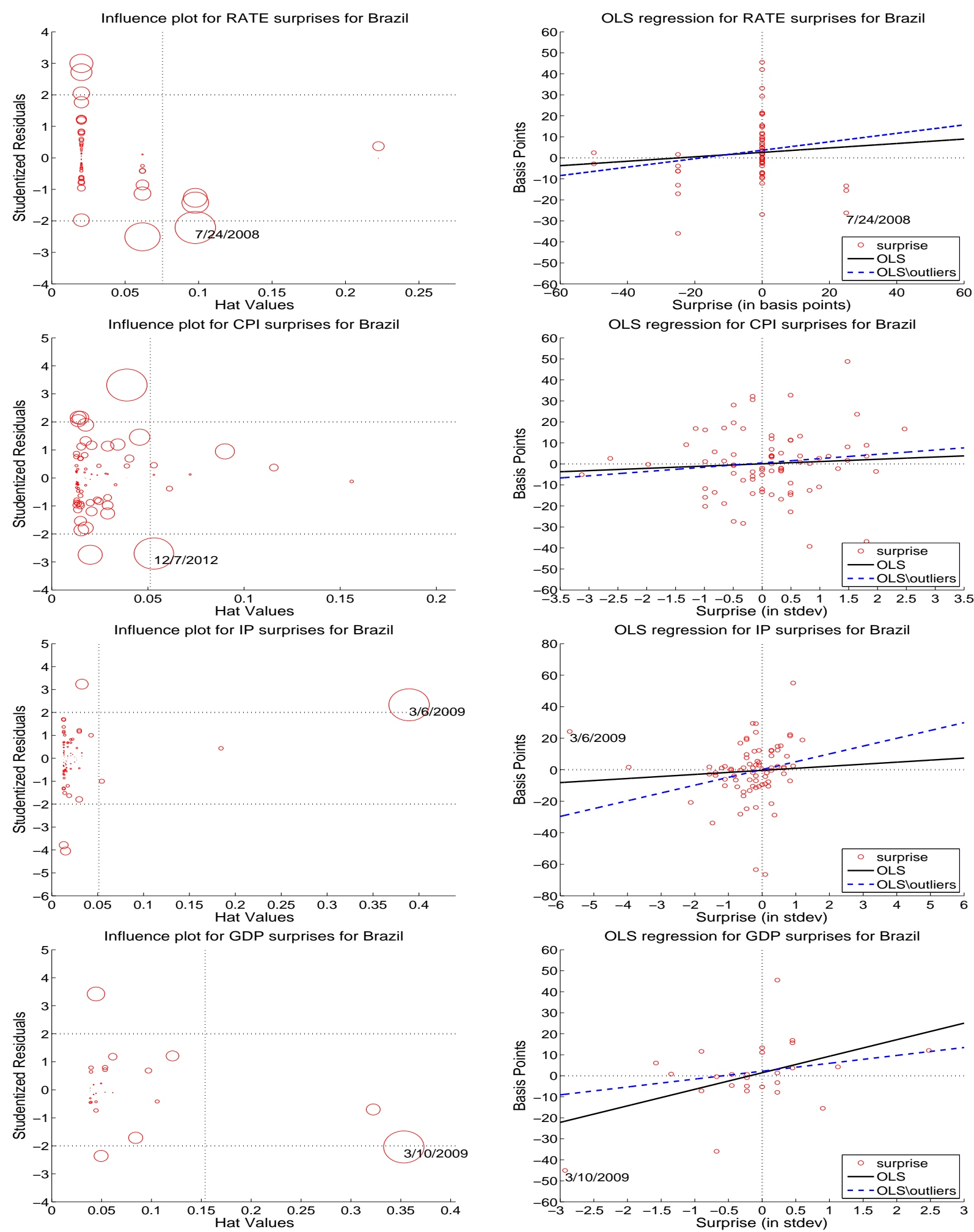

Notes: The left-hand-side panels show influence plots when regressing far-forward inflation compensation on individual macro surprises for Brazil for the full sample period July 2006 - April 2013. Hat-values are shown on the horizontal axis, studentized residuals on the vertical axis, and the radius of each circle is proportional to the relative size of observations' Cook's distance. The horizontal dashed lines are $+/-2$ critical values for studentized residuals, while the vertical dashed line is the critical value for the hat value, set at $4 / N$ with $N$ the number of observations in the single regression. Observations labeled with their release date are marked as outliers. The right-hand side panels show the scatterplot of far-forward inflation compensation vs. surprises, and the single-regression lines using all observations (the solid black lines) and without outliers (the dashed blue lines). 
Figure 9: CHILE: OLS and Influence Plots Per Individual Surprise
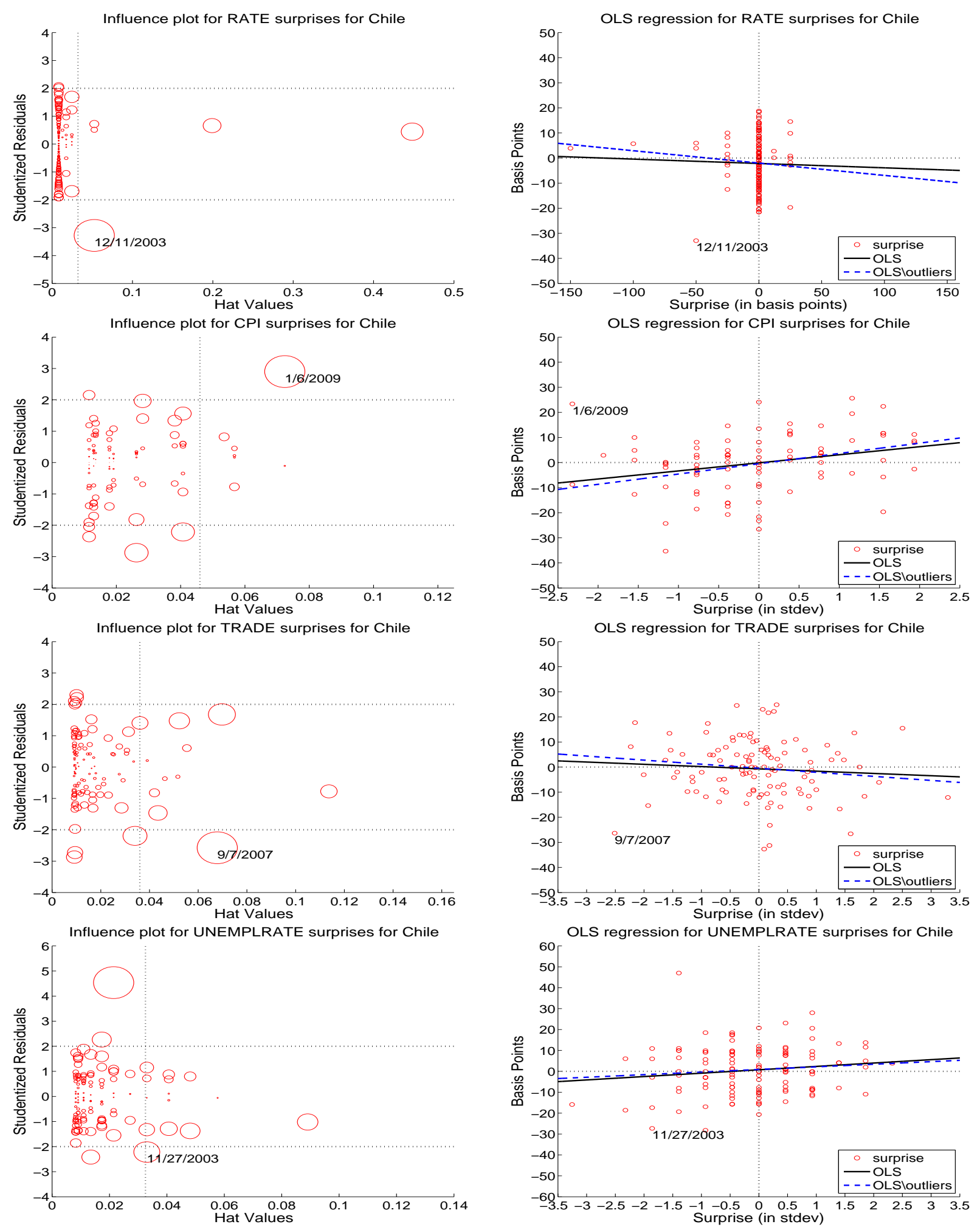

Notes: The left-hand-side panels show influence plots for the regression of far-forward inflation compensation on individual macro surprises for Chile for the full sample period October 2002 - April 2013. See the notes to Figure 8 for further details. 
Figure 10: MEXICO: OLS and Influence Plots Per Individual Surprise
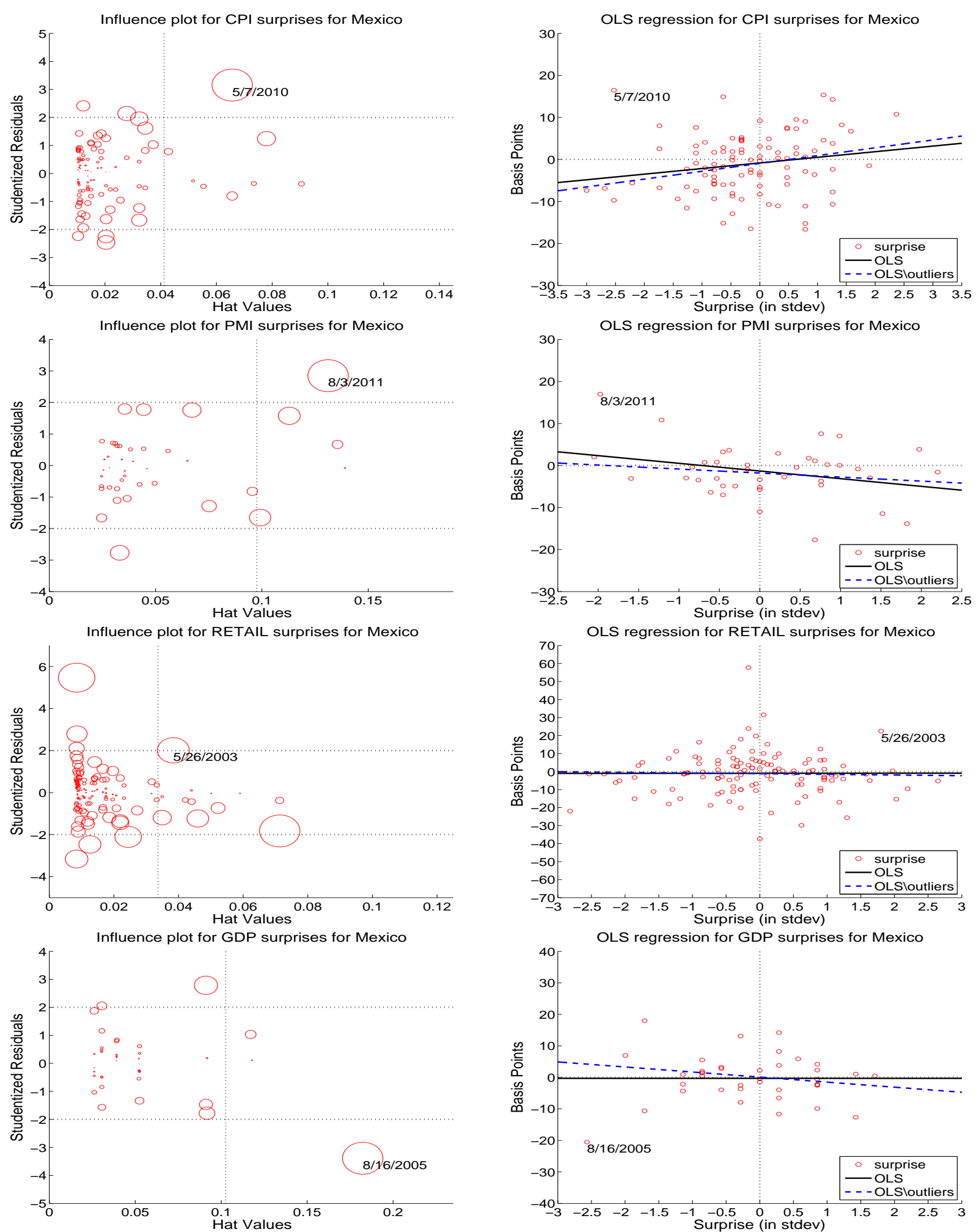

Notes: The left-hand-side panels show influence plots for the regression of far-forward inflation compensation on individual macro surprises for Mexico for the full sample period January 2003 - April 2013. See the notes to Figure 8 for further details. 


\section{Appendix A: Sensitivity Analysis}

In this Appendix we briefly discuss the results of several alternative specifications of our baseline regressions to assess the robustness of our results. Tables A.1 - A.3 show results for five alternative specifications: (i) including the outliers that we identified in Section 4.3, (ii) including the fourth quarter of 2008 in the sample, (iii) including all days in the regressions instead of just those days on which at least one macro figure is released, (iv) dropping the annual dummy from the regression, (v) incorporating the daily change in the 3-month local Treasury Bill rate instead of incorporating surprises in the policy rate directly, as some authors have argued that the one-day change in the treasury bill rates are a better measure of monetary policy surprises, and (vi) including the control variables that we discussed in Section 4.2. In the first column of each table, we repeat our baseline results (in bold) for far-forward inflation compensation from Tables $1-3$.

The second column shows that including outliers does not materially change our baseline results, with the exception of Brazil for which including the outliers makes the coefficient on IP insignificant, while making the coefficient on GDP significant, as discussed in Section 4.3. Furthermore, the third column in Table A.1 shows the impact of including the fourth quarter of 2008 for Brazil, which makes the Wald test statistic much higher, now easily rejecting the null hypothesis that macro surprises do not significantly affect inflation compensation. The reason behind this is that because of the additional variation in inflation compensation during the fourth quarter of 2008, the earlieridentified GDP outlier of March 10, 2009 is now no longer deemed an outlier, which makes the GDP coefficient highly significant, and the Wald statistic high. The fourth column in each table shows that whether we include just days with announcements or all days in the sample, with the latter choice introducing a lot of zero observations, makes very little difference for the results. Dropping the yearly dummy, using policy rate surprises based on daily changes in treasury bill rates, and including various control variables also does not change the baseline results.

Overall, our baseline results prove to be very robust against each of the alternatives we consider, with joint Wald statistics and coefficients on individual news surprises that are little changed.

\section{Appendix B: Rolling Regression Results}

In this section we present subsample analysis results using 5-year rolling regression windows to analyze parameter stability and to assess the effect of the financial crisis on the anchoring of inflation expectations in Brazil, Chile, and Mexico in somewhat more detail. Figure B.1 present results of this analysis. The left-hand-side panels in this figure present the Wald statistic and its $p$-value from estimating equation (3) in the main text using 5 -year rolling windows, the blue and red lines, respectively, while the red lines in the right-hand-side panels show the $t$-statistics of the domestic news surprise that was "most significant" in our baseline results for each individual country: IP for Brazil and CPI for Chile and Mexico.

For Chile, most of the 5-year samples have a $p$-value below $10 \%$ and the rejection of the null for the full sample seems to be driven therefore by the consistently significant response of inflation compensation to news surprises throughout most of the sample. Of note, however, for the estimation samples ending in the most recent two years, the Wald statistic and the $t$-statistic of CPI have fallen substantially. For Mexico, the null hypothesis that news surprises do not systematically affect inflation compensation, lies well above $5 \%$ for all subsamples, and Mexican CPI surprises are never significant at the $5 \%$ level.

For Brazil, the rolling regressions results are harder to interpret. Brazil's first 5-year rolling sample ends in 2011 and for most of the samples, the Wald test rejects the null of inflation com- 
pensation not being affected by news, which is different from our baselines results for Brazil. Upon closer inspection, however, it follows that the March 10, 2009 GDP outlier that we identified in the main text is never taken out for any of the rolling windows. This greatly affects the Wald statistic. Similarly, the March 6, 2009 IP outlier is not identified as such between April 2012 and March 2013. Furthermore, the rolling regressions include the fourth quarter of 2008 and, as shown in Appendix A, inflation compensation does react significantly to news surprises if this volatile period is included. Overall therefore, it is difficult to derive clear conclusions from the rolling regression results for Brazil.

Finally, the blue lines in the right-hand-side panels show the $t$-statistic of U.S. nonfarm payrolls when we include U.S. surprises to our baseline regressions. The significance of nonfarm payroll surprises in the full-sample results for Chile and Mexico seems to be primarily due to their impact in earlier samples, although for Chile U.S. payroll surprises were significant in 2011 and have become significant again since the beginning of 2013. 
Table A.1: BRAZIL: Alternative Specifications (Full Sample: Jul-2006 - Apr-2013)

\begin{tabular}{|c|c|c|c|c|c|c|c|}
\hline variable & $\begin{array}{l}\text { basic } \\
\text { model }\end{array}$ & $\begin{array}{l}\text { with } \\
\text { outliers }\end{array}$ & $\begin{array}{l}\text { with } \\
\text { Q4 } 2008\end{array}$ & $\begin{array}{l}\text { with } \\
\text { all obs. }\end{array}$ & $\begin{array}{l}\text { without } \\
\text { yearly } \\
\text { dummy }\end{array}$ & $\begin{array}{l}\text { with } \\
\text { TBill } \\
\text { rate } \\
\end{array}$ & $\begin{array}{l}\text { with } \\
\text { controls }\end{array}$ \\
\hline \multicolumn{8}{|l|}{ Macro News Surprises } \\
\hline POLICY RATE & $\begin{array}{c}0.13 \\
(0.84)\end{array}$ & $\begin{array}{c}0.06 \\
(0.37)\end{array}$ & $\begin{array}{c}0.06 \\
(0.30)\end{array}$ & $\begin{array}{c}0.14 \\
(0.88)\end{array}$ & $\begin{array}{c}0.12 \\
(0.77)\end{array}$ & $\begin{array}{l}- \\
-\end{array}$ & $\begin{array}{c}0.14 \\
(0.87)\end{array}$ \\
\hline 3-MONTH TBILL & - & & - & - & - & $\begin{array}{l}-0.20 \\
(-0.98)\end{array}$ & - \\
\hline CPI & $\begin{array}{c}2.12 \\
(1.08)\end{array}$ & $\begin{array}{c}1.15 \\
(0.59)\end{array}$ & $\begin{array}{c}2.22 \\
(0.97)\end{array}$ & $\begin{array}{c}2.08 \\
(1.09)\end{array}$ & $\begin{array}{c}2.13 \\
(1.09)\end{array}$ & $\begin{array}{c}2.12 \\
(1.08)\end{array}$ & $\begin{array}{c}2.00 \\
(1.04)\end{array}$ \\
\hline IP & $\begin{array}{c}4.84^{* *} \\
(2.13)\end{array}$ & $\begin{array}{c}1.25 \\
(0.69)\end{array}$ & $\begin{array}{l}7.13^{* * *} \\
(2.73)\end{array}$ & $\begin{array}{l}4.96^{* *} \\
(2.25)\end{array}$ & $\begin{array}{l}4.74^{* *} \\
(2.08)\end{array}$ & $\begin{array}{l}4.78^{* *} \\
(2.10)\end{array}$ & $\begin{array}{l}4.70^{* *} \\
(2.09)\end{array}$ \\
\hline PMI & - & & $\begin{array}{l}- \\
-\end{array}$ & - & - & - & - \\
\hline RETAIL SALES & $\begin{array}{c}2.17 \\
(1.20)\end{array}$ & $\begin{array}{c}2.24 \\
(1.22)\end{array}$ & $\begin{array}{c}2.49 \\
(1.18)\end{array}$ & $\begin{array}{c}2.11 \\
(1.20)\end{array}$ & $\begin{array}{c}2.20 \\
(1.21)\end{array}$ & $\begin{array}{c}2.18 \\
(1.21)\end{array}$ & $\begin{array}{c}2.37 \\
(1.32)\end{array}$ \\
\hline TRADE BALANCE & $\begin{array}{c}3.25 \\
(1.53)\end{array}$ & $\begin{array}{c}3.04 \\
(1.41)\end{array}$ & $\begin{array}{l}1.92 \\
(0.77)\end{array}$ & $\begin{array}{c}1.96 \\
(1.07)\end{array}$ & $\begin{array}{c}1.19 \\
(0.65)\end{array}$ & $\begin{array}{c}3.01 \\
(1.42)\end{array}$ & $\begin{array}{c}1.72 \\
(0.81)\end{array}$ \\
\hline GDP & $\begin{array}{c}3.19 \\
(0.79)\end{array}$ & $\begin{array}{l}7.34^{* *} \\
(2.20)\end{array}$ & $\begin{array}{l}10.12^{\text {*** }} \\
(2.68)\end{array}$ & $\begin{array}{c}3.35 \\
(0.85)\end{array}$ & $\begin{array}{c}3.40 \\
(0.84)\end{array}$ & $\begin{array}{c}3.51 \\
(0.87)\end{array}$ & $\begin{array}{c}3.63 \\
(0.92)\end{array}$ \\
\hline UNEMPL. RATE & $\begin{array}{c}-1.17 \\
(-0.65)\end{array}$ & $\begin{array}{l}-1.33 \\
(-0.73)\end{array}$ & $\begin{array}{l}-0.48 \\
(-0.23)\end{array}$ & $\begin{array}{l}-1.06 \\
(-0.61)\end{array}$ & $\begin{array}{l}-1.22 \\
(-0.68)\end{array}$ & $\begin{array}{l}-1.26 \\
(-0.71)\end{array}$ & $\begin{array}{l}-1.04 \\
(-0.59)\end{array}$ \\
\hline \multicolumn{8}{|l|}{$\underline{\text { Controls }}$} \\
\hline OIL FUTURES & - & - & - & - & - & - & -0.14 \\
\hline FOOD FUTURES & - & $\begin{array}{l}- \\
-\end{array}$ & $\begin{array}{l}- \\
-\end{array}$ & $\begin{array}{l}- \\
-\end{array}$ & $\begin{array}{l}- \\
-\end{array}$ & $\begin{array}{l}- \\
-\end{array}$ & $\begin{array}{l}(-0.25) \\
-0.09\end{array}$ \\
\hline VIX & $\begin{array}{l}- \\
- \\
-\end{array}$ & $\begin{array}{l}- \\
- \\
-\end{array}$ & $\begin{array}{l}- \\
- \\
-\end{array}$ & $\begin{array}{l}- \\
- \\
-\end{array}$ & $\begin{array}{l}- \\
- \\
-\end{array}$ & $\begin{array}{l}- \\
- \\
-\end{array}$ & $\begin{array}{c}(-0.14) \\
0.43 \\
(0.77)\end{array}$ \\
\hline $\begin{array}{l}\text { Number of obs. } \\
R^{2} \\
\text { adj. } R^{2}\end{array}$ & $\begin{array}{l}424 \\
3 \% \\
1 \%\end{array}$ & $\begin{array}{l}428 \\
3 \% \\
1 \%\end{array}$ & $\begin{array}{l}443 \\
4 \% \\
2 \%\end{array}$ & $\begin{array}{c}1706 \\
1 \% \\
0 \%\end{array}$ & $\begin{array}{l}424 \\
2 \% \\
1 \%\end{array}$ & $\begin{array}{l}425 \\
3 \% \\
1 \%\end{array}$ & $\begin{array}{l}420 \\
3 \% \\
1 \%\end{array}$ \\
\hline $\begin{array}{l}\text { Wald-statistic } \\
(p \text {-value })\end{array}$ & $\begin{array}{l}11.17 \\
(0.13) \\
\end{array}$ & $\begin{array}{l}10.01 \\
(0.19) \\
\end{array}$ & $\begin{array}{l}17.84 \\
(0.01) \\
\end{array}$ & $\begin{array}{l}10.58 \\
(0.16) \\
\end{array}$ & $\begin{array}{c}9.14 \\
(0.24) \\
\end{array}$ & $\begin{array}{l}11.47 \\
(0.12) \\
\end{array}$ & $\begin{array}{c}9.62 \\
(0.21) \\
\end{array}$ \\
\hline
\end{tabular}

Notes: The table shows regression results for the full sample period July 2006 - April 2013 for Brazil, for our benchmark model (first column) as well as for a number of alternative specifications (the remaining columns); (i) without correcting for outliers (the only column in the table where outliers are included are the regression), (ii) including observations from the fourth quarter of 2008, (iii) including all observations during our sample period (thus including days on which no Brazilian macroeconomic figures are released), (iv) without including the dummy that takes on the value of one on the first business day of the year, (v) including the daily change in the 3-month local Treasury Bill instead of the standardized surprise component of the policy rate, and (vi) including the 12-month oil futures, 3-month food futures and the VIX as control variables in the regression. Oil and food futures are recorded as the change from the day before, in basis points, while the VIX is recorded as the change from the day before in percentage points. See the notes to Table 1 in the main text for further details. 
Table A.2: Chile: Alternative Specifications (Full Sample: Oct-2002 - Apr-2013)

\begin{tabular}{|c|c|c|c|c|c|c|c|}
\hline variable & $\begin{array}{l}\text { basic } \\
\text { model }\end{array}$ & $\begin{array}{l}\text { with } \\
\text { outliers }\end{array}$ & $\begin{array}{l}\text { with } \\
\text { Q4 } 2008\end{array}$ & $\begin{array}{l}\text { with } \\
\text { all obs. }\end{array}$ & $\begin{array}{l}\text { without } \\
\text { yearly } \\
\text { dummy }\end{array}$ & $\begin{array}{l}\text { with } \\
\text { TBill } \\
\text { rate }\end{array}$ & $\begin{array}{l}\text { with } \\
\text { controls }\end{array}$ \\
\hline \multicolumn{8}{|l|}{ Macro News Surprises } \\
\hline POLICY RATE & $\begin{array}{c}-0.04 \\
(-0.71)\end{array}$ & $\begin{array}{c}0.00 \\
(0.03)\end{array}$ & $\begin{array}{l}-0.04 \\
(-0.72)\end{array}$ & $\begin{array}{c}-0.04 \\
(-0.72)\end{array}$ & $\begin{array}{l}-0.04 \\
(-0.83)\end{array}$ & $\begin{array}{l}- \\
-\end{array}$ & $\begin{array}{l}-0.04 \\
(-0.81)\end{array}$ \\
\hline 3-MONTH TBILL & - & & $\begin{array}{l}- \\
-\end{array}$ & $\begin{array}{l}- \\
-\end{array}$ & $\begin{array}{l}- \\
-\end{array}$ & $\begin{array}{c}-0.16 \\
(-1.24)\end{array}$ & $\begin{array}{l}- \\
-\end{array}$ \\
\hline CPI & $\begin{array}{l}3.94^{* * *} \\
(3.31)\end{array}$ & $\begin{array}{c}3.12^{* * *} \\
(2.65)\end{array}$ & $\begin{array}{l}3.76^{* * *} \\
(3.22)\end{array}$ & $\begin{array}{l}4.12^{* * *} \\
(3.30)\end{array}$ & $\begin{array}{l}4.12^{* * *} \\
(3.49)\end{array}$ & $\begin{array}{l}3.89^{* * *} \\
(3.25)\end{array}$ & $\begin{array}{l}4.03^{* * *} \\
(3.38)\end{array}$ \\
\hline IP & $\begin{array}{l}-1.13 \\
(-1.09)\end{array}$ & $\begin{array}{l}-1.15 \\
(-1.08)\end{array}$ & $\begin{array}{l}-1.00 \\
(-0.97)\end{array}$ & $\begin{array}{c}-1.01 \\
(-0.92)\end{array}$ & $\begin{array}{c}-1.11 \\
(-1.07)\end{array}$ & $\begin{array}{l}-1.15 \\
(-1.10)\end{array}$ & $\begin{array}{l}-1.20 \\
(-1.15)\end{array}$ \\
\hline PMI & - & & - & - & - & - & - \\
\hline RETAIL SALES & $\begin{array}{c}1.42 \\
(0.67)\end{array}$ & $\begin{array}{c}1.50 \\
(0.69)\end{array}$ & $\begin{array}{c}1.52 \\
(0.72)\end{array}$ & $\begin{array}{c}1.31 \\
(0.59)\end{array}$ & $\begin{array}{c}1.40 \\
(0.66)\end{array}$ & $\begin{array}{c}1.43 \\
(0.67)\end{array}$ & $\begin{array}{c}1.31 \\
(0.62)\end{array}$ \\
\hline TRADE BALANCE & $\begin{array}{c}-1.85^{*} \\
(-1.71)\end{array}$ & $\begin{array}{l}-1.26 \\
(-1.16)\end{array}$ & $\begin{array}{l}-1.96^{*} \\
(-1.89)\end{array}$ & $\begin{array}{l}-1.61 \\
(-1.43)\end{array}$ & $\begin{array}{l}-1.61 \\
(-1.52)\end{array}$ & $\begin{array}{l}-1.90^{*} \\
(-1.75)\end{array}$ & $\begin{array}{l}-1.88^{*} \\
(-1.74)\end{array}$ \\
\hline GDP & $\begin{array}{c}3.04^{*} \\
(1.71)\end{array}$ & $\begin{array}{c}3.05^{*} \\
(1.67)\end{array}$ & $\begin{array}{c}2.94^{*} \\
(1.65)\end{array}$ & $\begin{array}{c}2.97 \\
(1.58)\end{array}$ & $\begin{array}{c}3.02^{*} \\
(1.70)\end{array}$ & $\begin{array}{r}3.07^{*} \\
(1.72)\end{array}$ & $\begin{array}{c}3.05^{*} \\
(1.70)\end{array}$ \\
\hline UNEMPL. RATE & $\begin{array}{c}1.12 \\
(1.15)\end{array}$ & $\begin{array}{c}1.48 \\
(1.50)\end{array}$ & $\begin{array}{c}1.45 \\
(1.54)\end{array}$ & $\begin{array}{c}1.18 \\
(1.15)\end{array}$ & $\begin{array}{c}1.13 \\
(1.16)\end{array}$ & $\begin{array}{c}1.11 \\
(1.13)\end{array}$ & $\begin{array}{c}1.10 \\
(1.13)\end{array}$ \\
\hline \multicolumn{8}{|l|}{ Controls } \\
\hline OIL FUTURES & - & & - & - & - & - & $\begin{array}{l}-0.06 \\
(-019)\end{array}$ \\
\hline FOOD FUTURES & $\begin{array}{l}- \\
-\end{array}$ & & - & $\begin{array}{l}- \\
-\end{array}$ & - & - & $\begin{array}{c}0.19 \\
(0.46)\end{array}$ \\
\hline VIX & - & & $\begin{array}{l}- \\
-\end{array}$ & - & $\begin{array}{l}- \\
-\end{array}$ & $\begin{array}{l}- \\
-\end{array}$ & $\begin{array}{c}0.24 \\
(0.75)\end{array}$ \\
\hline $\begin{array}{l}\text { Number of obs. } \\
R^{2} \\
\text { adj. } R^{2}\end{array}$ & $\begin{array}{l}481 \\
5 \% \\
3 \%\end{array}$ & $\begin{array}{l}485 \\
4 \% \\
2 \%\end{array}$ & $\begin{array}{l}495 \\
5 \% \\
3 \%\end{array}$ & $\begin{array}{c}2690 \\
1 \% \\
0 \%\end{array}$ & $\begin{array}{l}481 \\
4 \% \\
3 \%\end{array}$ & $\begin{array}{l}481 \\
5 \% \\
3 \%\end{array}$ & $\begin{array}{l}480 \\
5 \% \\
3 \%\end{array}$ \\
\hline $\begin{array}{l}\text { Wald-statistic } \\
\text { ( } p \text {-value) }\end{array}$ & $\begin{array}{l}20.45 \\
(0.01)\end{array}$ & $\begin{array}{l}15.15 \\
(0.03)\end{array}$ & $\begin{array}{l}21.22 \\
(0.00)\end{array}$ & $\begin{array}{l}18.42 \\
(0.01)\end{array}$ & $\begin{array}{l}20.89 \\
(0.00)\end{array}$ & $\begin{array}{l}21.27 \\
(0.00)\end{array}$ & $\begin{array}{l}21.04 \\
(0.00)\end{array}$ \\
\hline
\end{tabular}

Notes: The table shows regression results for the baseline model as well as several alternative specifications for the full sample period October 2002 - April 2013 for Chile. See the notes to Table A.1 and to Table 1 in the main text for further details. 
Table A.3: MeXiCO: Alternative Specifications (Full Sample: Jan-2003 - Apr-2013)

\begin{tabular}{|c|c|c|c|c|c|c|c|}
\hline variable & $\begin{array}{l}\text { basic } \\
\text { model }\end{array}$ & $\begin{array}{l}\text { with } \\
\text { outliers }\end{array}$ & $\begin{array}{l}\text { with } \\
\text { Q4 } 2008\end{array}$ & $\begin{array}{l}\text { with } \\
\text { all obs. }\end{array}$ & $\begin{array}{l}\text { without } \\
\text { yearly } \\
\text { dummy }\end{array}$ & $\begin{array}{l}\text { with } \\
\text { TBill } \\
\text { rate }\end{array}$ & $\begin{array}{l}\text { with } \\
\text { controls }\end{array}$ \\
\hline \multicolumn{8}{|l|}{ Macro News Surprises } \\
\hline POLICY RATE & $\begin{array}{c}-0.16 \\
(-1.48)\end{array}$ & $\begin{array}{l}-0.15 \\
(-1.46)\end{array}$ & $\begin{array}{l}-0.16 \\
(-1.48)\end{array}$ & $\begin{array}{c}-0.15 \\
(-1.36)\end{array}$ & $\begin{array}{l}-0.16 \\
(-1.48)\end{array}$ & - & $\begin{array}{l}-0.16 \\
(-1.59)\end{array}$ \\
\hline 3-MONTH TBILL & - & & - & - & - & $\begin{array}{c}-0.07 \\
(-0.34)\end{array}$ & $\begin{array}{l}- \\
-\end{array}$ \\
\hline CPI & $\begin{array}{c}2.03^{*} \\
(1.94)\end{array}$ & $\begin{array}{c}1.49 \\
(1.46)\end{array}$ & $\begin{array}{c}1.94^{*} \\
(1.85)\end{array}$ & $\begin{array}{c}2.03^{*} \\
(1.82)\end{array}$ & $\begin{array}{c}1.98^{*} \\
(1.90)\end{array}$ & $\begin{array}{c}2.01^{*} \\
(1.95)\end{array}$ & $\begin{array}{l}1.99^{* *} \\
(2.02)\end{array}$ \\
\hline IP & $\begin{array}{c}1.59^{*} \\
(1.74)\end{array}$ & $\begin{array}{l}1.60^{*} \\
(1.73)\end{array}$ & $\begin{array}{r}1.60^{*} \\
(1.75)\end{array}$ & $\begin{array}{r}1.65^{*} \\
(1.69)\end{array}$ & $\begin{array}{r}1.59^{*} \\
(1.74)\end{array}$ & $\begin{array}{c}1.54^{*} \\
(1.71)\end{array}$ & $\begin{array}{l}1.73^{* *} \\
(1.98)\end{array}$ \\
\hline PMI & $\begin{array}{c}-1.15 \\
(-0.68)\end{array}$ & $\begin{array}{l}-1.89 \\
(-1.17)\end{array}$ & $\begin{array}{l}-1.14 \\
(-0.67)\end{array}$ & $\begin{array}{l}-1.24 \\
(-0.69)\end{array}$ & $\begin{array}{l}-1.19 \\
(-0.71)\end{array}$ & $\begin{array}{l}-1.13 \\
(-0.68)\end{array}$ & $\begin{array}{l}-1.09 \\
(-0.69)\end{array}$ \\
\hline RETAIL SALES & $\begin{array}{c}-0.28 \\
(-0.29)\end{array}$ & $\begin{array}{c}0.08 \\
(0.09)\end{array}$ & $\begin{array}{c}0.55 \\
(0.60)\end{array}$ & $\begin{array}{c}-0.24 \\
(-0.24)\end{array}$ & $\begin{array}{l}-0.27 \\
(-0.29)\end{array}$ & $\begin{array}{l}-0.30 \\
(-0.32)\end{array}$ & $\begin{array}{l}-0.03 \\
(-0.03)\end{array}$ \\
\hline TRADE BALANCE & $\begin{array}{c}-0.60 \\
(-0.63)\end{array}$ & $\begin{array}{l}-0.60 \\
(-0.63)\end{array}$ & $\begin{array}{l}-0.28 \\
(-0.30)\end{array}$ & $\begin{array}{l}-0.63 \\
(-0.62)\end{array}$ & $\begin{array}{l}-0.60 \\
(-0.64)\end{array}$ & $\begin{array}{l}-0.58 \\
(-0.62)\end{array}$ & $\begin{array}{l}-0.59 \\
(-0.67)\end{array}$ \\
\hline GDP & $\begin{array}{c}-1.68 \\
(-0.93)\end{array}$ & $\begin{array}{l}-0.03 \\
(-0.02)\end{array}$ & $\begin{array}{l}-2.11 \\
(-1.18)\end{array}$ & $\begin{array}{l}-1.65 \\
(-0.85)\end{array}$ & $\begin{array}{l}-1.68 \\
(-0.93)\end{array}$ & $\begin{array}{l}-1.67 \\
(-0.94)\end{array}$ & $\begin{array}{l}-1.84 \\
(-1.08)\end{array}$ \\
\hline UNEMPL. RATE & $\begin{array}{c}-0.58 \\
(-0.62)\end{array}$ & $\begin{array}{l}-0.58 \\
(-0.62)\end{array}$ & $\begin{array}{l}-0.37 \\
(-0.40)\end{array}$ & $\begin{array}{l}-0.60 \\
(-0.61)\end{array}$ & $\begin{array}{l}-0.58 \\
(-0.62)\end{array}$ & $\begin{array}{l}-0.54 \\
(-0.59)\end{array}$ & $\begin{array}{l}-0.77 \\
(-0.88)\end{array}$ \\
\hline \multicolumn{8}{|l|}{ Controls } \\
\hline OIL FUTURES & - & & - & - & - & - & -0.15 \\
\hline FOOD FUTURES & $\begin{array}{l}- \\
- \\
-\end{array}$ & & $\begin{array}{l}- \\
- \\
-\end{array}$ & $\begin{array}{l}- \\
- \\
-\end{array}$ & $\begin{array}{l}- \\
- \\
-\end{array}$ & $\begin{array}{l}- \\
- \\
-\end{array}$ & $\begin{array}{c}(-0.57) \\
0.06 \\
(0.20)\end{array}$ \\
\hline VIX & - & & $\begin{array}{l}- \\
-\end{array}$ & - & $\begin{array}{l}- \\
-\end{array}$ & $\begin{array}{l}- \\
-\end{array}$ & $\begin{array}{c}0.37 \\
(1.47)\end{array}$ \\
\hline $\begin{array}{l}\text { Number of obs. } \\
R^{2} \\
\text { adj. } R^{2}\end{array}$ & $\begin{array}{l}678 \\
2 \% \\
0 \%\end{array}$ & $\begin{array}{l}682 \\
1 \% \\
0 \%\end{array}$ & $\begin{array}{l}696 \\
2 \% \\
0 \%\end{array}$ & $\begin{array}{c}2618 \\
0 \% \\
0 \%\end{array}$ & $\begin{array}{l}678 \\
2 \% \\
0 \%\end{array}$ & $\begin{array}{l}677 \\
1 \% \\
0 \%\end{array}$ & $\begin{array}{l}671 \\
2 \% \\
1 \%\end{array}$ \\
\hline $\begin{array}{l}\text { Wald-statistic } \\
(p \text {-value })\end{array}$ & $\begin{array}{l}10.98 \\
(0.20)\end{array}$ & $\begin{array}{c}9.23 \\
(0.32)\end{array}$ & $\begin{array}{l}10.85 \\
(0.21)\end{array}$ & $\begin{array}{c}9.86 \\
(0.28)\end{array}$ & $\begin{array}{l}10.82 \\
(0.21) \\
\end{array}$ & $\begin{array}{c}8.94 \\
(0.35) \\
\end{array}$ & $\begin{array}{l}13.15 \\
(0.11)\end{array}$ \\
\hline
\end{tabular}

Notes: The table shows regression results for the baseline model as well as several alternative specifications for the full sample period January 2003 - April 2013 for Mexico. See the notes to Table A.1 and to Table 1 in the main text for further details. 
Figure B.1: Baseline Model: Rolling Regression Results For Far-Forward Inflation Compensation

A. Brazil: Joint Wald Test

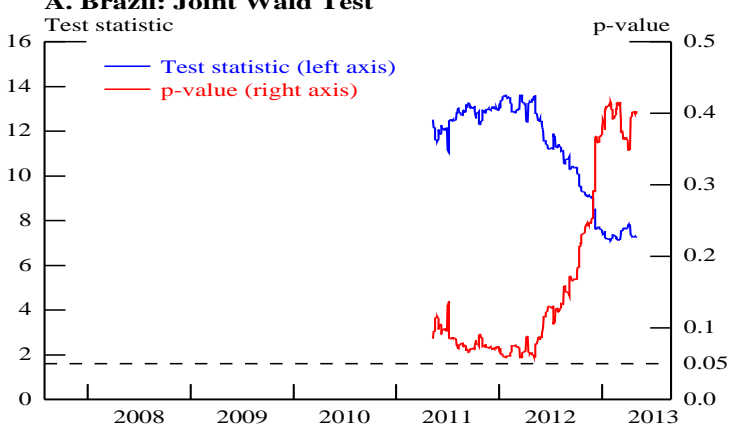

C. Chile: Joint Wald Test

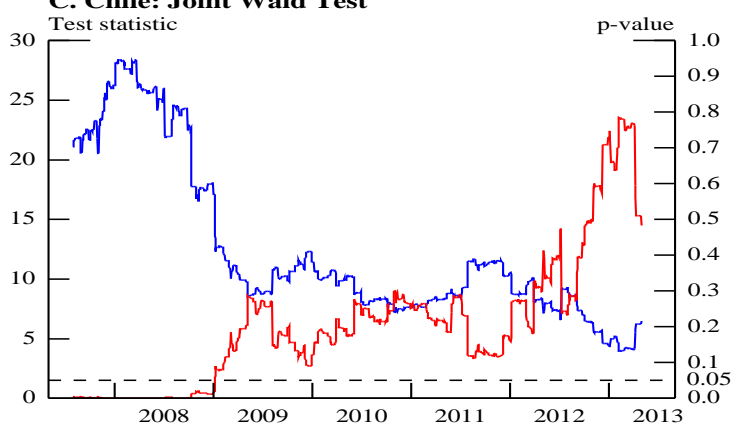

E. Mexico: Joint Wald Test

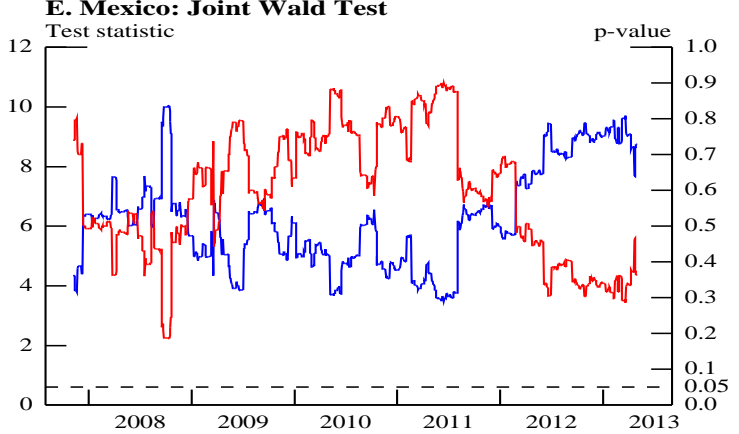

B. Brazil: t-statistics

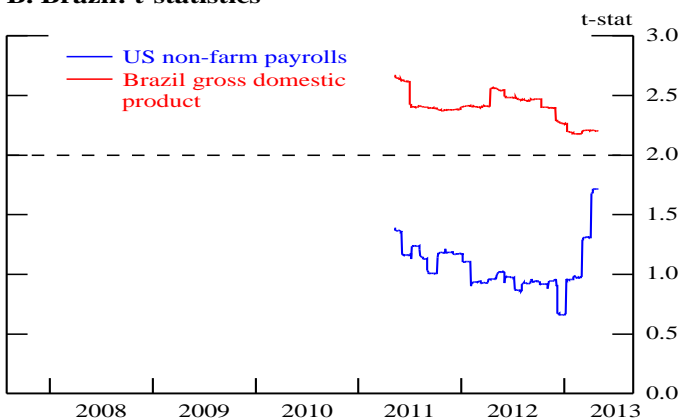

D. Chile: t-statistics

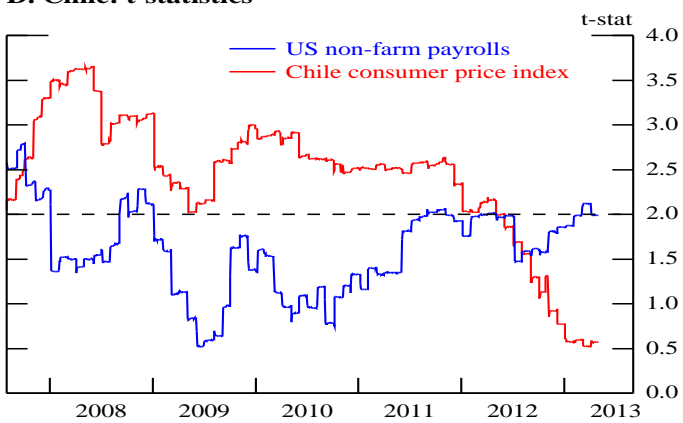

F. Mexico: t-statistics

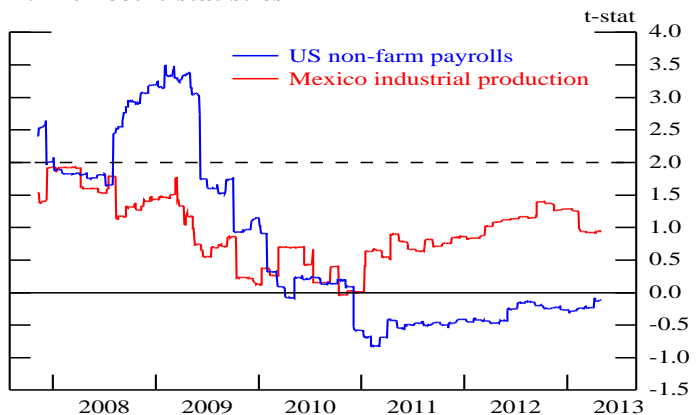

Notes: The figure presents results from our baseline model estimated using rolling regression windows with a length of five calendar years. Reported in the left-hand-side panels are the Wald test statistic and corresponding $p$-value of testing the null hypothesis that all regression coefficients (with the exception of the constant and the yearly dummy) are equal to zero. Reported in the right-hand-side panels are the $t$-statistic for the domestic news surprise that came in "most significant" in the full-sample baseline regression for each country as reported in Tables 1 - 3 in the main text (IP for Brazil and CPI for Chile and Mexico) and for U.S. nonfarm payroll surprises (from the baseline model with U.S. surprises). The dotted lines in the left-hand-side and right-hand-side panels indicate the $5 \%$ significance threshold for $p$-values and $t$-statistics, respectively. 